\title{
THE CREATION AND IMPLEMENTATION OF MĀORI POLICIES
}

\author{
BY \\ Paki Manukau \\ (Aka Vincent Underwood)
}

\begin{abstract}
A thesis
submitted to the Victoria University of Wellington in fulfilment of the requirements for the degree of Master of Social Policy
\end{abstract}

Victoria University of Wellington 


\section{Karakia}

Tō tiakina māramatanga e Atua

Ki tō mātou kīngi Tūheitia

Me te Kāhui Ariki

Me ngā tinana e māuiui ana

Tae noa kia mātou katoa i te rā nei. Āe

Naū te kororia

Naū te kororia

Naū te kororia

Rire, rire hau

\section{Paimārire}

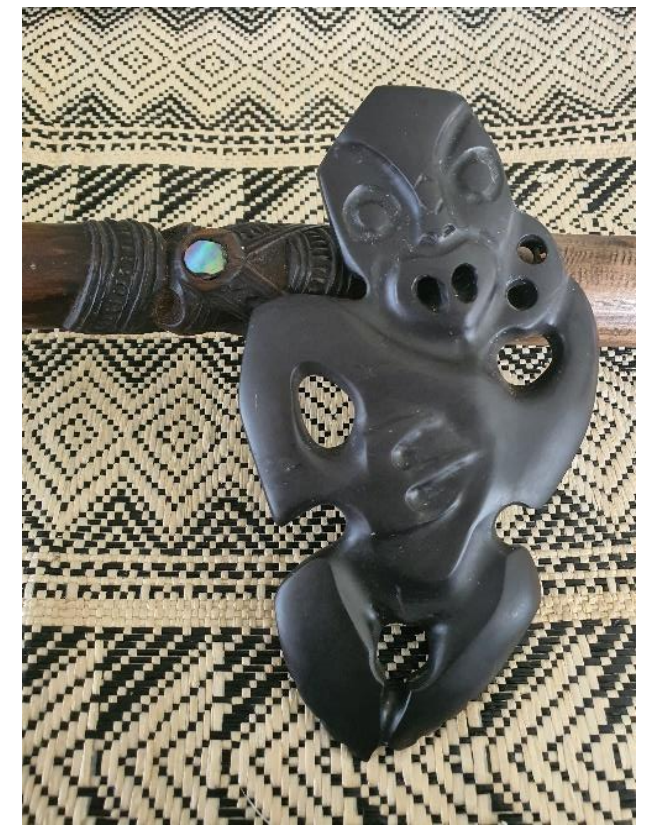




\section{Abstract}

Policy that affects Māori is not new. It has existed since the first Europeans arrived in New Zealand. Some have been created where Māori are external to its development. Some have been developed based on engagement with Māori but have been influenced by a Eurocentric perspective. Yet others have been developed by Māori for Māori.

This thesis presents some of the historical, social, and economic factors that have influenced the need for government and non-government organisations to develop policies that are more responsive to the needs and aspirations of Māori. It will also demonstrate that despite a myriad of policy, legislative, and strategic changes that have progressively shifted towards responsiveness to Māori, not much has been achieved statistically, highlighting a need for policies that are significantly different from that which has already been tried. In the current political climate, we find ourselves in an exciting time where the government is endorsing a more Māori worldview philosophy. One that acknowledges that previous policy, legislative and strategic change, has only been minimally effective. Moreover, one that understands that it is imperative to the wellbeing of Māori and, by extension, the social development of New Zealand to develop new policies that will make a significant and lasting positive change for Māori.

This thesis aims to understand why organisations find it necessary to develop Māori responsive policies and how Māori policy is formulated and implemented in the current political climate. The associated aims are to identify commonalities and best practices in the development of Māori policy and understand what Māori policymaking involves.

This thesis will analyse two examples of Māori policy development and implementation: one from a government agency, the Ministry of Social Development (MSD) and one from a non-governmental organisation, WellStop. MSD and WellStop have proposed to move beyond the perfunctory use of tīkanga and te reo Māori within their organisations and embark on a journey of engagement to embed a Māori worldview, values and processes across the whole of their organisations from leadership to frontline. For MSD, which is one of the largest government organisations in New 
Zealand, this is no small feat, and WellStop, while it is a smaller organisation, is an industry leader for their sector in combating harmful sexual behaviour.

What underpins the process of developing their Māori responsive policies is vitally important. With this in mind, this thesis includes first-hand accounts from Hohepa Patea, the Principal Māori Advisor for MSD, and Mark King, the Chief Executive Officer for WellStop. Their contribution to this thesis has revealed many commonalities in the development of the Māori policies for both organisations. The findings show that while MSD has been influenced to develop policies that are responsive to Māori due to governmental aspirations to address Māori social and economic conditions reflected in negative statistics, WellStop is influenced by the parameters set by the expectations of government organisations, the standards set by Level 2 accreditation (Ministry of Social Development, 2020 (a)), and professional registration bodies (Social Workers Registration Board, n.d. (1); New Zealand Association of Counsellors - Te Roopu Kaiwhiriwhiri o Aotearoa, n.d. (3)). I will elaborate on the similarities in the stages of development in each organisations' policies: the use of whakataukī and karakia, whose inspirational words anchor their policies in mātauranga Māori; the establishment of strong Māori leadership, knowledgeable in mātauranga Māori and tīkanga to ensure the policies' cultural efficacy and to drive the mauri of the policies from the top down; researching each organisations' previous and current policies that pertain to Māori to understand the past and develop more effective policies; and finally, the merit of utilising tīkanga processes when engaging with Māori staff, whānau, hapū and iwi.

What cannot be denied is the influence of Hohepa and Mark's background knowledge of mātauranga Māori and their heart and drive to see their organisations operate from a Te Ao Māori perspective. Regardless of other influences, they intend to make spaces and places better for Māori whānau who access their services. Hohepa and Mark are clear that embedding a Māori worldview and values across their organisations is the primary focus. One of the most crucial common denominators in both organisations' policies is a clear understanding of the importance of keeping people front of mind to ensure that the policies are developed with a powerful sense of manaakitanga and kaitiakitanga.

He aha te mea nui i tenei Āo? Māku e kī atu.

He tangata! He tangata! He tangata!

Nā Meri Ngāroto 


\section{Table of Contents}

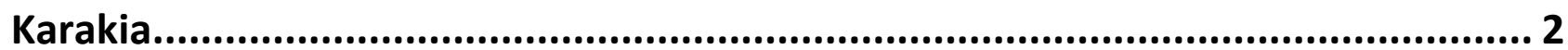

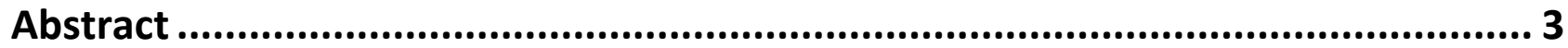

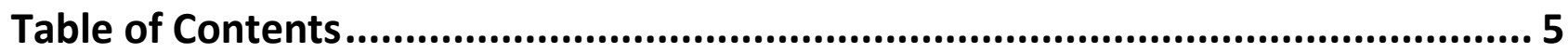

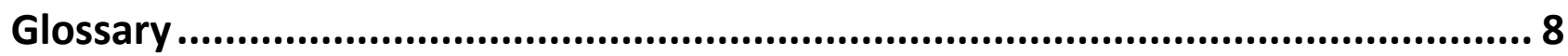

Chapter 1: Introduction ..................................................................................... 13

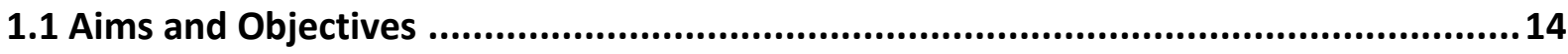

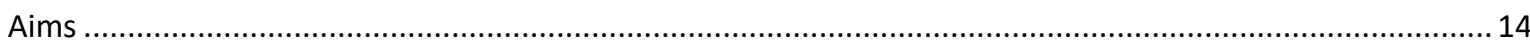

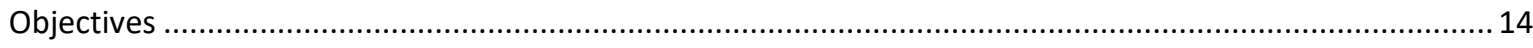

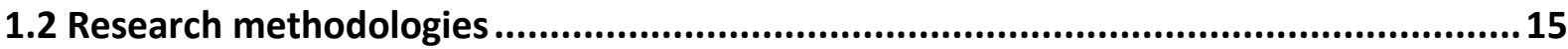

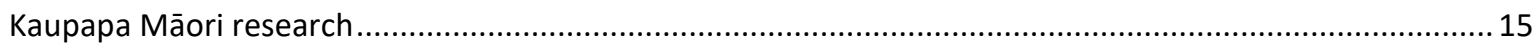

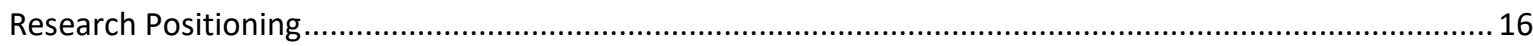

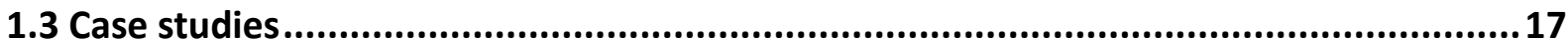

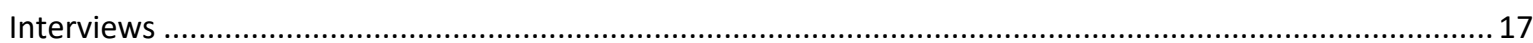

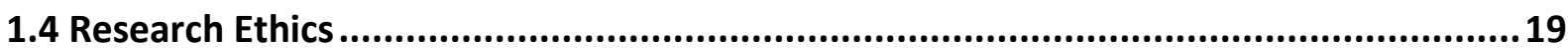

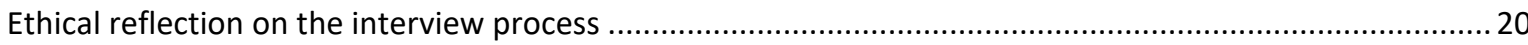

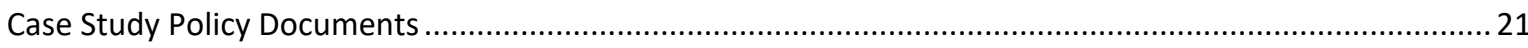

MSD

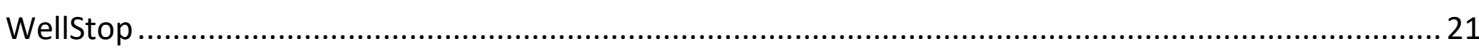

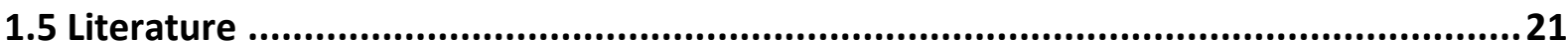

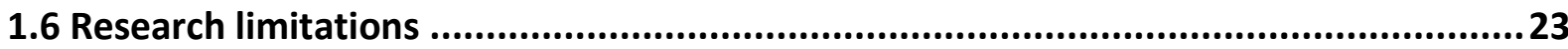

1.7 Thesis Outline

Chapter 2: Historical contributors towards the need for Māori responsive policy 26

2.1 Urbanisation and Neoliberalism ................................................................................27

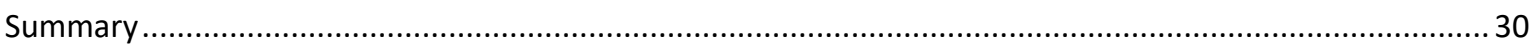

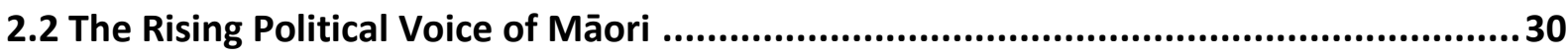

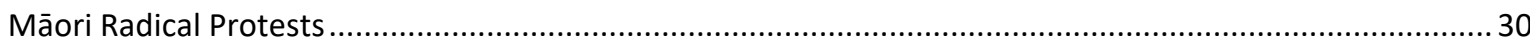

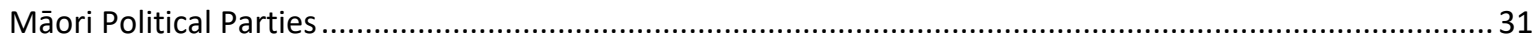

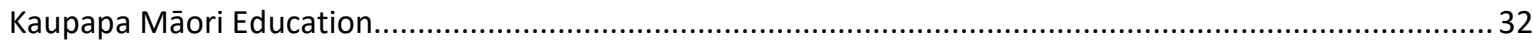

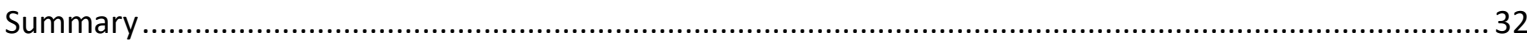

2.3 Historical government policy: Recommendations, legislation and strategies to address

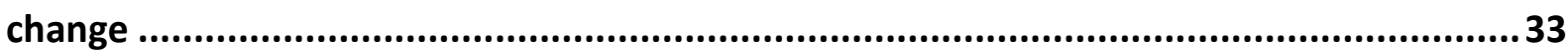

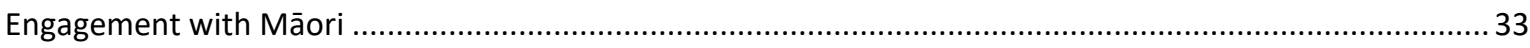

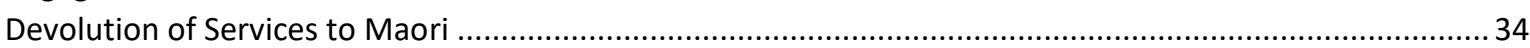

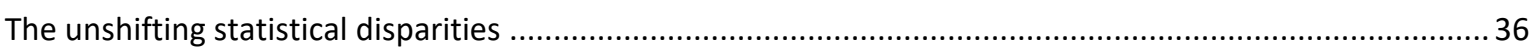

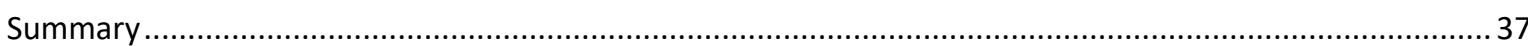

2.4 The current Government's mandate on the development of Māori responsive policy.38

2.5 Conclusion 
Māori should be involved in policy decision-making and leadership

Te Ao Māori engagement processes should be utilised when engaging with Māori ................................... 41

\section{Chapter 3: The Ministry of Social Development .................................................... 43}

3.1 MSD's Tauākī Whakamaunga Atu: Statement of Intent 2018-2022 ............................44

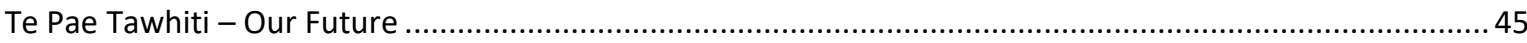

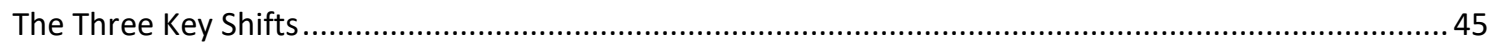

Key Shift One: Mana Manaaki - A positive experience every time ................................................. 45

Key Shift Two: Kotahitanga - Partnering for greater impact...................................................... 46

Key Shift Three: Kia Takatū Tātou - Supporting long-term social and economic development .......... 46 Summary

3.2 Te Pae Tata - Māori Strategy and Action Plan .....................................................49

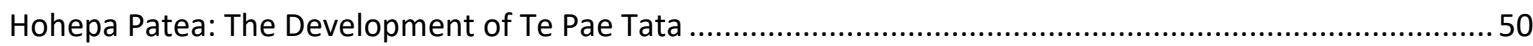

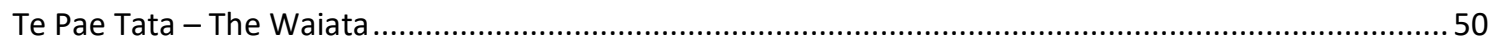

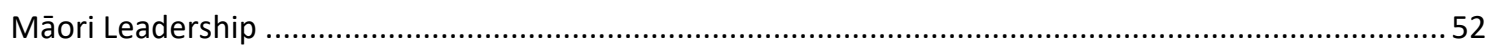

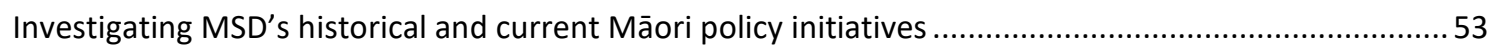

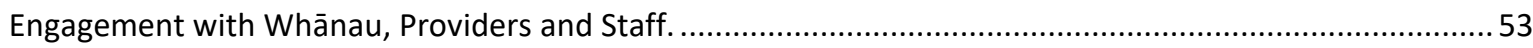

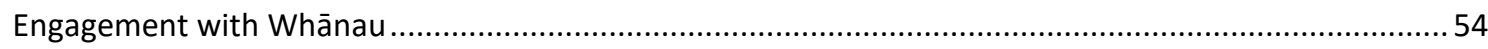

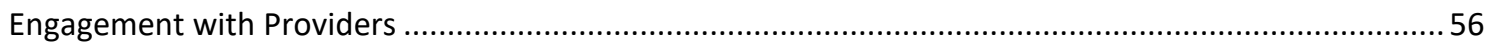

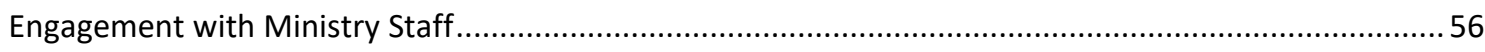

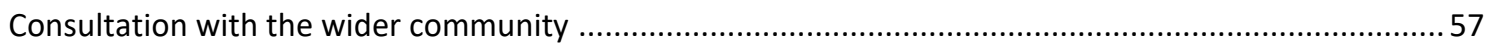

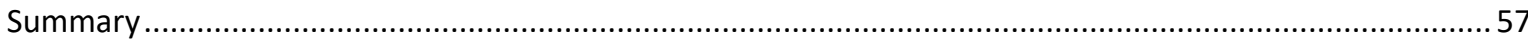

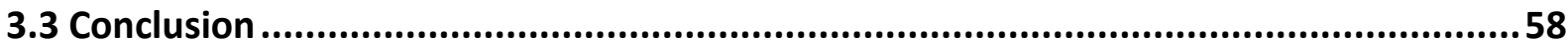

Defining MSD's policymaking process in the development of Te Pae Tata ...................................................5

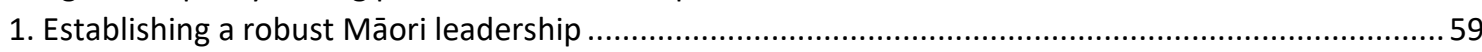

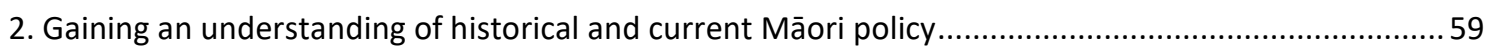

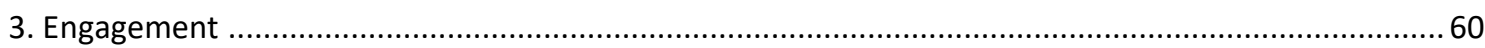

4. The utilisation of mātauranga Māori and Tikanga throughout the development process. ....................60

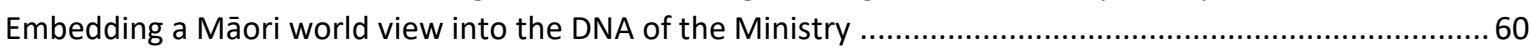

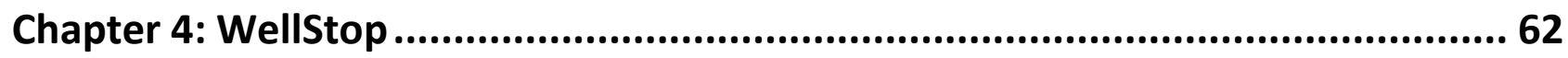

4.1 WellStop's vision, values, whakataukī and karakia ..................................................64

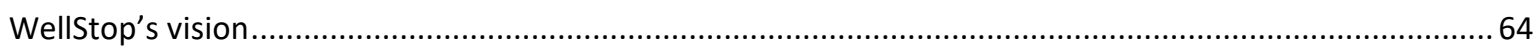

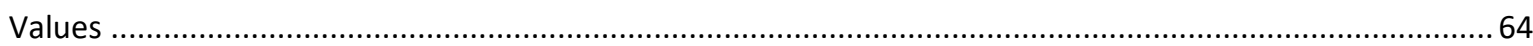

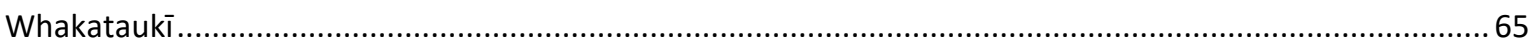

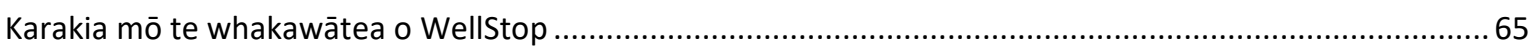

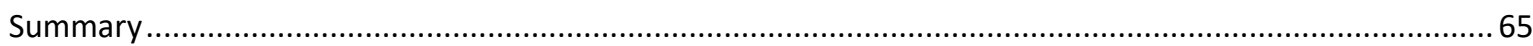

4.2 WellStop's external influencers for creating Māori responsive policies ......................65

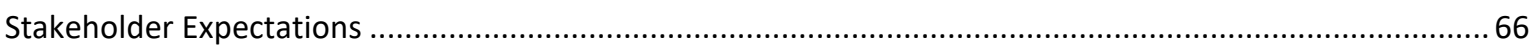

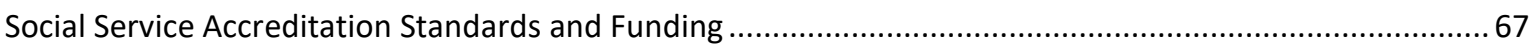

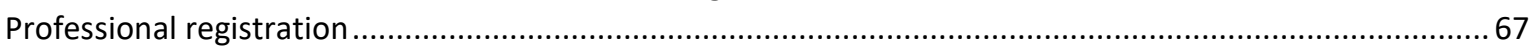

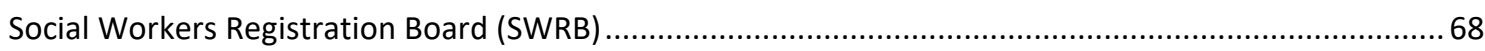

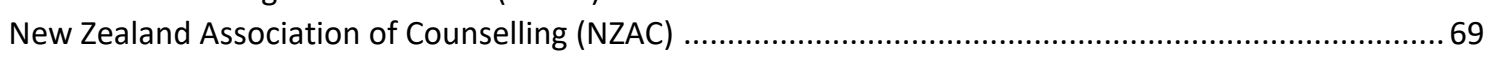

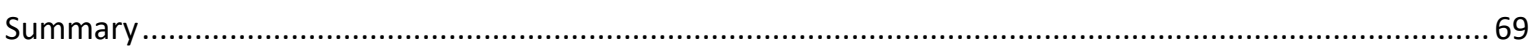

4.3 Interview with Mark King, the Chief Executive Officer of WellStop: ............................70

4.4 WellStop's Māori Strategy: Development and implementation 2019 - 2020................75

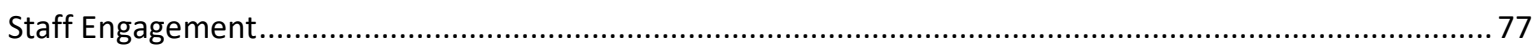

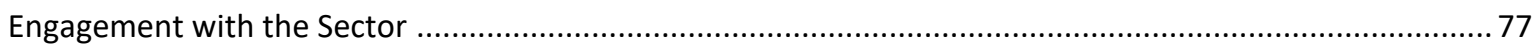

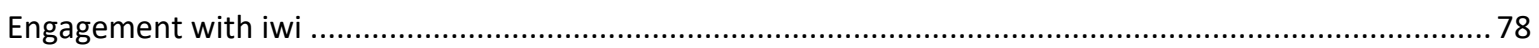




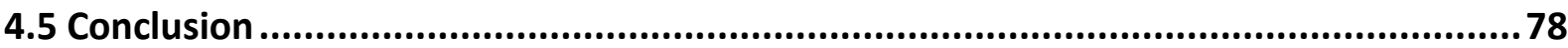

Why has WellStop created a policy/policies that are responsive to Māori? What are the influencers? .........78

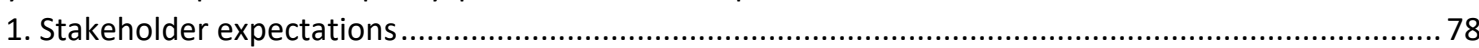

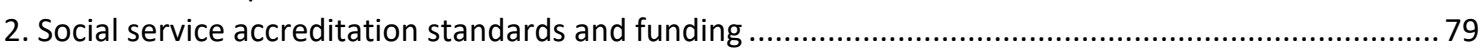

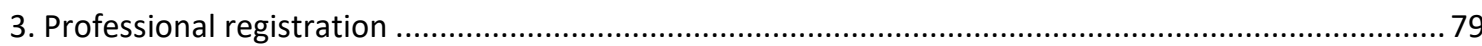

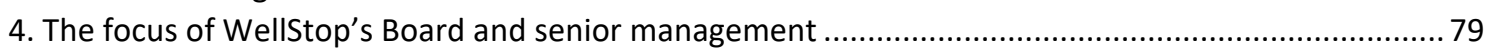

What steps has WellStop taken in the development of their Māori Policy and what tīkanga and mātauranga

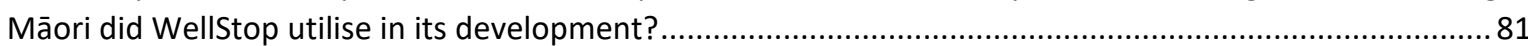

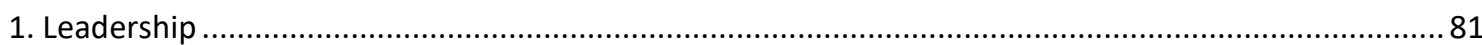

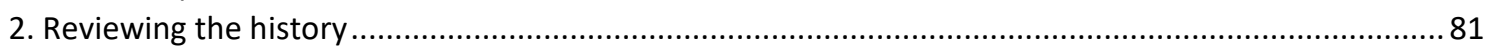

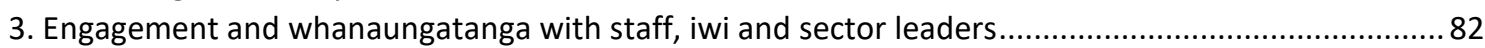

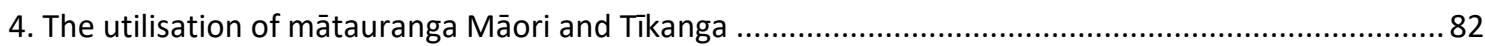

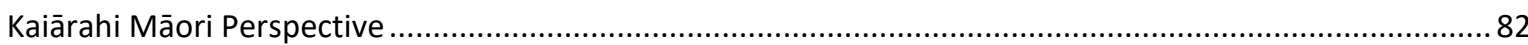

\section{Chapter 5: Conclusion: Osmosis - the accumulative learning for the formation of} Māori policy....................................................................................... 84

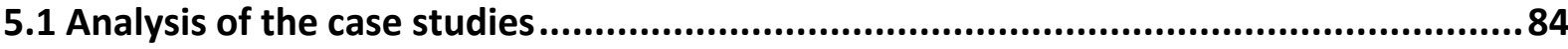

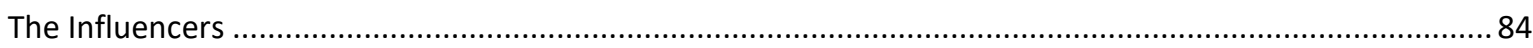

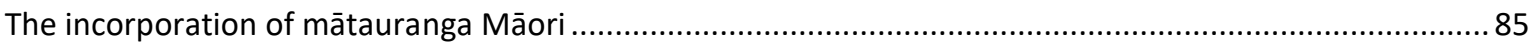

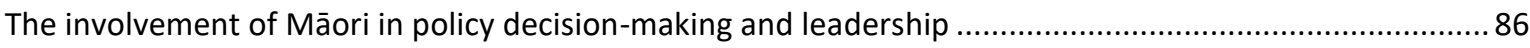

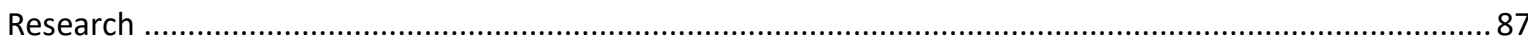

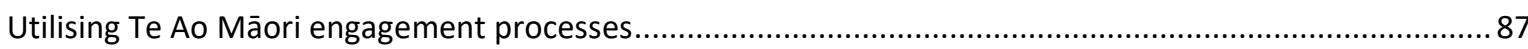

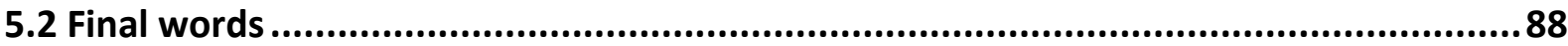

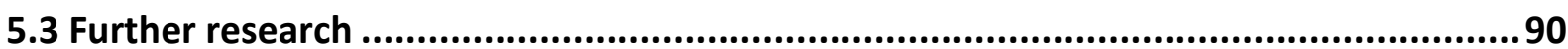

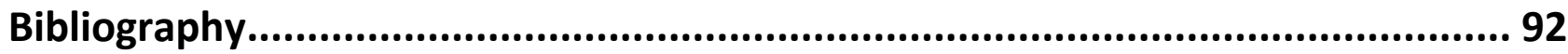

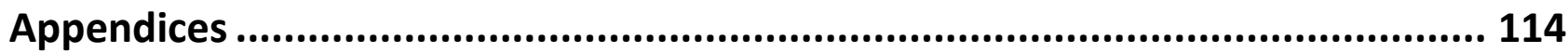

Appendix A: Consent to participate form (organisations) ………........................................................ 114

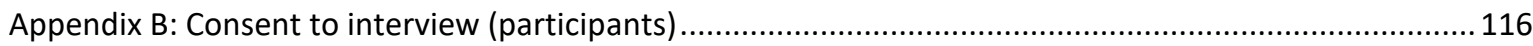

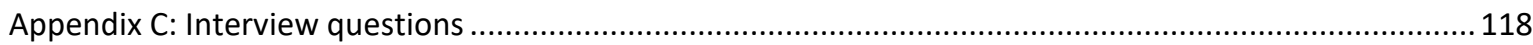

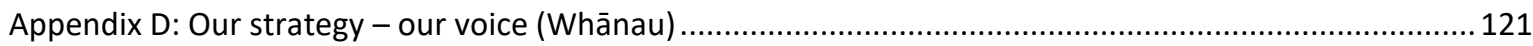

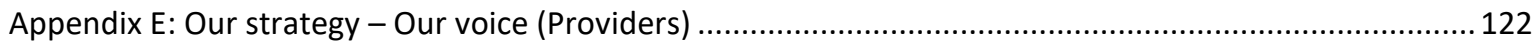

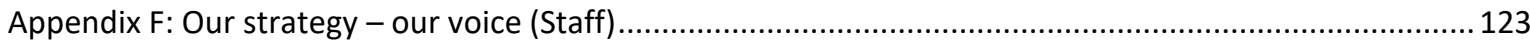

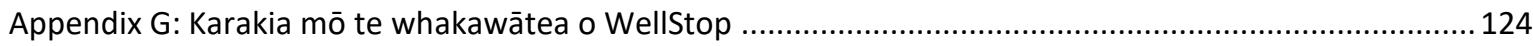

Appendix H: WellStop Kaiārahi Māori Progress Report............................................................................. 126 


\section{Glossary}

A

Āhua

Āhurutanga

H

Hapū

Harakeke

Hinengaro

Hōhā

Hōhonu

Hui

I

Iwi

K

Kaiārahi (noun) shape, appearance, condition, character, likeness, nature, figure, form.

(noun) warmth, comfort.

(noun) kinship group, clan, tribe, subtribe - section of a large kinship group and the primary political unit in traditional Māori society. It consisted of a number of whānau sharing descent from a common ancestor, usually being named after the ancestor, but sometimes from an important event in the group's history. A number of related hapū usually shared adjacent territories forming a looser tribal federation (Iwi).

(noun) New Zealand flax, Phormium tenax - an important native plant with long, stiff, upright leaves and dull red flowers.

(noun) mind, thought, intellect, consciousness, awareness.

(noun) nuisance, bother, bore, hassle, pain in the neck.

(verb) to be deep, esoteric.

(noun) depth.

(noun) gathering, meeting, assembly, seminar, conference.

(noun) extended kinship group, tribe, nation, people, nationality, race - often refers to a large group of people descended from a common ancestor and associated with a distinct territory.

(noun) guide, escort, counsellor, conductor, escort, leader, mentor, pilot, usher. 
Karakia

Kaitiakitanga

Kaupapa

Kaupapa Māori

Kaumātua

Kete Whakairo

Kōrero

Korowai

Kotahitanga

Kuia

M

Māhaki

Manaaki

Manaakitanga

Māoritanga (noun) incantation, ritual chant, chant, intoned incantation, charm, spell

(noun) guardianship, stewardship, trusteeship, trustee.

(noun) topic, policy, matter for discussion, plan, purpose, scheme, proposal, agenda, subject, programme, theme, issue, initiative.

Māori approach, Māori topic, Māori customary practice, Māori institution, Māori agenda, Māori principles, Māori ideology - a philosophical doctrine, incorporating the knowledge, skills, attitudes and values of Māori society.

(noun) adult, elder, elderly man, elderly woman, old man - a person of status within the whānau.

(noun) finely woven patterned baskets - each traditional pattern has a name.

(noun) speech, narrative, story, news, account, discussion, conversation, discourse, statement, information.

(noun) cloak ornamented with black twisted tags or thrums...

(noun) cloak - in modern Māori this is sometimes used as a general term for cloaks made of muka (New Zealand flax fibre).

(noun) unity, togetherness, solidarity, collective action.

(noun) elderly woman, grandmother, female elder.

(verb) to be inoffensive, mild, meek, calm, quiet, placid, humble, tolerant.

(verb) (-tia) to support, take care of, give hospitality to, protect, look out for - show respect, generosity and care for others.

(noun) hospitality, kindness, generosity, support - the process of showing respect, generosity and care for others.

(noun) Māori culture, Māori practices and beliefs, Māoriness, Māori way of life. 
Mātauranga

Mātauranga Māori

Mauri

Mihi whakatau

$\mathbf{N}$

Noa

Pā

Pōwhiri / Pōhiri

$\mathbf{R}$

Rangimārie

Rongoā

Rūnanga (noun) knowledge, wisdom, understanding, skill - sometimes used in the plural.

Māori knowledge, wisdom understanding, skill.

(noun) life principle, life force, vital essence, special nature, a material symbol of a life principle, source of emotions - the essential quality and vitality of a being or entity. Also used for a physical object, individual, ecosystem or social group in which this essence is located.

(noun) speech of greeting, official welcome speech - speech acknowledging those present at a gathering.

(verb) to be free from the extensions of tapu, ordinary, unrestricted, void.

(noun) fortified village, fort, stockade, screen, blockade, city (especially a fortified one).

(noun) invitation, rituals of encounter, welcome ceremony on a marae.

(noun) peace, peacefulness, harmony.

(noun) remedy, medicine, drug, cure, medication, treatment, solution (to a problem), tonic.

(noun) council, tribal council, assembly, board, boardroom, iwi authority - assemblies called to discuss issues of concern to Iwi or the community.

\section{$\mathbf{T}$}

Taha (noun) side, margin, edge, bank (of a river), beside. 
Takahi

Tamariki

Taniko

Tapū

Taukumekume

Taura

Te Reo Māori / Te Reo

Tikanga:

Tinana

Tino Rangatiratanga

Toka tū moana

Tūpato / Kia tūpato (noun) part, portion, section.

(verb) (-a) to trample, tramp, stamp, tread, abuse, disregard.

(noun) children - normally used only in the plural.

(noun) border for cloaks, etc. made by finger weaving.

(stative) be sacred, prohibited, restricted, set apart, forbidden, under atua protection

(noun) restriction, prohibition - a supernatural condition. A person, place or thing is dedicated to an atua and is thus removed from the sphere of the profane and put into the sphere of the sacred. It is untouchable, no longer to be put to common use.

(noun) struggling, arguing, conflict, dispute, disagreement, discord, dissention.

noun) rope, cable, cord, hawser.

Māori language

(noun) correct procedures, customs, habits, lore, methods, manners, rules, ways, codes, meanings, plans, practices, conventions, protocols - the customary system of values and practices that have developed over time and are deeply embedded in the social context.

(noun) body, trunk (of a tree), the main part of anything.

(noun) self, person, reality - as opposed to an apparition.

(noun) self-determination, sovereignty, autonomy, selfgovernment, domination, rule, control, power.

(noun) rock standing in the ocean - sometimes written as toka-tūmoana or tokatūmoana.

(verb) to be cautious, careful, wary, suspicious, alert, vigilant usually followed by kei before a verb and $k i$ or $i$ before a noun phrase. 
Wairua

Whakaaro

Whakanoa

Whakapapa

Whakarite

Whakataukī

Whakawhanaungatanga

Whānau

Whanaungatanga

Whare

Whāriki

Whiri (a) (noun) spirit, soul - spirit of a person which exists beyond death. It is the non-physical spirit, distinct from the body and the mauri. To some, the wairua resides in the heart or mind of someone while others believe it is part of the whole person and is not located at any particular part of the body.

(noun) thought, opinion, plan, understanding, idea, intention, gift, conscience.

(verb) (-ia,-tia) to remove tapu - to free things that have the extensions of tapū, but it does not affect intrinsic tapū.

(noun) genealogy, genealogical table, lineage, descent reciting whakapapa was, and is, an important skill and reflected the importance of genealogies in Māori society in terms of leadership, land and fishing rights, kinship and status. It is central to all Māori institutions.

(verb) (-a,-hia,-ngia) to arrange, adjust, organise, put in order, appoint, assign. To balance by equivalent, in like manner.

(noun) proverb, significant saying, formulaic saying, cryptic saying, aphorism. Like whakatauākī and pepeha they are essential ingredients in whaikōrero.

(noun) process of establishing relationships, relating well to others.

(noun) extended family, family group, a familiar term of address to a number of people - the primary economic unit of traditional Māori society. In the modern context the term is sometimes used to include friends who may not have any kinship ties to other members.

(noun) relationship, kinship, sense of family connection (noun) house, building, residence, dwelling, shed, hut, habitation. (noun) floor covering, ground cover, floor mat, carpet, mat. (verb) (-a,-hia,-ngia) to twist, plait (a rope, etc.), weave, spin. 


\section{Chapter 1: Introduction}

Firstly, I am Tainui, Tongan, and Fijian, born and raised in Papakura, South Auckland. I have worked as a social worker for over 30 years, beginning in the late 1980s in South Auckland. I became qualified in social work in 1997 at Victoria University, have been employed with both government and non-government organisations (NGOs), and am currently the Kaiārahi Māori - Māori Development Manager for WellStop.

Policy that has been developed to meet the needs of Māori is nothing new. In fact, our nation's history is riddled with policies that affect Māori. Some policies have been developed for Māori where Māori are external to its development process such as those that were developed following the release of the Hunn Report (1961), namely the incentivisation for Māori to move from rural areas to cities (urbanisation) to help them either integrate or assimilate into society. Other policies have been developed utilising engagement with Māori but have retained a non-Māori perspective, falling short of Māori expectations and hopes. A significant example of this is where the Māori Perspective Advisory Committee (the Advisory Committee), chaired by John Rangihau, travelled throughout New Zealand to hui with Māori from many different iwi to learn about and understand their views and experiences about the Department of Social Welfare. The Advisory Committee's purpose was to provide the Minister of Social Welfare with a Māori perspective on '...aspects of the Social Welfare Department which are detrimental to the Maori people.' They honoured the voices of Māori in the damning report Puao-Te-Ata-Tu (Department of Social Welfare, 1988). The report exposed institutional racism, which is defined as '...a pattern of differential access to material resources and power determined by race, advantages one sector of the population while disadvantaging another.' (Came H. A., 2012). The term described the attitudes and treatment of Māori at the hand of the staff of the Department of Social Welfare and made many recommendations to rectify the situation. The recommendations implored the Minister to attack all forms of cultural racism in New Zealand by incorporating Māori values and beliefs in all policies, sharing resources (devolution), and developing initiatives which harness all people but especially Māori to advance. As with many advisory reports throughout New Zealand's history, Puao-Te-AtaTu was only successful in part, in that it was responsible for (among other things) amendments to 
the Child, Youth and their Families Act which required that the Department utilise traditional whānau processes. Although they are state-mandated, Family Group Conferences enabled Māori whānau to be involved in their children's solutions.

Many subsequent reports have repeated similar recommendations to those in Puao-Te-Ata-Tu, engagement, partnership, devolution of powers, adopting a Māori ethos. Yet, we have not seen policies that have made a significant difference to improve outcomes for Māori since they have been, and still are, highly represented in many negative social indicators. This indicates that something significantly different needs to happen to achieve better outcomes for Māori. What we have seen though, is a gathering momentum towards policymaking that is more responsive to Māori, moving away from forcing Māori to integrate or assimilate with European society, to putting Māori interests and aspirations at the fore. This brings us to the case studies in this thesis that aspire to create significantly different policies from past ones to improve outcomes for Māori.

\subsection{Aims and Objectives}

\section{Aims}

This study aims to understand why organisations are finding it necessary to develop Māori responsive policies and how Māori policy is formulated and implemented in the current historical moment when the government is committed to centring Māori needs and aspirations throughout the public sector. The associated aims are to identify commonalities and best practices in the development of Māori policy and to understand what Māori policymaking involves.

\section{Objectives}

This study's main objectives are to understand the influencers behind the development of Māori policies and document the formulation and implementation of Māori Policy in two case studies: one of a governmental and one of a non-governmental organisation. I will examine the Ministry of Social Development's (MSD's) statement of intent (2018 to 2022) which includes the new strategic direction Te Pae Tawhiti, and the development of MSD's Māori strategy and action plan, Te Pae Tata 
(Ministry of Social Development, 2019 (g)). I will also examine the development of WellStop's Māori policy/framework Te Kupenga. The examination of the development of these policies will help to build an understanding of the importance of the inclusion of Māori in all aspects of Māori policy development and the integration of mātauranga Māori within Māori policy and Māori policymaking processes.

\subsection{Research methodologies}

\section{Kaupapa Māori research}

Kaupapa Māori theory and research methodologies are well-established within academia through the discussions of many theorists (Cram, 2009; Cram, 2001; Moewaka Barnes, 2000; Taki, 1996; Smith G. H., 1997; Pipi, et al., 2002; Te Awekotuku, 1991; Smith L. T., 2006 (b); Smith L. T., 1999). Kaupapa Māori research utilises Māori cultural values, practises (Pipi, et al., 2002) and principles to build meaningful relationships (Pohatu, 2013) with participants '... from a Māori platform so you are not looking from the outside at Māori, you are in it with Māori...' (Te Rau Matatini, 2017). Kaupapa Māori research establishes a safe space whose premise is for the benefit of the Māori participants, and the end-user, the wider Māori community, whānau, hapū, and iwi (Bishop, 2005).

As such, I felt that it was necessary to utilise values that are central to Māori, passed down to me from my kaumātua and kuia, during the kanohi ki te kanohi, face-to-face interviews. The values used reflect the research ethical values and principles expressed by Cram (2001), Cram (2009), Smith, L. T. (1999), Smith L. T. (2006 (b)), (Ngata, 2017) and Pohatu's (2013) principles of building meaningful relationships. These values are;

- Whanaungatanga - creating an opening for close connections through shared narratives.

- Manaakitanga - ensuring that mana is enhanced before, during and following the interviews, including meeting on their Turangawaewae, a place where one has the right to stand.

- Mahaki: Entering the relationship from a naïve enquirer place of humility.

- Kia tūpato: To engage with caution, conscious of the needs of the participants. 
- Âta-whakarongo: Listening with openness and understanding, allowing the participant to genuinely express their story in their own time and on their own terms.

- Tika me te pono: To operate with integrity entering the interview space from a Te Ao Māori understanding of correctness and truth, ensuring that the participants' narratives are presented correctly and truthfully.

\section{Research Positioning}

When discussing a researcher's positioning or status as an 'Insider' or 'Outsider', consideration must be made regarding what each represents. An outsider, as a non-member of the research group or community, can provide a more objective point of view through scientific detachment (Kikumura, 1998). In contrast, an insider has the ability to understand and interact with a group or community from a perspective that is unavailable to an outsider $(\mathrm{Xu}, 2016)$. Banks' (1998, p. 8) describes researchers' status in four categories; the indigenous-insider; the indigenous-outsider; the externalinsider; and the external-outsider. Each has a varying degree of connection with the research group or community. Rabe (2003) describes the qualitative researchers' status as fluid, flowing in and out of being an insider and an outsider. I am both an insider and an outsider to this research in many ways. I am an insider in so far as being a Māori completing a study of and for Māori, as an employee, previously with MSD and currently with WellStop, and lastly as a senior manager and cultural advisor of an organisation. However, as I don't share the exact experiences and traits of the participants in my research, or all Māori, or all MSD and WellStop employees, or all senior managers and cultural advisors, I could also be considered, in part, to be an outsider to this research. To be both an insider and outsider, dwelling in the 'The space between' (Dwyer \& Buckle, 2009), is contradictory in that as an insider-in-part, you cannot have the complete objectivity of an outsider, and again, as an outsider-in-part you cannot have complete, in-depth relatability with the participants and their experiences. Having said this, it is accurate to say that the better part of this research was conducted from an insider's positioning, which through my cultural, organisational, and managerial knowledge and experience, has afforded me with the ability to draw closer to my research participants (Taylor, 2011) with the benefits of accessibility, pre-understanding, and the ability to navigate organisational politics (Brannick \& Coghlan, 2007). Taylor (2011) discusses some of the difficulties of being an Insider. In particular, she points out that distinguishing her role as a friend to the research subjects from her role as the researcher can be problematic. As is the case with my role as the Kaiārahi Māori 
for WellStop. Therefore, for clarity in Chapter 4, I speak of my activities as the Kaiārahi Māori in the third person.

\subsection{Case studies}

Case study research allows for 'an in-depth exploration from multiple perspectives of the complexity and uniqueness of a particular project, policy, institution, program or system in a 'real life' context' (Simons, 2009, p. 21). It is not a method itself but rather is a framework that may incorporate several methods (Thomas \& Myers, 2015). I conducted a qualitative case-study analysis of two organisations engaged in Māori policy development: MSD, a government organisation, and WellStop, a contracted NGO service provider. These two cases of Mãori policymaking are distinct in that one is governmental and the other a non-governmental organisation. MSD is one of the largest government organisations whose approach to Māori engagement and responsiveness comes from a government perspective. WellStop is an industry leader in combatting harmful sexual behaviour (HSB), whose approach to Māori engagement and responsiveness comes from an NGO perspective. Also, MSD and WellStop have a symbiotic relationship in that MSD provides funding for NGO service providers, and WellStop is one such provider. This means that MSD has a voice in how WellStop operates, a voice that is influenced by the government's aspirations of the day. This thesis will show how MSD's focus on Māori responsiveness and engagement directly affects how WellStop approaches their Māori responsiveness policies.

Qualitative analysis is the study and interpretation of unquantifiable information (qualitative research), including case studies, interviews, and interactional and visual texts (Denzin \& Lincoln, 2005). My case studies involved qualitative, in-depth, semi-structured interviews with two key informants and qualitative analyses of policy documents from the two organisations. For this thesis, the qualitative research and analysis helped gain an insight into the participant's point of view and the detailed and implicit meanings of policy documents. (Bhandari, 2020).

\section{Interviews}

The ethics approval allowed for interviews with; Hohepa Patea, the Principal Māori Advisor for MSD; 
Mark King, the CEO for WellStop; and Hera Clark, the Principal Māori Advisor for Oranga Tamariki. However, by the time the interviews were to occur, Hera Clark was no longer available. Also, due to a change in Oranga Tamariki's research application process, permission to complete an interview with someone else could not be approved within an appropriate timeframe. Therefore, Oranga Tamariki has been excluded from my final thesis.

Hohepa and Mark's involvement was essential in providing insight into how and why these policies and strategies were formed and how their voices significantly influenced their policies' forethought and essence (mauri). This is one point of deviation from non-Māori policy. Their passion and dedication to a Māori lens is the catalyst and authority for the development of the Māori policies for their organisations. Arguably, without them, I doubt the policies would be adopted and embedded as they demand a truth that is based on their Māori experiences and knowledge.

While there were set questions for this research, it was important for this study to allow the participants the freedom to share their own narrative about their experiences, to not dictate the way the information should be shared. The onus and respect were given to them to lead the conversation as they felt fit. This traditional process of information transfer is similar to one that would be utilised to learn genealogy from a whakapapa expert. From this manaakitanga and mahaki stance, my thoughts and agenda are not the essence of what is most essential but instead being available to àta whakarongo, listen with openness, and be guided by the kaitiaki of the information. My responsibility is also to be tika me te pono, to pass on their narrative in the manner and mauri in which it was given. This level of reverence and respect placed these interviews in an āhurutanga of tapū. The result of enlisting a traditional and cultural process was an open dialogue that would not have been achieved by structuring the time with rigid questioning. This does not undermine the value of the set interview questions but instead adds value. It allowed their narrative to enhance the information sharing process with only a small amount of prompting from myself to ensure that the questions and the study's aims were covered. This process also opened the door for a peerbased conversation to flow. The respect for each other's skill and experience enhanced the freedom to kōrero with or without Māori, to provide answers from a metaphorical or whakataukī base without hōhā, without the frustration or annoyance of needing to explain every word. 


\subsection{Research Ethics}

The Victoria University of Wellington (VUW) Human Ethics Committee approved this study on 18 April 2019 (Ref: 27380) based on the premise that the research examined the process of tīkanga and its translation into policy and, in turn, the use of te reo Māori (te reo) and an exploration into 'How' these policies were formed including; hui tīkanga or protocols used in meetings; the participants, organisations, hapū and iwi involvement; tīkanga and its application to policy; mauri/wairua or holistic processes used; and what consultation took place to ensure the efficacy of the terms and meanings included in the policies.

As such, the following documents were also approved by the VUW Human Ethics Committee and were sent to participating organisations and interviewees:

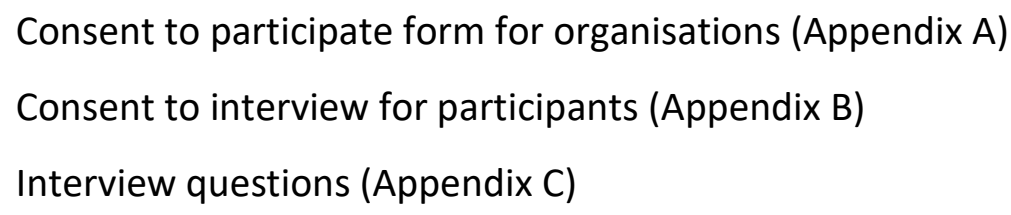

Initial contact with Hohepa was over the phone, where I provided him with a brief explanation of who I am, my role, the background and aims for my study and the relevance of MSDs policies for my research. He gave verbal permission for a one-on-one interview with him. We also discussed engagement protocols for our interview. We agreed to utilise a process of pōwhiri/mihi whakatau to enable the mauri of tapū and noa to reside within and after the interviews. Initial contact with Mark regarding this study was face to face, where we discussed the background, aims, and the relevance of WellStop's Māori policy for this study. He also gave verbal permission for a one-on-one interview, and we discussed protocols, pōwhiri/mihi whakatau and how the interview would be conducted.

Before the interviews, I provided Mark and Hohepa with a further written explanation of who I am, my role, experiences and background, a brief explanation on the purpose of this study, ethics consent forms (Appendices $A$ and $B$ ) and a copy of the questions posed (Appendix C). This enabled each participant to go over the questions before the interview. Both Mark and Hohepa provided signed consent forms before the interviews were conducted. 
I understood that Mark and Hohepa's time is precious. Therefore, I allowed them to set the time and place for the interview, making myself available at the most suitable place and time for them. It was vital to whanaungatanga or build kinship and rapport quickly. This included the use of te reo, tīkanga and sharing of whakapapa and pepeha.

With Hohepa, it was unnecessary to ask the set questions during the interview as his narrative answered all the questions posed. Mark provided written answers to the questions, and his interview was provided from a narrative perspective free from any restrictions inherent in having to answer set questions. As a result, I was able to capture the how and why of their policymaking and the depth of personal desire and the investment of heart they both have made to give birth to their policies.

\section{Ethical reflection on the interview process}

The insider qualitative research methodology posed some ethical questions, including the duality of role as a researcher of Māori policy within WellStop while being a cultural advisor for WellStop. Often, my dual role of being the researcher on the job and as a cultural advisor were intertwined (Taylor, 2011). This could be seen as a crossing of ethical boundaries, for example, the ability to influence the outcomes. However, my role as a cultural advisor within WellStop is to ensure the efficacy of the Māori policies, to apply a Māori lens to those policies while encompassing the aspirations of WellStop. Therefore, it was important for this thesis to note that the aspirations and final decisions for WellStop's Māori policy (through direct quotes found in chapter 4) lie with the CEO of WellStop. I, as the Kaiārahi Māori, only assisted. There is also the question of the power dynamic between a subordinate and superior within the research, including whether a subordinate should be interviewing their employer and whether the interview process would be altered by the employer-employee relationship. As expressed earlier, as an insider, it was beneficial to have foreknowledge of both Mark and WellStop as an organisation. It allowed for accessibility and navigation of organisational politics. My relationships with Mark and Hohepa are respectful. Therefore, it was important for this thesis to ensure that Mark and Hohepa's voices, views, and mauri were expressed with tika me te pono, truthfulness and integrity. 
A Kaupapa Māori methodology was utilised to address Māori tīkanga of kanohi ki te kanohi, which is a key Māori communication principle that, '...allows one to not only see who or what one is communicating with, but also to hear, feel, and smell the relationship.' (Ngata, 2017). With this vital tīkanga in mind, our face-to-face contact for Hohepa and Mark needed to be executed correctly. Their collective status or roles are essential, but the tīkanga takes precedence to ensure face-toface communication is covered by tīkanga. To add, allowing their schedules to dictate times and dates was not about a subordinate or superior relationship but assuredly was in the spirit of kia tupato, respecting the needs of the participants. It was also to adhere to the tīkanga of respecting their turangawaewae, respect afforded to those whose spaces we enter to kanohi ki te kanohi. To explain, Mark's office may have been a place I entered daily, however for this purpose, we endorsed and applied the turangawaewae status to highlight and create time to pay respect to the policies being spoken of. This impresses the importance of ensuring that the time was suitable to make the way clear and to have the essential time to engage and address the significance of their respective Māori frameworks/lens' have for each organisation.

\section{Case Study Policy Documents}

\section{MSD}

Hohepa provided several factsheets (Appendices D, E and F) that he used to explain Te Pae Tawhiti and the development of Te Pae Tata. These documents are readily available on MSD's website along with other Ministry publications that have been used for the research in this study, such as MSD's history, MSD's Statement of Intent and the finalised Te Pae Tata document, which are unavailable elsewhere. I also drew on some quantitative data from MSD documents, such as benefit statistics.

\section{WellStop}

Mark permitted the use of the WellStop Kaiārahi Māori Progress Report (Appendix H) and the two factsheets featured in chapter 4. Other information regarding WellStop was sourced from the WellStop website, which is unavailable elsewhere.

\subsection{Literature}


I would like to acknowledge the many notable authors who have contributed to this study through the provision of discourses on New Zealand's history of colonisation (Anaru, 2011; Durie M., 2003; Moewaka Barnes \& McCreanor, 2019; Reid, Rout, Tau, \& Smith, 2017; Wihongi, 2010); Te Tiriti o Waitangi (Ross, 1972), its principles (Hayward, 2012 (b)), and their application to policymaking (Came, O'Sullivan, \& McCreanor, 2020) and social policy (Barrett \& Connolly-Stone, 1998). Also, the detrimental effects of urbanisation and neoliberal policies (Cavino, 2016; Consedine, 2007; Dociu \& Dunarintu, 2012; Hackell, 2007; Hayward, Biculturalism, 2012; Larner, 2002; McLean, Long, Stretesky, Lynch, \& Hall , 2019; Meredith, 2005; Morrow, 2014; Nsiah-Gyabaah, 2003; Ongley, 2013; Tolerton, 2010; Williams D. V., 2019; Willis, 1994; Zahariadis, 2005); and the disparities that exist between Māori and non-Māori (Henare T. , 1998; Humpage \& Fleras, 2001; Janssen \& Forbes, 2014; Levy, 1999; Marriott \& Sim, 2014; Parata, 1994; Sutherland, 2020), the history of New Zealand's radical protests (Hill R. , 2009, pp. 149-153; Keane, 2012(a), 2012(b); Walker, 1984), historical privilege from historical trauma (Borell, Barnes, \& McCreanor, 2017; Came H. A., 2012; Farrelly, Rudegeaire, \& Rickard, 2006), and the evolution of Māori policy (Belgrave, 2014; Hetaraka, 2019; Hill R. , 2009, 2010; Kiro, 2001; Maaka R. C., 2003; McCreanor, 1993; Maaka \& Fleras, 2009; Mitchell, 2009; Moon, 2009; Newbold, 2007; Rakena, 1961; Thomas \& Nikora, 1992).

I'd also like to acknowledge those authors that have provided discourses that contribute to building an understanding of mātauranga Māori (Awatere \& Harmsworth, 2014; Best, 1924; Brougham \& Reed, 2012; Broughton \& McBreen, 2015; Calman, 2012; Cowan, 1955; Derby, 2013; Hikuroa, 2017; Houkamau \& Sibley, 2019; Justice, 2018; Kendell, 2007; Mark, Chamberlain, \& Boulton, 2015; Mead, 2016; Metge \& Jones, 1995; Rameka, 2016; Rewi, 2010; Royal T. A., 2005, 2007; Ruru, Roche, \& Waitoki, 2017), moving beyond tokenism (Boulton, Levy, \& Cvitanovic, 2020; Lundy, 2018; Morris \& Alexander, 2017; Pohatu, 2013; Tolich, 2002; Williams R. T., 2013), Māori processes of engagement (Bishop, 2005; Cram, 2001, 2009; Hook, Waaka, \& Raumati, 2007; Innes \& Booher, 2003; Lowry \& Simon-Kumar, 2017; Maaka R. C., 2003; Mahuika, 2015; Moewaka Barnes H., 2000; Ngata, 2017; Pihama, Smith, Taki, \& Lee, 2004; Pipi, et al., 2002; Pohatu, 2013; Smith G. H., 1997, 2017; Smith L. T., 1999, 2006 (a), 2006 (b); Swain, 1987; Taki, 1996; Te Awekotuku, 1991), and indigenous participation in policymaking processes (Bargh, 2016; Came, McCreanor, Haenga-Collins, \& Cornes, 2019; Clarke, 2015; Mead, et al., 2003; Sibley \& Houkamau, 2013; Xanthaki \& O'Sullivan, 2009). 
Lastly, l'd like to acknowledge those authors who have contributed to understanding factors for policymaking within NGOs (Beddoe \& Duke, 2009; Bawden, 2008; Ciucescu, 2009; Dale, Mooney, \& O'Donohue, 2017; Freeman \& Mcvea, 2001; Hunt, 2017; O'Brien, Sanders, \& Tennant, 2009; Siliunas, Small, \& Wallerstein, 2019; Te Momo, 2015); and policymaking processes (Weible, 2018; Weible \& Sabatier, 2018; Janssen \& Forbes, 2014). I acknowledge their contributions to the ongoing definition of Māori policy and the making thereof. However, to my knowledge, there is little or no literature that encompasses one of the aims of this thesis, which is to document the formulation and implementation of Māori policy, as it is being made, identifying commonalities and best practices might be helpful for future policymakers.

\subsection{Research limitations}

What is Māori policy? While I make some conclusions with regards to Māori policy, the scope of my research is limited to just one government organisation and one NGO. Therefore, it can only be considered a snapshot of what defines Māori policy.

This study discusses tokenism and the strong sense of cynicism among Māori, which creates a challenge for organisations seeking to engage with Māori. It identifies some valuable insights into the benefits of utilising mātauranga Māori and tīkanga to generate a sense of authenticity for Māori participants of the engagement process to counter said cynicism. However, again, this is only from the limited scope.

This is related to what defines authentically Māori policy, which is also discussed within this study. Is it determined by the amount of mātauranga Māori content or the understanding of and intent behind its inclusion? These questions are answered within this thesis to a degree. However, it is limited to the scope of one government organisation and one NGO.

This study discusses the cultural competency measures that NGOs must achieve to attain funding and how they influence Mãori policymaking. External to the scope of this thesis however, is examining the development of those measures, whether they have also had significant input from 
Māori. Also, this study does not delve into the policies that iwi and kaupapa Māori social services are developing to cope with the increase of devolution of government services to NGOs.

\subsection{Thesis Outline}

Chapter 2 discusses scholarly and political debates about Māori policymaking and key historical developments in Māori policymaking. It will highlight some of New Zealand's social, economic, statistical, and political developments that have affected Māori and demonstrate the necessity for Māori responsive policies. It will also show that little has changed statistically despite repeated calls for partnership, participation, and protection. It will also look at the government's current mandate with regards to Māori Policy. Against this backdrop, chapters 3 and 4 presents my two case studies. Chapter 3 looks at MSD's Te Pae Tawhiti and Te Pae Tata and includes commentary from Hohepa Patea. Chapter 4 considers WellStop's approach to Māori policymaking, engagement, and Māori participation. It will also include commentary from Mark King. Chapter 5 concludes the main body of this thesis with an osmosis of learning from each case study which shows that while MSD has been influenced to develop policies that are responsive to Māori due to the social, economic, statistical and government aspirational factors, WellStop is influenced by the organisational vision and the parameters set by the expectations of government organisations, (Ministry of Social Development, 2020 (b)) and professional registration bodies (New Zealand Association of Counsellors - Te Roopu Kaiwhiriwhiri o Aotearoa, n.d. (3) \& Social Workers Registration Board, n.d. (1)).

There are similarities in the stages of development in each organisations' policies; the use of whakataukī and karakia, whose inspirational words anchor their policies in Te Ao Māori; the establishment of strong Māori leadership knowledgeable in mātauranga Māori and tīkanga to ensure the policies' cultural efficacy and to drive the mauri of the policies from the top-down; and researching each organisations' previous and current policies that pertain to Māori to understand the historical directions that their organisations have taken to develop more effective policies. Finally, there are valuable findings in their processes of engagement with Māori and the merit in utilising tīkanga processes during engagement with Māori staff, whānau, hapū and Iwi. 
What cannot be denied is the influence of Hohepa and Mark's background knowledge of mātauranga Māori and their heart and drive to see their organisations operate from a Te Ao Māori perspective. What I feel is the most crucial common denominators between Hohepa and Mark's heart and drive is a clear understanding of the importance of keeping people in mind and ensuring that the policies are developed with a strong sense of manakitanga and kaitiakitanga. 


\section{Chapter 2: Historical contributors towards the need for Māori responsive policy}

History has significant value in the policymaking context providing background, historical parallels, reference points and opportunities for new ways of thinking (Haddon, Devanny, Forsdick, \& Thompson, 2015). The Tiriti o Waitangi promised a partnership between Māori and the Crown, protection of Māori land, fisheries, waterways, resources, taonga, cultural way of life and equal rights as citizens of her Majesty's realm. What they got was a raft of legislation and policy that enacted dispossession of land, diminished population, poverty, loss of language, racism (Moewaka Barnes \& McCreanor, 2019) and a loss of customary laws (Durie M. , 2003). In other words, a breakdown of Māori society as they knew it. While colonisation has had quite a detrimental effect on Māori and continues to influence policymaking today, it has been discussed extensively within literature (Moewaka Barnes \& McCreanor, 2019; Anaru, 2011; Reid, Rout, Tau, \& Smith, 2017). Therefore, this chapter will not examine the complete history of Māori social issues and policy. Instead, it will highlight some examples of New Zealand's post World War II social history to help build an understanding of how social issues have significantly influenced legislative and policy decision-making (Weible \& Sabatier, 2018). This contributes to understanding why it is necessary to develop Māori responsive policies. It will also highlight that although there have been many recommendations, legislative changes and policies to address the needs of Māori, not much has changed statistically. Where Māori only represent $15 \%$ of New Zealand's overall population, they are still overly represented in many negative social indicators (for example; Ministry of Social Development, 2018 (b), p. 8; Department of Corrections, 2019; Ministry of Education, 2007, p. 22). There has been much policy to address Māori needs, but not much change in the statistical outcomes, which highlights that something significantly different needs to happen to assist Māori towards self-determination, wellbeing, and success. This chapter aims to identify some indicators of Māori policy best practice by examining history.

Up until the 1980s, government actions have been described as a discouragement of tribalisation (Maaka R. C., 2003; Came H. A., 2012), such as the recommendations for integration/assimilation 
found in the Hunn Report (Hunn, 1961) and the subsequent incentivisation for Māori to urbanise. As Maaka describes it (2003), the reaction to the diminishing of Māori tribalisation gave rise to a self-determination movement, a rising Māori political voice demonstrated in the protest movements, the establishment of Māori political parties and Kaupapa Māori education. Some have let their self-determination voice be heard through the protest movements, which raised public awareness, demanded recognition of breaches of Māori rights under the Tiriti o Waitangi and forced the hand of the government to develop policies that honour the rights afforded to Māori in the Tiriti o Waitangi (Belgrave, 2014). Such a voice has successfully forced the government to consider their responsibility towards Māori and take action, such as establishing the Waitangi Tribunal to address Treaty grievances. Others have taken a more governmental approach by forming Māori-centric political parties to influence change from the inside. And then, some have taken a more proactive stance, not waiting for the government to provide the answers but instigating policies for change such as kaupapa Māori education. These types of Māori voices have revitalised tribalisation and affected a government response to develop policies that are responsive to Māori.

This chapter will cover; the effects that urbanisation and neoliberalism have had on Māori, the rise of a Māori political voice through the protest movements, Māori political parties, and Kaupapa Māori Education. Each is a vehicle to see the revitalisation of tribalisation and a realisation of partnership, participation and protection, as mentioned in the Tiriti o Waitangi. It will also discuss historical government recommendations, legislation and strategies that have tried to create positive outcomes for Māori and the government's current mandate on the development of Māori responsive policy.

\subsection{Urbanisation and Neoliberalism}

Following World War II, New Zealand's economy faired quite well compared to other countries because of our export trade in pastoral products with Britain. During this time of economic stability, the New Zealand government increased public spending, injected funds into various ventures such as the country's transport infrastructure, roads, bridges, and the building of hydro-electric systems, including the Roxburgh dam and power station in 1957 (The Reserve Bank of New Zealand, 2007, 
pp. 7-14). This brought about a greater need for workers. In response, many Māori left their rural, pā way of life to move to urban areas for employment, better housing and education (Consedine, 2007).

For context, before World War II, 80\% of Māori lived in rural areas (Meredith, 2005), but by 1956, that number had decreased to 35\% (Morrow, 2014, pp. 85). By 1960 the government understood that Māori urbanisation was not necessarily temporary. Therefore, as the temporary head of the Department of Māori Affairs, Jack Hunn was tasked with undertaking a comprehensive analysis of all matters pertaining to Māori, which included statistical analyses of several social factors such as health, employment, population, education. Upon completing this analysis, the Department of Māori Affairs released the 'Hunn Report' in 1961. It revealed alarming results for Māori in many social and economic factors, including disproportionate numbers of Māori appearing in court records and academic underachievement, to name but a few. Despite the report's recognition of the detrimental effects of urbanisation for Māori, its recommendations were to encourage even more Māori to move to urban areas to help Māori to assimilate or integrate into non-Māori society (MInistry for Culture and Heritage, 2017 (b)), (Hill R. , 2009, pp. 89-93). Unfortunately, with limited education, the employment opportunities available to Māori were in low-skilled professions, for example, meatworks and factory processing plants (Consedine, 2007). With the decline of the wool industry (1966), the devaluation of the New Zealand dollar (1967), the loss of pastoral trade with Britain (1970s) and two oil shocks (1973 and 1978-1979), New Zealand's economic stability had transformed into a recession (Ministry for Culture and Heritage, 2018 (a)). The government's solution to the economic effects was to impose a wage and price freeze to suppress inflation.

From 1984 New Zealand adopted a neoliberal economic ideology which brought about unprecedented economic restructuring and reform (Ongley, 2013). Larner (2002) discusses how neoliberal ideology meant governments became more willing to devolve social services to Māori. However, it is a double-edged sword since neoliberal economic policies created the conditions for job loss among Māori. Once voted into government in 1984, Labour deregulated the financial market and removed the tariff protection that had previously protected manufacturers from imported product competition. Many manufacturers and large assembly factories such as General Motors, The Ford Motor Company and the New Zealand Motor Corporation could not compete with imports and were forced to close (New Zealand History, 2018). 
Furthermore, new hygiene regulations imposed by our European and United States consumers in the 1980s meant that meat works plants required significant upgrading. Many were unable to complete the upgrades necessary and closed while others closed because there were too many meat works plants and not enough market demand. The meat works closures left whole communities devastated by sudden unemployment and loss of income. One such example is the closure of the Patea Freezing Company in 1982 after almost 100 years of operation. At the time of its closure, the Patea Freezing company provided 700 of the 1000 jobs available in the community (Tolerton, 2010). Willis (1994) writes that manufacturing business closures, including the meatworks, equate to $75 \%$ of New Zealand's job losses from 1980 to 1990 . Mitchell $(2009$, pp. 16) mentions that while unemployment remained relatively low through the 1960 s and 1970s, once it did begin to rise, Māori unemployment rose faster than that of non-Māori. By 1991, unemployment for Māori had reached an all-time high making up just over $25 \%$ of all unemployed (Statistics New Zealand, 2008).

Another side-effect of urbanisation was the vulnerability of children and young people. Migrating to urban areas meant a loss of community restraints, namely, the oversight of their kinship relationships (Swain, 1987). It was not just Māori men who were working, but often, Māori women took up full-time factory work. Without the oversight of their parents or their extended kin, such as kaumatua and kuia within rural settings, children did not have enough supervision (Larner, 2002) and were left to their own devices. Thousands of Māori children and young people during the 1960s and 1970s were arrested, charged and processed by New Zealand's children's courts (Sutherland, 2020), a significant contributor towards the over-representation of Māori within the justice system. Many of these children and young people suffered abuse, mentally, physically, and sexually while in state care (Sutherland, 2020). In 2020, Martin, Jenkins \& Associates Ltd estimated that up to 256,000 children, young people and vulnerable adults suffered abuse while in state care between 1950 and 2019 (Martin, Jenkins \& Associates Ltd, 2020).

Losing the oversight of rural kinship relationships had another detrimental effect for Māori in that there was no regulation for how parents treated their children. The most prevalent examples of this can be found in the highly publicised child homicides of; Baby C (age 2), who died of injuries inflicted by her caregiver in 1987; Delcelia Witika (age 1), who was sexually abused and beaten to death by 
her father in 1991; Craig Manukau (age 11) beaten to death by his father in 1992; James Whakaruru (age 4) who was beaten to death by his mother's partner in 1999; and the physical abuse and eventual death of Hinewaoriki Karaitiana-Matiaha (Lillybing, age 1) by her caregiver in 2000. Cavino (2016) links these kinds of abuse and violence with urbanisation.

\section{Summary}

Colonisation, urbanisation and neoliberalism have had a detrimental effect on Māori. So much so that Maori are still overrepresented in many social indicators to this day, placing significant pressure on the government welfare system and social services nationwide. The government has tried to address the needs of Māori, instigating the commission of many reports, legislation and policy change, which I will discuss later. It also added fuel to the radical Māori protest movement from the 1960s and onwards.

\subsection{The Rising Political Voice of Māori}

\section{Māori Radical Protests}

The Tiriti o Waitangi promised a partnership between Māori and the Crown. However, Māori experiences have been dispossession of land, diminished population, poverty, loss of language, racism (Moewaka Barnes \& McCreanor, 2019) and a loss of customary laws (Durie M. , The health of indigenous peoples, 2003). Māori protest movements have existed in various forms since the colonisation of New Zealand to preserve Māori land, seek justice for the broken promises of colonialists and the Crown, and regain what was lost. Māori activism reached new heights from the late 1960s fuelled by the need for self-determination, to seek compensation for injustices suffered through the Crown's failure to meet the historical promises set out in Te Tiriti o Waitangi. Māori protest groups were formed, such as Nga Tamatoa, who organised the first protests at Waitangi in 1971 (Keane, 2012 (b)). However, many protests dominated much of the media for the next decade and beyond, for example, the Māori Land March led by Dame Whina Cooper (Ministry for Culture and Heritage, 2018 (b)), the 507-day occupation of Takaparawhā (Bastion point) in 1977 (Ministry for Culture and Heritage, 2017 (a)), the occupation of Whāingaroa (Raglan golf course) in 1978 
(Taonui, 2012), and the Hikoi ki Waitangi 1984 (Keane, 2012 (a)). Highly publicised protests demanded Māori rights to tino rangatiratanga (self-determination), triggering political and policy change such as the Treaty of Waitangi Act 1975. It is important to note that this legislation established the Waitangi Tribunal to address current (not historical) Māori claims of breaches of the Treaty of Waitangi but was amended in 1984 to include historical claims dating back to 1840.

\section{Māori Political Parties}

Māori representation in parliament has existed since the passing of the Māori Representation Act 1867. From 1867 till the introduction of the Mixed Member Parliament in 1996, Māori held only four seats in parliament. A small voice but a voice none the less. Associated with the protests of the time was the resignation of Matiu Rata from the Labour Party (Walker, 1984), who was instrumental in establishing the Waitangi Tribunal and was the Minister for Māori Affairs. Hill (2009, p. 179) states that;

'Rata gradually came to consider that his own 'party had become "insensitive" to and "neglectful" of the interests of the Maori people'.'

After resigning from the Labour Party, he founded the Mana Motuhake Party in the hopes of creating a movement less conservative than that of Labour but less aggressive than the direct action of protests.

'The new party's aim of uniting diverse groups of Māori across the country in pursuit of a common political goal was based on a vision of cultural unity. As a Maori academic had put it in 1975, Maori people, rural and urban, tribal and detribalised, all shared 'a common cultural identity and a strong desire to retain this identity on their own initiative'.'

(Hill R. , 2009, p. 181)

Another example of bold political statements for Māori is the crossing of the floor of Hon. Dame Tariana Turia in defiance of her party's (then Labour) stance. She did so to vote in opposition to the Foreshore and Seabed Bill. This led to the formation of the Māori Party, of which she was co-leader with Hon. Pita Sharples (Medallist, 2018). The Māori Party were instrumental in the repeal of the Foreshore and Seabed Act 2004. 


\section{Kaupapa Māori Education}

Te reo almost disappeared. By 1975 less than 5\% of Māori children spoke te reo (Calman, 2012). Te Kohanga Reo National Trust was established with the support of the Department of Māori Affairs, by Māori and for Māori Policies were created from the ideation of educating whānau in traditional Māori child-rearing and transference of knowledge practices, and restoration of te reo. Te Kohanga Reo was first conceptualised by Dame Iritana Tawhiwhirangi, who stated in an interview with Duff (2012) that;

'About 120 Maori leaders came to Wellington between 1980-81. We realised we had to stop expecting the government to revive the language and make it safe, Maoridom had to do it themselves. We've got to get these children at birth, and their families. We had four pilots in Wellington and one in Auckland. Within three years there were over 300.'

Kohanga Reo were so successful that it instigated the development of full immersion Kura Kaupapa (primary schools), the first of which was opened in 1985 and Whare Kura (secondary schools), which were based on a similar Te Ao Māori philosophy. Policy frameworks developed by Māori and for Māori, Kaupapa Māori schools help young people develop a stronger sense of personal and cultural identity (Campbell and Stewart, 2009). The successes of Kaupapa Māori schools are in part responsible for the integration of Māori concepts within current mainstream education policies such as Tātaiako: Cultural competencies for Teachers of Māori Learners, which integrates Māori concepts of ako, wānanga and manaakitanga when working with Māori children and their families (Hetaraka, 2019).

\section{Summary}

Māori have struggled throughout history to obtain self-determination in many forms. Some have let their self-determination voice be heard through the protest movements, which raised public awareness and demanded recognition of breaches of Māori rights under the Tiriti o Waitangi and forced the hand of government to develop policies that honour the rights afforded to Māori in the Tiriti o Waitangi. Such a voice has successfully forced the government to consider its responsibility towards Māori and take action (which I will elaborate on in section 3). These types of Māori voices have aided the effort to revitalise tribalisation. 


\subsection{Historical government policy: Recommendations, legislation and strategies to address change}

\section{Engagement with Māori}

There have been numerous recommendations and legislation changes to improve the Crown-Māori relationship and engagement with Māori. Some examples include; the Race Against Time Report, which encouraged the development of a better relationship between Māori and non-Māori promoting biculturalism (Hayward, Biculturalism, 2012 (a)); the amendment of the Treaty of Waitangi Act 1984; and more importantly, the inclusion of the Principles of the Treaty in over 40 statutes of legislation and court judgements which have immortalised the principles of the Treaty in common law. And there have been even more that have improved the revitalisation of culture, such as the Māori Language Act 1987, which established te reo as an official language of New Zealand. But along the way, there have also been circumstances that have not lived up to Māori expectations, reinforcing the lack of trust in the government's ability to be accurate, correct and fair towards Māori such as, the Puao-Te-Ata-Tu report, which highlighted institutional racism. The PuaoTe-Ata-Tu report of the Ministerial Advisory Committee on a Māori Perspective was a scathing review highlighting institutional racism within the Department of Social Welfare. Research processes for the report utilised an extensive, inclusive engagement process with Māori throughout New Zealand (Department of Social Welfare, 1988, p. 7). True to the voices of those that they engaged with; the report did not mince words. It recommended that the Department needed to illuminate all forms of racism and operate from the perspective of advancing all New Zealanders but especially Māori. Puao-Te-Ata-Tu influenced changes to the Children and Young Persons Act (1989), which included Māori concepts of the whānau community. This established the Family Group Conference process whereby whānau could have input into the plans for their tamariki and that placements for children should first be sought within the family (Kendell, 2007, p. 50). Assuredly, the process of engagement utilised by the Ministerial Advisory Committee was inclusive of thousands of Māori (Department of Social Welfare, 1988, p. 7). Hui were held on Marae, and therefore the Committee needed to adopt Māori tīkanga and kawa. This engagement process gained honest, unadulterated feedback from Māori who participated within the hui (myself 
included). The report itself was faithful to all the Committee's input from Māori. However, despite all the fantastic recommendations that brought hope to Māori, it is still the subject of disappointment because of its lack of implementation (Hollis-English A. , 2012 (b)).

There have been many disappointments for Māori. Another example of this is when the regulation of Kohanga Reo moved from the Department of Māori Affairs to the Ministry of Education. As discussed previously, Kohanga Reo were established by Māori, from a purely Te Ao Māori perspective and, for the most part, unimpeded by government regulation. However, under the Ministry of Education, Kohanga Reo faced a more stringent regulation. Te Kohanga Reo National Trust states (n.d.), 'Such a system of measurement often came at a heavy cost to the kaupapa.' Many Kohanga Reo did not survive.

These are, but two instances of disappointments for Māori. One which endorsed an inclusive, extensive process of engagement utilising Māori tīkanga but was never fully realised; and another that was designed by and for Māori but was subject to astringent regulation resulting in the loss of Kohanga Reo. Such disappointments breed disillusionment, resentment and scepticism towards the government and their ability to embrace Māori in partnership and meet their needs.

\section{Devolution of Services to Maori}

Decentralisation and devolution were mentioned in Puao-Te-Ata-Tu. However, in reaction to the rising political voice of Mãori through the protests movement, the government held a Hui Taumata (1984). Hui Taumata was a summit of Māori leaders (Moon, 2009). These leaders demonstrated scepticism about the welfare state. They recommended a future where services would be provided to Māori, by Māori tribal authorities whereby influencing future policies that devolve authority and resources to Māori (Belgrave, 2014), and '...increasing the involvement of Māori in the delivery of services and the revitalisation of the Māori language and culture.' (Ringold, 2005). Their recommendations called for Māori self-determination while also addressing the social needs of Māori. Since that time, there have been many reports and recommendations concerning improving the Crown-Māori relationship for example; The Race against Time report, which recommended collaboration with Māori and the devolution of authority and resources; and He Tirohanga Rangapu, a green paper released for public discussion which made recommendations on how Crown should 
partner with iwi including devolving management of service delivery and social intervention programmes to iwi. It also recommended that a new structure was needed, one of a partnership between Crown and Māori (Hill R. , 2009, pp. 234-236). In response to this green paper, Labour released Te Urupare Rangapu in November 1988, which endorsed a more horizontal partnership between the Crown and Māori as opposed to a vertical one and included devolution of powers and resources to iwi (Hill R. , 2009, p. 237). Like Labour's Te Urupare Rangapu, National released the Ka Awatea Report in 1991, which also made recommendations on partnership, mainstreaming service delivery to Māori through the government system, and devolution of service delivery and resources to iwi. Hill (2009, p. 249) states that Ka Awatea:

'...envisaged various interventionist measures to deal with Maori socio-economic disadvantage, and recommended that the government 'retain resources and the means of delivering those resources, in order to be able to directly target areas of concern' within Maoridom.'

In 1989 the Runanga Iwi Bill was introduced to parliament, which proposed to devolve authority and resources to iwi if they met specific criteria. Many public submissions argued that the Runanga Iwi Bill did not give Māori autonomy over how they administered those resources and services. Even the Iwi Transition Agency stated that 'Iwi were 'not perceived as governmental or jurisdictional authorities in their own right - as required by the Treaty' (Hill R. , 2009, p. 241). The Runanga Iwi Act 1990 enabled Māori Councils and Runanga to access government funding and support and, as Kiro (2001) states, 'independently implement their own agenda without reference to other public institutions.' Since the enactment of the Runanga Iwi Act 1990, '...Māori have maintained a continuous momentum for self-determination.' (Kiro, 2001).

The Productivity Commission's More Effective Social Service Report (2015) has also made recommendations for change to ensure the delivery of effective social services to help 'Māori to succeed as Māori'. Those recommendations included collaborating with Māori to co-design social services at a governance level and, where possible, that government should devolve its services to Māori providers. This report found that social services worked for some if not most people, but when examined under a microscope that focussed on those people with multiple, complex needs and little capacity to access services, it concluded that; 
'A new approach is required to make a real difference for the most disadvantaged New Zealanders. This approach will require a major shift in thinking and structures. It is both achievable and realistic, but implementation will take time and persistence.'

(New Zealand Productivity Commission, 2015)

A more recent example of cross-collaboration with Māori and devolution of services to Māori is the establishment of the Whānau Ora Initiative. Chaired by Mason Durie, the Taskforce for WhānauCentred Initiatives released their report to the Minister for the Community and Voluntary Sector Hon. Tariana Turia. The scope of the Taskforce included the construction of an evidence-based framework to strengthen whānau capability, providing an integrated approach to whānau wellbeing, creating collaborative relationships between government agencies and whānau services, creating broader relationships between government and community agencies, and improving costeffectiveness (Durie, Cooper, Grennell, Snively, \& Tuaine, 2010). Many of the recommendations in the report were accomplished in the Whānau Ora Initiative launch in 2010, which provides the framework for Whānau Ora development throughout Aotearoa. Whānau Ora embraced a whānaucentred approach towards supporting whānau wellbeing and development. In terms of devolution, Whānau Ora proposed to build the capability of Māori providers to deliver whānau-centred services and moved the implementation of Whānau Ora (Durie, Cooper, Grennell, Snively, \& Tuaine, 2010, p. 62). Each Māori provider is given funding to invest directly into their communities to allow for flexibility and innovative approaches that better meet the needs of whānau (Durie, Cooper, Grennell, Snively, \& Tuaine, 2010, p. 21).

\section{The unshifting statistical disparities}

The Hunn Report 1961 discussed the overrepresentation of Māori in many social indicators, as has the Progress Towards Closing the Social and Economic Gaps between Māori and non-Māori Report (1998), which reviewed government departments' services to Māori and reported that despite policy, legislative and strategic change the statistical disparities between Māori and non-Māori still existed. It also expressed the need to close the gap between them (Henare T. , 1998). Labour responded to Te Puni Kōkiri's report with the Closing the Gaps and Capacity Building Policies (Turia, 2000). Currently, Māori represent only 15\% of New Zealand's overall population, and are still overly represented in many negative social indicators (Ministry of Social Development, 2018 (b), p. 8), 
(Department of Corrections, 2019), (Ministry of Education, 2007, p. 22). The fact that there has been so much policy to address Māori needs and not much has changed in the statistical outcomes highlights that something needs to be different to assist Māori towards self-determination, wellbeing, and success.

\section{Summary}

It is important to identify the different types of policy discussed so far and their associated processes. The Hunn Report 1961 sought to aid Māori by encouraging assimilation/integration with non-Māori society through urbanisation. It proposed an imposed solution for Māori issues; however, the incentivisation policies that followed only created more deprivation and poverty, cascading into violence and crime, to name a few.

The 'By-Māori for-Māori' ethos of Kaupapa Māori education had its beginnings steeped in tīkanga Māori and a Te Ao Māori worldview. It succeeded in increasing the academic achievement of Māori children, however after a time became strictly regulated, and many closed because of it. From this, we can gage that where Māori have autonomy over how they enact tribalism/indigeneity, it can be successful and maybe we need more of this. Devolution of authority and resources aims to do this; however, to access that authority for self-determination, Māori need to meet the right criteria. Therefore, devolution of authority and resources provides self-determination, yet the true decisionmaking, whether Māori meet that criteria or not, still sits with the government. In saying this, to create effective policies with indigenous people, Mãori, the process through which it is designed should be inclusive of indigenous people (Lowry \& Simon-Kumar, 2017). The Ministerial Advisory Committee on a Māori Perspective's engagement strategy was most definitely inclusive where they met with Māori on their terms, on their Marae utilising their customs and protocols. Although their engagement process was only for creating recommendations and not actual policy, recommendations are an essential part of policymaking that identifies needs and brings forth possible solutions. Furthermore, Māori participation within their engagement process was unprecedented, giving them an extensive view of what Māori truly felt about the Department of Social Welfare. Also, what Māori felt was needed to make a difference for Māori, albeit only minimally implemented and largely disappointing. As such, to have effective engagement and 
record the data gathered from that engagement with integrity is not enough. For Māori policy to be less disappointing for Māori, it must also follow through in its implementation phase.

\subsection{The current Government's mandate on the development of Māori responsive policy}

Labour's 2020 election campaign outlined their Māori Manifesto, which recognised that many governments before now have aimed to improve Māori needs, but they claim to work differently from previous governments (Labour Party, 2020 (b)). As discussed earlier in this thesis, although there have been extensive policies that affect Māori, none have made a dent in the statistical disparities between Māori and non-Māori.

As with their last term in government (2017 - 2020), Labour aims to be a better Treaty Partner, working alongside Māori within Te Ao Māori to ensure better outcomes for Māori. To do this, there are two specific organisations whose focus is on: Māori development - Te Puni Kōkiri, and Māori Crown Relations - Te Arawhiti.

Te Puni Kōkiri - The Ministry of Māori Development's aims to support this mandate by promoting, '...Māori achievement in health, training and employment, education and economic development; and to monitor the adequacy of the State sector's services to Māori.' (Te Puni Kōkiri, 2019). Their key focus, as stipulated within their Strategic Intentions 2018-2022, is the importance, '...for government to place Māori needs and aspirations front and centre of its thinking, to focus on opportunities for Māori development and to be open to community-led innovation.' (Te Puni Kōkiri, $2018(a))$.

Te Arawhiti - The Office for Māori Crown Relations, established in 2018, is focused on strengthening Māori Crown Relations. Where the Māori policies of previous governments have failed to meet the needs and desires of Māori (Humpage L. V., 2002), Te Arawhiti have published four documents in particular which aim to aid the government and government organisations to be a better Treaty partner. Two of the documents are the Māori Crown Relations Capability Frameworks for the Public 
Service: One to increase individual capability (the Individual Capability Component - ICC) (Te Arawhiti - The Office for Māori Crown Relations, 2019 (a)), and the other to improve organisational capability (Organisational Capability Component - OCC) to affect a significant culture change across all government organisations (Te Arawhiti - The Office for Māori Crown Relations, 2019 (b)) such as the organisational changes that MSD aims to achieve. The $3^{\text {rd }}$ and 4 th documents are the framework (Te Arawhiti - The Office for Māori Crown Relations, 2018 (a)) and guidelines (Te Arawhiti: The Office for Māori Crown Relations, 2018 (b)) for government organisations to utilise when engaging with iwi, hapū and whānau. Where previous Māori policies have fallen short of Māori expectations, these four documents encourage the government and government organisations to move beyond tokenism, which is a superficial effort towards integrating Te Ao Māori (Hollis-English A. N., 2012 (a)) or transplanting a '...Western approach into a Māori context.' (Morris \& Alexander, 2017). Tokenism only perpetuates scepticism among Māori and, in turn, their unwillingness to participate. However, these four documents aim to dispel notions of tokenism, increase the cultural capability of the public service, and engage with Māori not as the benevolent overseer (Swain, 1987) but as a partner.

What is true is that there has been a lengthy but steady evolution of Māori policy from the destructive nature of integrationist or assimilationist type policymaking (Swain, 1987), towards policy development that requires engagement with Māori; considers their cultural needs; and allows for a Māori self-determination to deliver services to Māori. However, Māori policy has now evolved even further towards true partnership, working alongside Māori to affect government organisational change such as the changes that have been implemented within MSD, which I will elaborate on in the next chapter. A change in the focus of government organisations also affects a change in the expectations and criteria that they set for NGOs to access contracts and funding. Therefore, it is now a requirement for even non-Māori NGO's to attain Māori cultural competency (Ministry of Social Development, 2020 (b)). As with WellStop, which I will elaborate on in Chapter 4, it affects organisational cultural change for NGO's as well.

\subsection{Conclusion}


This chapter aimed to discover 'Why' organisations are adopting Māori Responsive policies. Answering why organisations require policies that are responsive to Māori can be identified in two distinct areas.

\section{Statistical disparities}

Statistical data is a key influence for developing and monitoring government social and economic policies (Janssen \& Forbes, 2014). From a historical perspective, the disparities between Māori and non-Māori and the highlighting of the social needs of Māori have been recognised and recommended upon in many historical reports. Some of which have been recognised in policy that affects Māori. However, none have significantly impacted the social indicator statistics for Māori, implying that policy has not addressed Maori needs so far. New policies are required that are significantly different and are responsive to the needs of Māori to be able to reduce the disparities.

\section{The evolution of Māori policy}

Māori social-economic conditions, child homicides and political movements have been highly publicised, which is a factor that influences policy change (Weible, 2018; Zahariadis, 2005). The struggle for self-determination has influenced a lengthy but steady evolution of Māori policy from the destructive nature of integrationist or assimilationist type policymaking that imposes solutions upon Māori, to a devolution of powers and resources to Māori (Belgrave, 2014) that allows for a self-determined administration of services to Māori albeit with imposed criteria set by Government. This has progressed further to effective engagement with Māori that considers their cultural needs, albeit with a lack of follow-through to implementation. Tino Rangatiratanga, the right to selfdetermination is still an influence that affects policy today (Barrett \& Connolly-Stone, 1998; Wihongi, 2010). Now Māori policy has evolved even further still towards true partnership, working alongside Māori to affect government organisational change, encompassing Māori mātauranga (knowledge) and ethical/behavioural values. This calls for policies that are responsive to Māori by endorsing inclusivity, encouraging participation, and fostering the people's voice that the policy is written for.

Here is what we have learned so far about how Māori policymaking has been approached in the past, the criticisms made and indicators of best practice. 


\section{Māori policy should incorporate mātauranga Māori}

The success of Kaupapa Māori education, being fully emersed in Māori values, culture and tīkanga, validates kaupapa Māori as an intervention strategy (Pihama, Smith, Taki , \& Lee, 2004, p. 35). It also supports the idea that Māori policy should be anchored in mātauranga Māori, such as Māori values and tīkanga, which form the basis of the Māori worldview (Awatere \& Harmsworth, 2014). Also, tokenism, described as transplanting a '...Western approach into a Māori context.' (Morris \& Alexander, 2017) and a superficial effort towards integrating Te Ao Māori (Hollis-English A. N., 2012 (a)), is a factor that perpetuates scepticism. Morris \& Alexander (2017) suggest that avoiding tokenism involves utilising mātauranga Māori in its correct cultural context and begins with an understanding of Māori culture, values and mātauranga, and maximising inclusiveness (Morris \& Alexander, 2017). Therefore, Māori policy needs to begin with an understanding of Māori culture, values and mātauranga to ensure that its use moves beyond the superficial.

\section{Māori should be involved in policy decision-making and leadership}

Policies of integration or assimilation forced Māori to conform to colonial settler culture and deliberately undermined Māori cultural values and tīkanga (Williams D. V., 2019). While seemingly benevolent (Swain, 1987), these policies were not founded on the premise of partnership as agreed to in the Tiriti o Waitangi, but instead are imposed solutions originating from a Eurocentric, monocultural perspective (Hill R. S., 2010). Combined with neoliberalism, these policies were destructive for Māori. So much so that Māori are still affected negatively by them today. Bargh (2016) discusses that part of this can be equated to minimal or lack of representation of Māori in the policy decision-making process. Māori policy therefore should be made where Māori are involved in all policymaking processes. Meaning that Māori should not only be consulted and engaged with, but for true partnership, they should also be policy decision-makers. This will ensure that policies move beyond the superficial, are anchored in mātauranga Māori, and a Te Ao Māori ethos is integrated into every aspect of Māori policymaking.

\section{Te Ao Māori engagement processes should be utilised when engaging with Māori}


The struggle for Māori to be truly heard and adhered to has been a gruelling journey since before the signing of the Treaty. Mãori have raised their voices in protest and within government attempting to instigate change from the inside. The lack of a Māori voice within policy decisionmaking is therefore just a continuation of imposed solutions, as opposed to solutions that are designed in partnership, thus aiding the growth of scepticism and distrust about whether Māori feel they are truly being heard (Smith L. T., Decolonizing Methodologies: Research and Indigenous Peoples, 2006 (a), p. 107). While all Māori do not share such scepticism, it most definitely exists. Unfortunately, a mindset of scepticism means that any form of engagement with Māori is not met with openness and the expectation of a better future but rather with bitterness and doubt (Tolich, 2002).

The Māori Perspective Advisory Committee engaged with thousands of Māori throughout the country to gain a full view of Māori experiences with the Department of Social Welfare for the Puaote-Ata-Tu report. Their engagement process involved meeting with Māori on their own terms in a Marae setting. They believed that engaging with Māori face to face was a traditional approach that would ensure Māori would respond (Department of Social Welfare, 1988, p. 17). To engage with Māori in a Marae setting requires an understanding of mātauranga Māori, tīkanga and kawa. The Committee stated, 'The people certainly grasped the opportunity to voice their concerns, criticisms and grievances.' (Department of Social Welfare, 1988, p. 20). The Committee tried to address as many of the issues highlighted by Māori within the report. Puao-te-Ata-Tu is still viewed as an instrumental document for transformational change for Māori (Boulton, Levy, \& Cvitanovic, 2020). However, through lack of implementation, it remains a disappointment to Māori today. From this, we can say it is imperative to the Māori policymaking process to meet with Māori on their terms, utilising mātauranga Māori and tīkanga to ensure full participation of Māori. However, it is equally essential to ensure that the voices of those who have been engaged extend into the implementation process. Achieving this will dispel much of the bitterness and doubt surrounding policymaking, allowing for a more open process.

Chapters 3 \& 4 will provide an examination of MSD's and Wellstop's Māori policies. I will use what has been discovered about historical Māori policymaking to analyse the potential of MSD and WellStop's development of Māori policy. 


\section{Chapter 3: The Ministry of Social Development}

MSD is one of the largest government organisations in New Zealand, is a leader in social policy providing policy advice across the social sector and delivers a large number of social services for New Zealanders of all ages (Ministry of Social Development, n.d.).

This chapter aims to identify how MSD is implementing their Māori policies by examining their policymaking process. In section 1, I provide a short review of MSD's current Statement of Intent 2018-2022, highlighting MSDs new strategic direction Te Pae Tawhiti. Each government organisation, such as MSD, must present a Statement of Intent to the Treasury Department that outlines its goals and objectives. Each Strategic Intention must also be agreed to by their respective Ministers, which means that the goals and objectives must align with the aspirations of the current government. Examining MSD’s Tauākī Whakamaunga Atu: Statement of Intent 2018-2022 will help build an understanding of MSD's overall purpose and goals for Māori. This sets the foundation for Section 2, which discusses the development of Te Pae Tata - MSD's Māori Strategy and Action Plan. This section also discusses Hohepa Patea, whose interview provides deeper insights into Te Pae Tawhiti and Te Pae Tata. I conclude this chapter with some insights from MSD's policymaking process and an analysis of the potential of MSD's Māori policy development.

This chapter summarises much of the information within the $2018-2022$ Statement of Intent, the information obtained within Hohepa's interview and the finalised Te Pae Tata document. It was essential to preserve this information in as much of its original form to identify the essence of what MSD is trying to achieve concerning Māori responsiveness; and to demonstrate MSD's ability to be true to the voices of those that they engaged with within the final Te Pae Tata document. Most importantly, it was necessary to be tika me te pono to Hohepa's narratives that capture the māuri and deeper, meaningful motivations behind Te Pae Tata's development. As the Primary Principal Māori Advisor, he was the driver and influencer in the interpretation of, and application of, the external influences coupled with a historical need to do better and place whānau at the centre, making them the primary focus. 


\subsection{MSD's Tauākī Whakamaunga Atu: Statement of Intent 2018-}

\section{2}

'Unuhia te rito o te harakeke

Kei hea te kōmako e kō?

Whakatairangitia, rere ki uta, rere ki tai;

Ui mai ki ahau, He aha te mea nui o te $a o$ ?

Māku e kīatu,

He tangata, he tangata, he tangata.
If you remove the central shoot of the

flaxbush

Where will the bellbird find rest?

Will it fly inland, fly out to sea, or fly

aimlessly;

If you were to ask me,

What is the most important thing in the world?

I will tell you,

It is people, it is people, it is people.'

(Ministry of Social Development, 2018 (d), p. 3)

MSD released its most recent Statement of Intent in July of 2018, which begins with the whakatauki Unuhia te Rito. This whakataukī expresses the importance of caring for whānau. This whakatauki, attributed to Meri Ngāroto of Te Aupōuri (Henare P., 2016), uses the flax bush's care (a valuable resource for Māori) and the bellbird who feeds on the flaxbush flower, as a metaphor that demonstrates the importance of caring for people. It is a fitting beginning for a government organisation whose purpose is to;

'Manaaki tangata, Manaaki whānau We help New Zealanders to be safe, strong and independent.' (Ministry of Social Development, 2018 (d), p. 17).

MSD promises that as an agency of the Crown, they intend to uphold the principles of Te Tiriti o Waitangi, work with Māori to ascertain the best ways to assist Māori to achieve their aspirations (Ministry of Social Development, 2018 (c), p. 3), and focus on improving equity and equality for Māori (Ministry of Social Development, 2018 (c), p. 13). They also discuss the development of MSD's Māori strategy, which aims to '...embed a Māori world view into the DNA of the Ministry...' and enhance their responsiveness to Māori (Ministry of Social Development, 2017, p. 27). 


\section{Te Pae Tawhiti - Our Future}

'Ko te pae tawhiti

Whāia kia tata,

Ko te pae tata

Whakamaua kia tina
Seek out the distant horizons,

While cherishing

Those achievements

At hand.'

'This whakatauki lifts our view to a new horizon but keeps us focussed on the changes that we need to make today. '

'To ready ourselves for the future, thrive as an organisation and support our communities, our organisation needs to make three key shifts, which collectively we refer to as Te Pae Tawhiti-Our Future.'

MSD's Statement of Intent introduces MSD's new strategic direction Te Pae Tawhiti which presents three key shifts, Mana Manaaki, Kotahitanga and Kia Takatū Tātou. The key shifts focus on MSDs service culture, developing strong industry partnerships and the importance of MSD's role in New Zealand's social and economic development.

\section{The Three Key Shifts}

Key Shift One: Mana Manaaki - A positive experience every time

'We will be warm and welcoming to all New Zealanders. We will listen with respect and compassion and be open and fair.'

(Ministry of Social Development, 2018 (d), p. 20)

MSD's first key shift focuses on how staff add value to the experience faced by clients. Here, MSD impresses that their staff must have adequate cultural competence

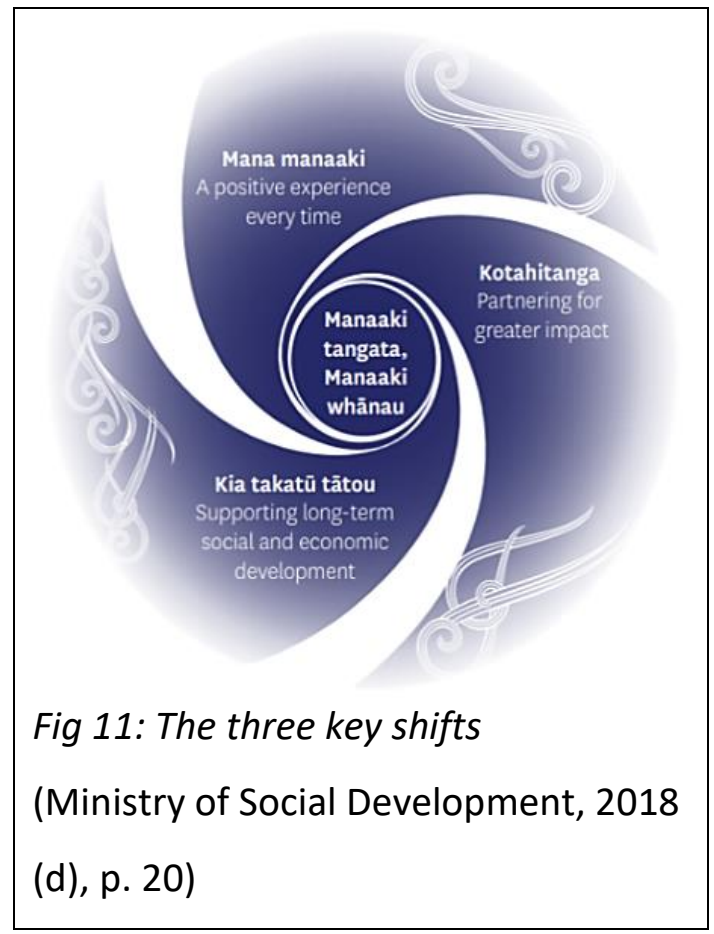


so that culture or ethnicity is not a barrier to providing clients with the support they need (Ministry of Social Development, 2018 (d), p. 21).

\section{Key Shift Two: Kotahitanga - Partnering for greater impact}

'We are stronger when we work together. Strength comes from working collectively with others - government agencies, whānau, families, hapū, iwi, providers and communities.'

(Ministry of Social Development, 2018 (d), p. 21)

The second shift is about how MSD can work better with others, building strong relationships with partners who will assist in the creation of better outcomes for clients. They aim to strengthen their connections with the wider social sector, other government organisations and NGOs, whānau, hapū, and iwi to connect clients with the best services to meet their needs (Ministry of Social Development, 2018 (d), p. 22).

\section{Key Shift Three: Kia Takatū Tātou - Supporting long-term social and economic development}

'We will look to the future and ready ourselves in the here and now. We will take a longterm strategic approach to community, regional and economic development.'

(Ministry of Social Development, 2018 (c), p. 23)

The third shift has a future focus on the journey to come. MSD describes that by understanding the future directions of the economy and society's needs, they can better equip New Zealanders to participate positively in their communities as part of an '...inclusive and prosperous New Zealand' (Ministry of Social Development, 2018 (d), p. 23).

Te Pae Tawhiti's three key shifts of Mana Manaaki, Kotahitanga and Kia Takatū Tatou are a clear move towards meeting the Ministry's obligations under the Tiriti o Waitangi. This is not just because they are Māori kupu but also because the concepts behind the three key shifts encompass the Treaty Principles of Partnership, Protection and Participation. 


\begin{tabular}{|c|c|}
\hline Principles of the Te Tiriti o Waitangi & Te Pae Tawhiti three key shifts \\
\hline $\begin{array}{l}\text { Partnership } \\
\text { 'interactions between The Treaty partners } \\
\text { must be based on mutual good } \\
\text { faith, cooperation, tolerance, honesty and } \\
\text { respect.' } \\
\qquad \text { (Aotearoa New Zealand Association of } \\
\text { Social Workers, n.d. (c)) }\end{array}$ & $\begin{array}{l}\text { Kotahitanga } \\
\text { 'We are stronger when we work together. } \\
\text { Strength comes from working collectively with } \\
\text { others - government agencies, whānau, families, } \\
\text { hapū, iwi, providers and communities.' } \\
\qquad \text { (Ministry of Social Development - Te Manatū } \\
\text { Whakahiato Ora, } 2018 \text { (c), p. 22) }\end{array}$ \\
\hline $\begin{array}{l}\text { Protection } \\
\text { 'government must protect whakapapa, } \\
\text { cultural practices and taonga, including } \\
\text { protocols, customs and language.' } \\
\text { (Aotearoa New Zealand Association of } \\
\text { Social Workers, n.d. (c)) }\end{array}$ & $\begin{array}{l}\text { Mana Manaaki } \\
\text { 'We will be warm and welcoming to all New } \\
\text { Zealanders. We will listen with respect and } \\
\text { compassion and be open and fair.' } \\
\text { 'Our people must have adequate cultural } \\
\text { competence to ensure that culture and/or } \\
\text { ethnicity is not a barrier to providing optimal } \\
\text { service and support.' } \\
\quad \text { (Ministry of Social Development - Te Manatū } \\
\quad \text { Whakahiato Ora, } 2018 \text { (c), p. 21) }\end{array}$ \\
\hline $\begin{array}{l}\text { Participation } \\
\text { 'this principle secures active and equitable } \\
\text { participation by tangata whenua.' } \\
\text { (Aotearoa New Zealand Association of } \\
\text { Social Workers, n.d. (c)) }\end{array}$ & $\begin{array}{l}\text { Kia takatū tatou } \\
\text { 'We will look to the future and ready ourselves in } \\
\text { the here and now. We will take a long-term } \\
\text { strategic approach to community, regional and } \\
\text { economic development.' } \\
\text { '... we can help people live the lives they aspire to } \\
\text { as part of an inclusive and prosperous New } \\
\text { Zealand.' } \\
\quad \text { (Ministry of Social Development - Te Manatū } \\
\quad \text { Whakahiato Ora, } 2018 \text { (c), p. 23) }\end{array}$ \\
\hline
\end{tabular}




\section{Summary}

Generally, MSD's statement of intent and Te Pae Tawhiti encompasses their larger responsibility towards all New Zealanders. However, there are some important statements that pertain to their responsiveness to Māori, such as their commitment to being a better Treaty partner and 'embedding a Māori world view into the DNA of the Ministry. Another important factor is the inclusion of mātauranga Māori, namely the inclusion of whakataukī that reflects and grounds MSD's intentions in a Te Ao Māori focus, and the use of the Māori values of mana manaaki and kotahitanga for two of the three key shifts. The focus of the key shift Mana Manaaki correlates with Mead's (2016) suggestion that manaaki is considering the welfare of others and possessing and utilising adequate resources (including knowledge) to care for them. This confirms that Mana Manaaki has been used in a context that corresponds with a Te Ao Māori perspective. As is the case with Kotahitanga, which from a Te Ao Māori perspective denotes '...consensus, respect for individual differences and participatory inclusion...' (Awatere \& Harmsworth, 2014).

The key shifts of Mana Manaaki, Kotahitanga and Kia Takatū Tatou are also a clear endeavour towards meeting the Ministry's obligations as a Treaty partner as the concepts behind the three key shifts encompass the Treaty Principles of Partnership, Protection and Participation. Came, O'Sullivan \& McCreanor (2020) discuss the utilisation of the Treaty as a framework for policy evaluation like the implementation by MSD in developing the three key shifts.

The Treaty principle of Partnership requires that interactions between The Treaty partners, namely Government and Māori, must be based on mutual good faith, cooperation, tolerance, honesty and respect (Aotearoa New Zealand Association of Social Workers, n.d. (c)). The key shift of 'Kotahitanga in Te Pae Tawhiti indicates that MSD will work collaboratively with whānau, hapū and iwi to achieve better outcomes for Māori (Ministry of Social Development - Te Manatū Whakahiato Ora, 2018 (c), p. 22).

The principle of Protection requires that the government not only passively protects or 'allows' Māori the right to retain their cultural belief systems and participate in cultural practices. They must also actively protect Māori cultural values such as whakapapa (genealogy), cultural practices and taonga, including protocols, customs and language (Aotearoa New Zealand Association of Social 
Workers, n.d. (c)). From MSD's perspective, 'Mana Manaaki' requires that Ministry staff be culturally competent to understand the needs of Māori and reduce cultural barriers that prevent clients from getting the help they need (Ministry of Social Development - Te Manatū Whakahiato Ora, 2018 (c), p. 21).

The principle of Participation requires that the government secure active and equitable participation by tangata whenua (Aotearoa New Zealand Association of Social Workers, n.d. (c)). The final key shift, 'Kia takatū tatou', requires that MSD take a futuristic strategic approach to the economic development of New Zealand, to help New Zealanders to live the lives that they aspire to, to be willing participants in that social and economic development (Ministry of Social Development - Te Manatū Whakahiato Ora, 2018 (c), p. 23).

It is honourable that MSD focuses on how it works with Māori whānau. MSD's mission and vision for Māori outline the change of mindset they wish to have. Section 2 will discuss Te Pae Tata, MSD's Māori Strategy and Action Plan, which sets out 'How' MSD will achieve the goals set out in Te Pae Tawhiti.

\subsection{Te Pae Tata - Māori Strategy and Action Plan}

'Ka huri te kei o te waka

Kia hoe ngātahi

Ki te whai ao

Ki te ao marama
The waka turns towards the distant horizon

Let us make headway and paddle as one

Through the glimmer of dawn

To the break of day'

(Ministry of Social Development, 2019 (g))

This section examines the development of Te Pae Tata, MSD's Māori Strategy and Action Plan. It includes excerpts from Hohepa Patea's interview to identify how the statement of intent and strategic direction should be accomplished. It will discuss MSD's development and strategic focus toward embedding a Māori worldview into the DNA of the Ministry, revealing that MSD has worked 
to include more mātauranga Māori, Māori leadership guidance and a focus toward a change system for Māori whānau.

\section{Hohepa Patea: The Development of Te Pae Tata}

During this thesis journey, I interviewed Hohepa Patea, the Principal Māori Advisor for MSD and the project lead for Te Pae Tata. He provided insights into the development of Te Pae Tata, MSDs Māori Strategy and Action Plan. He discussed the statistical disparities between Māori and non-Māori. He expressed Te Pae Tata's importance in meeting the Ministry's obligations as a Treaty partner and working differently with Māori to achieving better outcomes for Māori from a statistical standpoint. He also mentions that Te Pae Tata has been developed with the intent that it will endure through future statements of intent and changing governments.

\section{Te Pae Tata - The Waiata}

Our discussion began with Hohepa providing a breakdown of their new waiata, Te Pae Tata. While there is a copy of the song in the final release of Te Pae Tata, here l'd like to reflect on the words of Hohepa, who provided a breakdown of the original lyrics, which speaks to the 'why' and the mauri behind the development of Te Pae Tata;

'Te Pae Tata

Ko te ara ki te pae tawhiti ko

te pae tata

Kia ū ki ngā hiahia a te Rangihau mā

I takiri i te ata, i para te huarahi

Hei oranga mō te iwi whānau
The way to the future is paved for today's achievements

That's acknowledging Puao-Te-Ata-Tu, hold fast to the desires of John (Rangihau) and his team.

They who broke the dawn and laid the path

Māori prosperity and wellbeing strengthens us all. Okay, it's not just about, don't get me wrong, first and foremost it's 
about Māori, but whatever we do actually contributes to a greater sense of purpose

Ka huri te kei o te waka ki te pae tawhiti

Kia hoe ngātahi ki te pae tata

Ki te whai ao, ki te ao mārama

Ko te oranga o te pā harakeke

Te mea nui kia tupu mai te rito

Kia puta mai i ngā hua

Kia tau mai te Kōmako

Whakatairangitia rere ki uta, rere ki tai
Turn the waka or turn the bow, toward the distant horizon

So Te Pae Tata is actually about family, together, being of one, uniform but that's about tikkanga, that's about everything, so that we may paddle together and make headway...

to the dawn light, to the world of light

This is about acknowledging the other whakataukī Unuhia te rito...

...so those are about the three key shifts in there that we need to do to work differently with Māori. The health and wellbeing of the flaxbush

Is crucial for the growth of the centre shoot

allows the flax to flower

and in turn provide the bellbird with somewhere to settle. So that's about whānau settling cause right now they are unsettled

it flies out to sea and inland it flies aimlessly and that's our whanau at the moment. How do we help them to settle? Our role is to provide the services, support, 
whatever it takes to know there are better outcomes for Māori.'

(H. Patea, personal communication, May 10, 2019)

Although the waiata had only just been completed at the time of the interview, it provided an overview of Te Pae Tata. It acknowledges the historical leaders who paved the way to enable those of us today to work together to reach the goal on the distant horizon, which overall is utilising mātauranga Māori to work differently with Māori and to ensure the wellbeing of whānau.

\section{Māori Leadership}

Bargh (2016) discusses a lack of representation of Mãori in the policy decision-making process. In stark contrast, MSD has ensured that there is appropriate Māori representation within the decisionmaking process through the establishment of the Māori Leaders Forum and the Māori Reference Group. These groups provide mātauranga Māori expertise and drive the implementation of Te Pae Tawhiti and the development of Te Pae Tata (H. Patea, personal communication, May 10, 2019). Hohepa stated:

'...we're at the epicentre of the organisation we're closest to the decision-makers and to the Minister, we are advocates. As Māori, we are advocates here for everyone else out there in the regions, so we (leadership) need to be doing a good job to making sure that we're providing better outcomes for our people at the frontline that are serving whānau. So that's important.'

(H. Patea, personal communication, May 10, 2019)

Hohepa (Personal communication, May 10, 2019) explained that for Te Pae Tata to succeed, it was necessary to have strong governance made up of prominent Māori leaders from within MSD, the Māori Leaders Forum, and the community, the Māori Reference Group. The Māori Leaders' Forum comprises approximately 35-36 Māori leaders from within MSD. It is chaired by Marama Edwards, who reports directly to Viv Rickard, the Deputy Chief Executive (DCE) of Service Delivery for MSD. The group is responsible for providing the vision and scope of the project, reviewing the project as it progresses and providing authorisation for any developments and advancements. The Māori Reference Group is chaired by prominent Te Arawa leader Roku Mihinui and includes eight other 
highly recognised Māori leaders from around New Zealand (E Tu Whānau, n.d.). The Māori Reference Group represent Māori interests and provide leadership regarding Te Ao Māori and Government. They have been instrumental in providing strategic and cultural advice for the development of Te Pae Tata. Hohepa was quite proud that MSD had such strong Māori leadership to drive these new Māori policies from the top down. He described the leadership as the Kaiurunui of the waka that chooses the direction and leads from behind, pushes their people forward and is accountable for the safe delivery of all those aboard the waka.

\section{Investigating MSD's historical and current Māori policy initiatives}

Before the engagement process began, Hohepa advised that it was necessary to investigate historical recommendations and policies to understand what has been done in the past. He stated that they examined many different documents. But, the document that he felt was the most important to acknowledge was the recommendations of John Rangihau and the Ministerial Advisory Committee on a Māori Perspective found in Puao-Te-Ata-Tu. Equally important was the need to understand what Māori policies and programmes already existed. Therefore, Hohepa and other prominent Māori leaders of MSD travelled throughout New Zealand, visiting service delivery offices, contact centres and processing units to understand the Māori initiatives that already existed within MSD.

\section{Engagement with Whānau, Providers and Staff.}

'Everything in it (Te Pae Tata) has been informed by our people. Those that serve our people, our whanau, the providers, communities, hapu, iwi and whanau. Everything's been informed by that and by government agencies.'

(H. Patea, personal communication, May 10, 2019)

Hohepa and other members of MSD's Māori Leadership travelled to several different offices throughout New Zealand to engage with Māori clients (Whānau), their Ministry funded service providers (Providers), and the staff of MSD (Staff). The purpose was to take stock of what services were currently available to whānau, hapū and iwi, how effective those services are, what MSD does well and what they could be doing better. 


\section{Engagement with Whānau}

'Hey, you're getting the voices of our people that's gonna affect how, it's gonna inform the development of our system. To improve outcomes for Māori.'

(H. Patea, personal communication, May 10, 2019)

Hohepa and other Māori leaders met with 35 Māori clients from throughout the Wellington Region comprised of both male and female of various ages, and received various types of assistance from MSD. Their respective iwi affiliations were Ngai Tahu, Tuhoe, Ngati Toa, Ngati Kahungunu, Ngāpuhi, Tainui, Maniapoto, Ngati Raukawa and Te Aroha (Appendix D). This denotes the importance of engagement with diverse identity groups within Māoridom (Sibley \& Houkamau, 2013).

During their engagement with Whānau, they utilised several traditional processes listed here with an explanation of its meaning and purpose.

They began with hariru/hongi (greeting) at the door. Hariru/hongi - is a tīkanga formality of sharing hau (breath). It is a process that transcends the tapū of personal spaces (Mead, 2016), opening the door for closer communication. Whakawhanaungatanga - is a process of forging relationships through shared experiences (Mead, 2016, ch. 3, p. 8).

Following the greeting, Hohepa initiated a karakia and mihi whakatau to start their hui. Karakia are central to Māori beliefs and are utilised in a wide range of contexts (Mead, 2016). In this case, the karakia created an āhurutanga (safe space) to proceed. Mihi Whakatau are similar to pōwhiri. However, they are more informal and are generally utilised in a non-marae setting. Utilising the informal mihi whakatau process helped solidify the unconscious understanding of āhurutanga.

Following the mihi whakatau and karakia, they had morning tea. Again, sharing a meal or morning tea is a process used in Māori culture to whakanoa. Like karakia, it is the process that shifts one from tapū to noa (Moorfield, 2003-2019), or as Hohepa so aptly puts it, from a place of vulnerability to a place of safety (Personal communication, May 10, 2019). 
During the morning tea, they engaged in whakawhanaungatanga, a process of connecting through the sharing of stories of their origin and what is valuable to them (Justice, 2018).

The seating arrangements were around a table seated in a circle. Kanohi kitea/Kōrero porowhiti (a face seen) places importance on meeting face-to-face, which forges and strengthens relationships (Mead, 2016, ch. 11, p. 17). Sitting in a circle creates a sense of community and promotes inclusiveness (Tūtira Mai NZ, n.d., p. 17).

As mentioned, each of these processes creates a safe space, inclusiveness, builds rapport and connection. Hohepa stated that by the time they started the engagement portion of the hui;

'And all of a sudden, guess what? Everything was already open. Trust and validation was already there. We'd already done that. We'd already done the mana part, you know, we'd already done on board together.'

(H. Patea, personal communication, May 10, 2019)

At the end, they gave the participants a koha to acknowledge and thank them for their participation, their valued contribution to how MSD will deliver services in the future.

During this engagement, Hohepa and the other leaders asked the Whānau 'What does MSD do well?', 'What could MSD do better?' and what are their aspirations. Although some of their responses about what MSD could do better were 'colourful' (H. Patea, personal communication, May 10, 2019), their answers were open and thoughtful. Following the engagement, MSD met again with these Whānau to let them know what they had heard. Their responses were recorded in the MSD's document 'Our Strategy - Our Voice (Whānau)' (Appendix D). They provided feedback about the importance of Te Tiriti o Waitangi, raised issues about Work and Income office environments, how they were treated by MSD staff, about MSD processes and their aspirations.

Hohepa asked the Whānau how they felt the engagement went. He stated that their feedback was that of thankfulness, so much so that some were tearful with gratitude, others didn't want to leave. They received heartfelt comments like;

'You're the first people that's ever asked us actually what we wanted. People normally talk to us like we're kids.' 
'We've never had anyone ask us what we thought.'

(H. Patea, personal communication, May 10, 2019)

Hohepa stated that they learned to be more whānau-centred through this process, for example, organising engagement meetings between 10 am and 2 pm to allow whānau time in the morning and afternoons to manage their families before and after attending.

With regards to using Māori processes of engagement, Hohepa advised that;

'...things that you and me (Māori) might take for granted, it's fricken gold to these people.'

'...we were humbled because it wouldn't have happened if they hadn't have opened up. But we went through our (Māori) process cause we always trust in our process, cause this is how we manage our high levels of uncertainty on the marae...'

(H. Patea, personal communication, May 10, 2019)

\section{Engagement with Providers}

Hohepa and the Māori Leaders met with approximately 10 Ministry funded service providers for both Māori and mainstream clients throughout New Zealand to gauge their thoughts regarding what MSD did well and what they could do better.

An overview of their responses can be found in the MSD document, 'Our Strategy - Our Voice (Providers)' (Appendix E). The providers' feedback encompassed the importance of Te Tiriti o Waitangi, being trusted and valued, raised issues about the short length of contracts, funding, quality measures, and outcomes that are whānau-focused.

\section{Engagement with Ministry Staff}

Hohepa and the Māori Leaders also travelled throughout New Zealand to various Ministry offices to meet and greet the Staff. Hohepa speaks affectionately of the team of MSD as '...our staff work really hard, the most undervalued and underpaid staff.' (H. Patea, personal communication, May 10, 2019). 
What they found were dedicated Staff who really wanted to help whānau but were restricted in their ability to do so through time restraints and key performance indicator measurements. One of the highest priorities for Staff was to have more time to help whānau, more support for kaumātua and the freedom to do what's right for whānau. Hohepa stated that the visits revealed a severe disconnection between National office and the frontline.

Hohepa and the Māori Leaders also arranged for pop-up stations to be erected throughout MSD offices. The pop-up stations were comprised of posters with specific themes on them, and Staff were provided with stickers to indicate what particular themes they agreed with. The responses from the Staff are recorded in MSD's document 'Our Strategy - Our Voice (Staff)' (Appendix F). Their feedback encompassed their need for collaboration with other agencies to provide better services to Māori and to be able to spend as much time as they need with clients. They also wanted a staff wellbeing package, felt that te reo, Te Tiriti o Waitanga and cultural capability were important and requested development opportunities for Māori staff. They also felt it was important to foster positive relationships with mana whenua.

Hohepa and his team kept staff informed about Te Pae Tata's development throughout the process through email messages and short video clips on MSD's intranet.

\section{Consultation with the wider community}

Once Hohepa and the other leaders had collated the information gathered from Whānau, Providers and Staff, MSD decided it was necessary to seek feedback from the wider community. They released an online survey to gauge responses from whānau, hapū, iwi and providers of social services to Māori and the staff of MSD. They received 5000 responses from the survey, which they analysed and incorporated into the final release of Te Pae Tata, which was released to the public on 26 August 2019.

\section{Summary}

The importance of engaging with Whānau is threefold. Firstly, the gathering of the families' voice gives a first-hand account of the presenting need. Hohepa spoke of how it benefits MSD, more 
importantly, that the whānau felt that they were being included in an important strategy. The fact that the whānau reported that they have never been asked their opinion before reflects a common mindset among Māori of imposed processes, not inclusive ones. Secondly, the Te Ao Māori processes utilised by Hohepa and his team encompass principles of kaupapa Māori research effectively engaging with Māori within Te Ao Māori (Te Arawhiti: The Office for Māori Crown Relations, 2018 (b)) underpinned by Māori philosophies (Smith G. H., 1997) from a Te Ao Māori worldview (Smith L. T., 1999) that enables the quiet or unheard voices to have a place when once they did not. Like the processes utilised by the Māori Perspective Advisory Committee, MSD's engagement process encouraged Māori participation and, as such, should be a precedent for future engagement processes. Thirdly, the inclusion of whānau, provider and staff voices holds weight. Still, there is an added responsibility now to ensure that the integrity of those voices and the dissemination of their content be honoured, respected, and most of all, due recognition given. As previously discussed, the voices of Māori need to extend beyond exceptional engagement. Their voices must also extend into the implemented policy. Therefore, it is important to note that MSD has ensured that the integrity of the voices of whānau, providers, staff and the wider community have been utilised in the finalised Te Pae Tata policy (Ministry of Social Development, 2019 (g)).

As it is for the whānau engagement, so it was for staff, providers and the wider community, threefold. The process used by Hohepa answers the thesis question regarding the implementation and use of tīkanga Māori and Māori knowledge. Hohepa mentioned that this was important to show whanaungatanga to gather the voices of each stakeholder group. From his dialogue, it was evident that a Māori process of engagement was crucial regardless of the group present. Why is this important? Overall, to ensure tīkanga is adhered to. These hōhonu principles highlight Hohepa's ability to walk in a non-Māori space while endorsing a Māori ethos, paving the way and creating an expectation of practice, done with purpose and pride. The insight offered here is the importance of using a Māori process in all engagement.

\subsection{Conclusion}

\section{Defining MSD's policymaking process in the development of Te Pae Tata}


As Te Pae Tawhiti is MSD's strategic direction which sets the goals and objectives for the Ministry and is developed via the mandate and aspirations of the government, this section will focus on the development of Te Pae Tata MSD's Māori strategy and action plan. There are several steps with regards to the development of this Māori policy. While they are numbered for clarity, the steps of MSD's process are in no particular order, and many occurred simultaneously.

\section{Establishing a robust Māori leadership}

Hohepa expressed the importance of having a strong Māori leadership that he describes as Kaiurunui, who directs the waka. Came, McCreanor, Haenga-Collins \& Cornes (2019) discussed the experiences of Māori and Pasifika leaders on health advisory groups which highlighted suspicions of tokenism in terms of including indigenous leaders to '...create an impression of inclusivity rather than have substantive input into policy.' (Came, McCreanor, Haenga-Collins, \& Cornes, 2019). This is clearly not the case with MSD, whose Māori leadership's responsibilities encompass providing cultural guidance concerning the efficacy of the use of mātauranga Māori and tīkanga, and driving the implementation of the policies across the Ministry from the top down. Where Bargh (2016) discusses that the disparities between Māori and non-Māori are resultant from a lack of Māori involved in the decision-making process, the leaders and decision-makers involved in the development of Te Pae Tata are Māori. Therefore, this should be an advancement towards reducing those disparities.

\section{Gaining an understanding of historical and current Māori policy}

As with this thesis, history has significant value in the policymaking context providing background, historical parallels, reference points and new ways of thinking (Haddon et al., 2015). MSD's investigation of governmental and departmental historical and current policies helped define the focus and processes necessary to achieve the aspirations of the Statement of Intent and Te Pae Tawhiti in the development and implementation of Te Pae Tata. For example, utilising Māori processes of engagement similar to those of the Māori Advisory Committee to obtain the voices of Māori but also utilising those voices in the final Te Pae Tata policy. 


\section{Engagement}

The engagement process that MSD has utilised with whānau is vital to note. They selected those that are important to engage with to meet the objectives of the Statement of Intent and Te Pae Tawhiti, which included Māori whānau from diverse iwi, providers, staff, advisory groups and the wider community. I have discussed the cynicism among Māori (Smith L. T., 2006, Hollis-English, 2012) and how this creates disillusionment and an unwillingness to engage (Lundy, 2018). However, Hohepa's utilisation of mātauranga Māori and tīkanga processes in their engagement with whānau helped to dispel those cynical fears. They created an ahurutanga, a safe space for whānau to participate openly and honestly without fear of reprisal. This also aided whānau to feel that they had been heard. I applaud MSD for the level of engagement endorsed by Hohepa Patea. Not only have they engaged well with Māori but had ensured to include the voices of all those that they engaged within the final Te Pae Tata policy. This, I believe, will establish an engagement precedence and should guide future Māori responsiveness policymaking.

\section{The utilisation of mātauranga Māori and Tikanga throughout the development process.}

MSD's publications and Hohepa's descriptions of Te Pae Tawhiti and Te Pae Tata are saturated with mātauranga Māori, te reo, whakatauki, waiata, and tīkanga processes. Whakataukī and waiata are Māori traditional forms of knowledge transference (Hikuroa, 2017). For MSD, they provided the grounding and focus for their Māori policymaking process and service delivery and leadership.

Their engagement utilised tīkanga processes grounded in inclusiveness such as hongi, karakia, mihi whakatau, whakawhanaungatanga, kai, kanohi ki te kanohi and korero porowhiti. There can be no doubt that throughout Te Pae Tawhiti and Te Pae Tata's development, mātauranga Māori and tīkanga have been utilised.

\section{Embedding a Māori world view into the DNA of the Ministry}

'We have already begun to change. We are improving the way we deliver our services to clients. We are improving collaboration with providers, partners and other government agencies. We are forward-facing and looking at how best to support New Zealanders into the future. A lot of change is happening in our organisation, but we remain focused on how we 
work with our clients to help them to be safe, strong and independent. That core purpose will not change - but we will do it better.'

(Ministry of Social Development, 2019 (d))

MSD should be commended for believing in embedding a Māori worldview into the DNA of the Ministry. They have made a considerable effort to try and achieve it. However, as a function of the government, MSD operates from a collective perspective and is responsible for more than just Māori, which has the potential to minimise the indigenous voice. As a Treaty partner and as sufferers of historical trauma, Māori are afforded privileges over and above other ethnicities in New Zealand (Borell, Barnes, \& McCreanor, 2017). However, this contends with the notion of New Zealand as a multicultural society (Smith J., 2010). Therefore, this could mean that MSD's policy is influenced by a Māori perspective but driven from a multi-cultural perspective.

Hohepa Patea's work and kōrero are inspirational. MSD's policies have been developed through consultation and engagement with Māori to respond to negative statistics, trends and meeting Government aspirations. This case study speaks to the formed intent and the steps to implement; however, they themselves are immeasurable. The litmus test can only be measured based on disseminating the policy and interpreting these into practice. If the mauri of this policy comes into fruition, then it is quite possible that the statistics will improve. The scope of this thesis does not include an analysis of the success of MSD's Māori policy. Therefore, further research of the implementation process and the outcomes, to see whether the intent is realised, statistics are reduced, and Māori benefit would be beneficial to reveal the success and achievement of Te Pae Tawhiti and Te Pae Tata. 


\section{Chapter 4: WellStop}

NGOs such as WellStop are situated within the community and are best equipped to respond to the needs of their communities (Ciucescu, 2009). Moreover, they have become a critical component of service delivery on behalf of the public service (Siliunas, Small, \& Wallerstein, 2019). The policies and aspirations of the government's organisations, from whom WellStop attains their funding, greatly influence how NGOs develop their policies (O'Brien, Sanders, \& Tennant, 2009). For this thesis, examining the development of WellStop's Māori policy, Te Kupenga provides a non-Māori NGO perspective of creating Māori responsive policies.

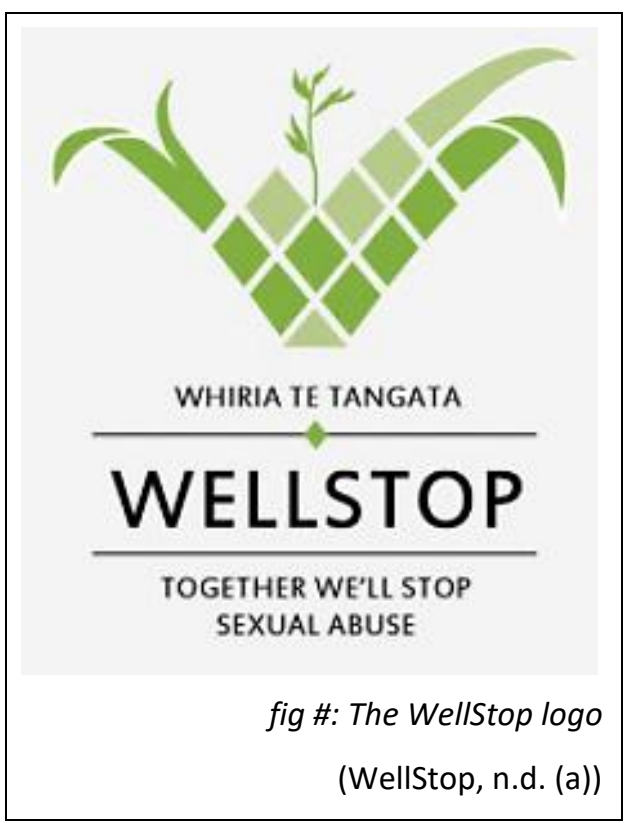

WellStop is a non-Māori NGO specialising in Harmful Sexual Behaviour (HSB) and Sexual Abuse services for children, young people, and adults who either exhibit HSB or are victims of it. Their client's needs are complex, are never just HSB but involve a cluster of issues (Jina \& Thomas, 2013; Siliunas, Small, \& Wallerstein, 2019). Therefore, it is imperative to have staff whose knowledge and experience covers multiple disciplines. WellStop's staff include social workers, counsellors, clinicians, and psychologists situated in 9 offices spread throughout the East Coast and Lower North Island. (WellStop, n.d. (c)). WellStop is also an accredited service provider for Accident Compensation Corporation (ACC), the Department of Corrections (Corrections), Ministry of Health (MOH), MSD and Oranga Tamariki (OT). They also collaborate with many different services such as iwi based social services, survivor/victim agencies, schools and education providers, to name a few (WellStop, n.d. (a)).

WellStop is also one of three partner agencies that make up Trinity Alliance (the Sector) which provides HSB services across New Zealand. WellStop's services cover the East Coast and across the lower North Island, 'Safe Network' covers the upper North Island, and 'Stop' covers the entire South Island. The Sector leadership group known as Trinity Alliance, comprised of senior leadership 
members from each organisation, regularly collaborate on issues that affect the whole sector, such as gaining consistency of practice across the HSB sector. The Kaiārahi Māori - Māori Development Manager (Kaiārahi Māori), is a part of Trinity Alliance and is a key advisor to the application of mātauranga Māori and the development of Māori responsive policies for the Sector.

WellStop recognises that the Treaty of Waitangi instituted partnership relationships between Māori and non-Māori and states that 'The policies and practices of the WellStop programme seek to reflect this.' (WellStop, n.d. (b)). While WellStop provides services to all ethnic and cultural groups, what is highlighted here is an acknowledgement of the unique position that Māori culture has and its importance to WellStop. As such, WellStop's Board and Senior Management aim to develop their Māori policy, Te Kupenga, to embed a Māori worldview across the organisation and be more responsive to the needs of Māori. This aim instigated the search for Māori Leadership to guide the policymaking process. Mark King, whose interview forms part of this chapter, was employed as the operations manager and has now been appointed to the CEO role for WellStop. Mark King encouraged a designated senior management role to be formed, the Kaiārahi Māori. I was employed as the Kaiārahi Māori in July 2019. The Kaiārahi Māori role covers all things Māori/cultural for WellStop which includes everything from the establishment of training, cultural supervision, policy and case consultation, iwi/Māori liaison to the creation and implementation of Māori competencies. Mark King has also encouraged that all organisational and operational policies of WellStop have a Māori lens applied to them.

This chapter will discuss Wellstop's influencers toward the development of Māori policy to identify further reasoning behind why WellStop has developed Te Kupenga. It uses the findings in chapter 2 to examine Wellstop's Māori policymaking process.

You will find that this chapter summarises much of the information that is available on websites, the Kaiārahi Māori progress report and the information obtained within Mark's interview. It was essential to preserve this information in as much of its original form as possible: to demonstrate the overarching purpose of the organisation through WellStop's vision, values, whakataukī and karakia; to identify the factors that influence WellStop to develop their Māori policy; and most importantly to be tika me te pono to Mark's narratives which capture the Māuri and deeper, meaningful motivations behind the development of WellStop's policy. I note that to understand the Māuri of 
WellStop's Māori policy, the voice of Mark was vitally important. Mark and the Kaiārahi Māori were the drivers and influencers in interpreting and applying the external influencers coupled with a historical need to do better and place whānau at the centre, making them the primary focus.

\subsection{WellStop's vision, values, whakataukī and karakia}

\section{WellStop's vision}

As a government organisation, MSD's vision, their Strategic Intention, is based upon the government's aspirations that directly influence their need to create Māori responsive policies. However, WellStop's governance sits with its Board, whose primary goal is for the implementation and success of the organisations' purpose (Bawden, 2008). As such, herein lies a contrasting factor that shows that WellStop's key focus, as a non-Māori NGO, is not primarily to be responsive to Māori but is instead to achieve their vision of building, 'A world in which each person experiences respectful relationships, a strong sense of connection to family, friends and community, and is safe from sexual abuse.' (WellStop, n.d. (b)). Although WellStop's vision is not primarily focussed on being responsive to Māori, they do acknowledge the Treaty '...as an agreement which establishes a partnership relationship between Māori and Tau Iwi in New Zealand.' (WellStop, n.d. (b)). Having said this, Lesley Ayland (WellStop's previous CEO) and Mark King (WellStop's current CEO) had the foresight that to be effective, WellStop needed to reflect the true essence of the principles of Te Tiriti o Waitangi, partnership, protection and participation. WellStop's commitment to the Treaty is embedded within their organisational values, whakataukī and karakia.

\section{Values}

WellStop's values encompass mātauranga Māori values. These are Whanaungatanga - forging quality relationships with others (WellStop, n.d. (b)); Pono - Having integrity and being worthy of trust; Ngākaunui - To be compassionate and consider others' experiences and respond with kindness; Manawanui - Having the courage to traverse the journey from abuse to wellness and working together to change abusive practices; Hiringa - Utilising best practices to achieve the best outcomes for all. 


\section{Whakataukī}

'Whiria te Tangata'

'...weave, or bring together, the people'

(WellStop, n.d. (a))

As stated previously, whakataukī are proverbs or sayings which encompass the themes and directives (Ruru, Roche, \& Waitoki, 2017), warnings, instructions (Metge \& Jones, 1995), wit, wisdom and common sense of Māori (Brougham \& Reed, 2012). 'Whiria te Tangata' is WellStop's Whakatauki that reflects their mission to work together to prevent incidents of abuse until the community is free from sexual harm and abuse (WellStop, n.d. (d)).

\section{Karakia mō te whakawātea o WellStop}

In 2013 the karakia (Appendix G) for WellStop was created by my wife Shea Robin-Underwood and I for the whakawātea of the new wing of their national head office. The karakia, and our assistance, were utilised again in 2015 for the whakawātea of their current national head office. This karakia now acts as a declaration of commitment, dedication, and responsibility that the staff of WellStop place upon themselves to administer services to whānau, hapū, and the wider iwi.

\section{Summary}

Vision, values, whakataukī and karakia have all been developed through the utilisation of mātauranga Māori. This grounds the organisation's focus in mātauranga Māori and supports the development of Māori responsive policies, which is further supported by the foresight of Wellstop's previous and current CEOs to aspire to create Te Kupenga and appoint the Kaiārahi Māori to drive the development of the policy.

\subsection{WellStop's external influencers for creating Māori responsive policies}


As previously discussed, WellStop is a non-Māori NGO whose primary goal is not necessarily to be responsive to Māori but is instead to empower respectful relationships, connect to the community, and keep them safe from sexual harm (WellStop, n.d. (b)). Why, therefore, is WellStop aiming to create a Māori responsive policy/policies? To understand the 'Why?', I examine 3 of WellStop's external influencers for creating such policies; stakeholder expectations, social service accreditation and professional registration.

\section{Stakeholder Expectations}

As a contracted provider for MSD, ACC, Corrections, $\mathrm{MOH}$ and Oranga Tamariki, WellStop must implement policies that meet all its stakeholders' expectations (Freeman \& Mcvea, 2001). NGOs such as WellStop are essential for achieving the government's goals. As such, WellStop's ability to obtain/maintain those contracts is contingent on whether their services are beneficial for achieving those goals (Ciucescu, 2009). The government's current focus on Māori responsiveness is quite prevalent across the public service and is reflected in each government organisation's statements of intent.

As already discussed, MSD's Statement of Intent includes their new strategic direction - Te Pae Tawhiti, and their subsequent Māori Strategy and Action Plan Te Pae Tata, both of which aim to embed a Māori world view into the DNA of the Ministry. ACC's statement of intent $2018-2022$ explains their Māori strategy 'Whāia te Tika' which aims to make a meaningful difference in the lives of Māori by engaging with Māori in culturally appropriate and responsive ways (The Accident Compensation Corporation, 2018, p. 30). Corrections' Statement of Intent 2018 - 2022 focuses on better outcomes for Māori that discusses appropriate cultural services to assist Māori offenders towards rehabilitation (The Department of Corrections, 2018). MOH's Statement of Strategic Intentions 2017 - 2021 discusses appropriate non-government kaupapa services to aid towards their goals for Māori (Ministry of Health, 2017). Oranga Tamariki's Strategic Intentions 2017 - 2022 aim to improve outcomes for Māori children first and foremost, part of which is to ensure services respond to the needs of Māori children and young people (Oranga Tamariki, 2017). It is clear that for WellStop to meet the expectations of and be beneficial in achieving the goals of these government organisations, WellStop must be responsive to Māori and therefore must have a policy or policies that enable responsiveness to Māori. 


\section{Social Service Accreditation Standards and Funding}

As a service that administers service delivery on behalf of government organisations, WellStop is both a recipient of government funding and resources and must contribute to the goals of those organisations (Siliunas, Small, \& Wallerstein, 2019). To operate, NGOs are reliant on the funding that government organisations provide. However, to secure and maintain those contracts, NGOs such as WellStop must meet the accreditation standards set by the government (Ministry of Social Development, 2020 (a)). In 2015, government agencies jointly developed the Social Sector Accreditation Standards (SSAS), which are designed to test the capability and capacity of whether NGOs can safely deliver social services to New Zealanders (Ministry of Social Development, 2020 (a)). WellStop is a Level 2 accredited provider. What is relevant for this thesis is that the Level 2 Accreditation Standards stipulate that NGOs must provide services that are culturally competent (New Zealand Government, 2019 (e), p. 8) and meet the needs of Māori (New Zealand Government, 2019 (e), p. 9). Unfortunately, the pressures of meeting and maintaining accreditation standards and competency measures also influence organisations to ignore crucial problems that clients have because they are not captured by those measures (Siliunas, Small, \& Wallerstein, 2019). However, they compel NGOs to be more responsive to Māori whereby they must have a Māori policy or policies that encompass the integration of mātauranga Māori into their service delivery practices and increase the cultural competency of both leadership and staff.

\section{Professional registration}

A prerequisite for employment with WellStop is that employees must have professional registration for their respective fields of practice or be working towards it. The registering of staff within WellStop is twofold; firstly, the importance of being registered and having registered staff lies in accountability and denotes a level of responsibility that enables confidence in the staff who must have specialised skills and experience to work effectively within the HSB sector. Secondly, it is essential, as professional registration is required for level 2 social service accreditation. The following are only two of many professional registration agencies that require adherence to codes of conduct or ethics. Therefore, WellStop must have staff who are either registered with a professional body that is recognised in New Zealand or are working towards securing their professional registration. Each registration board includes requirements for professionals to be 
culturally competent and places an obligation on employers to provide training and support that enables registered staff to continue to meet their cultural competency obligations. This speaks directly to an influencer of the development of WellStop's Māori competencies to support staff to gain the necessary cultural competency to obtain and maintain their professional registration and the organisation's social service accreditation.

\section{Social Workers Registration Board (SWRB)}

In correlation with the international trend to regulate (Beddoe \& Duke, 2009, p. 785) and professionalise (Hunt, 2017, p. 53) the social work profession, from the $27^{\text {th }}$ of February 2021 , social workers must be professionally registered with the SWRB (Social Workers Registration Board, 2021 (a)). Social workers need to hold a valid practising certificate that must be renewed every year, abide by the code of conduct and undertake continual professional development (Social Workers Registration Board, 2021 (b)). What is essential for this thesis is that to maintain their registration, Social workers must show that they are culturally competent to practise social work with Māori. The SWRB's Māori cultural competency measures state that social workers must demonstrate knowledge of;

'...The Treaty of Waitangi, te reo and tikanga Māori;

articulating how the wider context of Aotearoa New Zealand both historically and currently can impact on practice;

Te Rangatiratanga: Maintaining relationships that are mana enhancing, self-determining, respectful, mindful of cultural uniqueness, and acknowledge cultural identity.

Te Manaakitanga: Utilising practice behaviours that ensure mauri ora with a safe space, being mana enhancing and respectful, acknowledging boundaries and meeting obligations. Te Whanaungatanga: Engaging in practice that is culturally sustaining, strengthens relationships, is mutually contributing and connecting, and encourages warmth.'

(Social Workers Registration Board, n.d. (a))

To ensure that their staff obtain and maintain their professional registration status, WellStop is obligated to ensure that staff are provided with the appropriate resources and support to do so, thus creating the need to develop Māori policies that aid that development. 


\section{New Zealand Association of Counselling (NZAC)}

The NZAC, like the SWRB, is tasked with providing professional oversight and guidance to professionals who are registered with their services. The NZAC encourages staff to be culturally competent when working with whānau, hapū and iwi and includes adherence to the Tiriti o Waitangi. The NZAC also has measures that staff must meet, thus adding their voice of what is 'Culturally competent' when working with Māori. The Objectives of NZAC include, among eleven other statements to;

'Promote effective counselling services that are consistent with obligations under The Treaty of Waitangi'

(New Zealand Association of Counsellors, n.d. (b))

NZAC has developed ten competence areas for NZAC Counsellors which includes;

'Puawananga Kaitiakitanga; Formerly cultural supervision'

(New Zealand Association of Counsellors, n.d. (b))

Section 5.2 of The NZAC code of ethics states:

'Respecting Diversity and Promoting Social Justice

a. Counsellors shall take account of their own cultural identity and biases, and seek to limit any harmful impact of these in their work with clients.

b. Counsellors should work towards bi-cultural competence.'

(New Zealand Association of Counsellors, n.d. (a))

Again, to obtain and maintain their professional registration, practitioners must be Māori culturally competent, which creates the need for WellStop to develop Māori responsive policies that provide the appropriate support and resources for staff to do so.

\section{Summary}

The influencers described above explain the complexity that surrounds the 'why'. Why is it necessary for WellStop to create policies that engage with and are responsive to Māori? Each influencer described here requires that NGOs work towards or attain cultural competence. Cross, Bazron, Dennis, \& Isaacs (1989, p. 13) define cultural competence as '...a set of congruent behaviors, 
attitudes, and policies that come together in a system, agency, or among professionals and enable that system, agency, or those professionals to work effectively in cross-cultural situations.' Furthermore, they inform us that cultural competence is an evolutionary process developed over time through education, opportunity and policy.

The SWRB or the NZAC are non-Māori authorities that represent two of the many voices that have an opinion about what Māori practice and competency looks like. They provide boundaries or criteria that speak to what needs to be included as a practice model. Therefore, cultural competency is a defining factor in developing policies that are responsive to Māori and places a responsibility on policymakers and the leadership of NGOs to ensure that there are appropriate opportunities for cultural support and cultural education for their employees.

The imposition of standards for cultural competency or Māori responsiveness by non-Māori authorities may set up another barrier that could negatively impact Māori. The influence of these non-Māori authorities who demand that Māori engagement exists cannot be easily disregarded. I note that the scope of this thesis does not examine the development of Māori cultural competency criteria and measures. However, the Māori policymaking arena could benefit from such a study, especially since those criteria and standards have the potential to influence good or bad Māori responsive policymaking practice (Siliunas, Small, \& Wallerstein, 2019). These imposed measures and criteria directly influence WellStop with regards to the development of Te Kupenga; however, the decisions about how the criteria will be implemented rests with the leadership of WellStop.

\subsection{Interview with Mark King, the Chief Executive Officer of WellStop:}

The interview with Mark King provided an opportunity to glean insights into the mauri (essence) that underpins WellStop's work and the development of Te Kupenga. Mark King's vision for the inclusion of a Māori worldview means that the influencers mentioned above are filtered through his office and the Kaiārahi Māori role. As such, the interpretation of those influencers are considered 
but not to the detriment of the efficacy of mātauranga Māori in the development of WellStop's Māori responsive policy.

The following are Mark King's words (M. King, Personal communication, August 2, 2019), which speak of what is needed and is reminiscent of the WellStop karakia: of service steeped in the spirit of excellence, trusted and heartfelt, and a service that seeks to help. The win-win scenario here is policies that are based on respect and inclusivity. With this in mind, the first-hand account and perception and guidance from Mark King's voice is the primary influencer of the formation of WellStop's direction and influence in our sector. From a Māori perspective, Mark's values and principles add mana to the Māori policymaking process, which included the appointment of the Kaiārahi Māori.

Firstly, Mark is of Ngāti Pukenga iwi descent. One of 5 children, he grew up in Taranaki from the age of 5 before moving around NZ and then to Australia at 35. He has three children, two sons aged 33 and 30 , and a daughter who is 25 . He has been married to his wife Julie for 35 years. As the Chief Executive Officer of WellStop, he provides leadership and oversight of the effective operation of WellStop. Mark has been employed with WellStop for four years.

Mark believes that Māoritanga has informed his practice by giving him the passion for ensuring that Māori are supported/cared for and empowered to achieve positive outcomes from a Māori perspective taking into consideration rituals, kawa, tīkanga, whānau, hapū and iwi. From Marks' collective experience, WellStop's Māori approach is founded, which includes ensuring that Māori feel included, have a say, and determine their own direction.

Marks' belief in self and his grounding in Māoridom aids the embedding of mātauranga Māori and tīkanga into the organisation's practices. An informed formation of Māori policy for WellStop by leading from the front as a role model, educating and guiding others, to ensure Māori have a voice and a presence in all matters to do with the delivery of quality services.

This is reinforced by Mark's belief that WellStop needs to change by embedding a culture of support, caring with a professional approach within an environment that is led by Māori values. This principle speaks to the Mãori worldview that WellStop will move forward with. The belief is that working in a mātauranga Māori based way is the avenue to bring peoples together. 
Mark believes that the Kaiārahi Māori role is to strategise the short, medium and long- term vision and goals, direct and guide WellStop towards ensuring that the organisation's work is competent, confident and reflects the values of Māori. The strategy includes filtering all influencers voices through this Māori lens (M. King, Personal communication, August 2, 2019). The plan began with the understanding that WellStop required cultural guidance and, therefore, to employ someone specific who has the expertise to guide not only WellStop but also the HSB sector. The Sector's role is to be a united, strong voice that is committed to following and carrying out anything and everything that will enable a culture of change where Māori are leading the change.

Mark believes;

'... a service needs to understand first what, and who are Māori? Where do they come from? Who are they? What's their history? Where do they fit in Aotearoa, New Zealand? What is their importance? You know, I believe we need to understand that first to be effective in determining the right way to deliver a service to somebody, to get the best possible outcome for that person, and we as Māori we're not the same, we're different, we're unique. We live in so many worlds and have so many beliefs, and we care for so many things, and we have a thing which is called Wairua. Some call it a spiritual side, or you know, have their names for it, so all of that stuff to me means, and like I said Vince, simple as understanding when to say it's an assessment, to stop the traditional way of assessment, and to take time out, and not to rush it, and to be sensitive with that, to do all the set up work properly and with respect. Cause once that's done, then anything's possible. But if I don't get that right when I'm engaging with Māori, I know it will never be as good as what it could be.'

(M. King, Personal communication, August 2, 2019)

Here Mark confirms the importance of understanding Māori to identify their needs and to utilise mātauranga Māori processes to provide the best services for Māori.

Mark's perception about the forming of tīkanga and Māori models is;

'...for our manuhiri, our visitors, our clients, our whanau, coming here, whether they're Māori, Chinese, Japanese whatever, even the use of signage to give a message of welcoming and, 'It's okay for you to be here,' you know anything that's gonna reduce the trauma of actually 
having to come to a place where 'I'm not really sure how this is going to go, I'm a little bit nervous, anxious, right down from signage to, see a smiling face, a welcoming face, a nice voice talking to you. It's not hard to do, but at times it seems hard to do.'

'It is agreed that rangimārie peace needs to be brought in, and there needs to be some sort whakarite, some sort of cleansing of the space and so going forward that might need to be something WellStop needs to look at.'

(M. King, Personal communication, August 2, 2019)

This speaks of implementing mātauranga Māori and tīkanga to bring a sense of safety and ensure the space itself is clear of any healing barriers. A more profound thought of practice from a Māori perspective means that Māori responsiveness includes an adopting of traditional practices that support the engagement and building of lasting relationships with whānau, hapū and iwi. This means that Te Kupenga must influence an increase of staff training in recognising and implementing support from a place of understanding Māori tīkanga.

Mark believes;

'To embed a culture of support, caring with a professional approach within an environment that is led by Māori values. I guess in simple and short words, it is an environment that is based around manaakitanga, awhitanga. You know all the 'Tangas' that bring people together and look after people.'

(M. King, Personal communication, August 2, 2019)

Here Mark confirms that embedding a Māori worldview is integral for the organisation's services of creating wellbeing for others.

Mark believes in adding value.

'That. That's how I want WellStop to be. For anybody from the top right to the bottom, from the bottom right up to the top.

For me, coming to WellStop, for me it was about, I guess, giving out or giving away what I knew about Māori and what I believe was good for Māori, starting from a base of waiata 
and karakia and giving kōrero around that with my knowledge that I knew. Because when I first came to WellStop, it was a very, how would I describe it? A place that I couldn't see much Māori. I couldn't feel much Māori. I didn't know what others knew or thought about Māori, so it wasn't obvious to me. It was a nothing really. My immediate thought was, I need to be part of a change process here and lead it as a Māori because naturally, being Māori and a male in the role that I am, people would be looking to me to lead, to guide, and that's actually kind of like a, not taken for granted or tokenism it's just I think within some of New Zealand society that's how it's viewed. Oh, there's a Māori person here they'll be fluent in the reo, they'll be fluent in the tikanga, they can play 'ten guitars' all of that. Say 'oh great, we've got somebody they can do everything from now on.' And, I don't mind that, but I use the term 'Use me but don't abuse me. Understand me before you know me.' You know that kind of kōrero and whakaaro. So that was a real need and want of mine to start developing. Start, you know Vince from knowing one waiata 'Te Aroha', to now knowing I think we have eight waiata now that we can rattle off and kind of everybody knows. To me, that's a big deal. That's a huge thing for me.'

(M. King, Personal communication, August 2, 2019)

Here Mark subtly points out the detriment of tokenism and unrealistic expectations on Māori staff. However, this only informs the need to develop Te Kupenga from a mindset of valuing the importance of mātauranga and cultivating that understanding within the organisation.

Mark agrees that WellStop needs to be a Well - Stop where people get 'Well.' Not only our clients, whānau, hapū, iwi but also our staff. Marks goal is to;

'It can be a real immersion for WellStop, the mainstream provider into service delivery from a kaupapa Māori way. You know, real immersion, a real commitment, a real understanding, a real delivery of those services still within a mainstream framework but equally, there's the possibility of a separate WellStop kaupapa Māori delivered service. Specifically, for Māori clients and whanau, hapu, iwi. I think that's our future, that's where we should be heading. You know we've written down the new legislative act of 7AA. That is forcing us to be thinking more in the lines of what is our responsiveness to Māori. We're forced to do that now, we don't have to think about it and do some tick boxes. That doesn't cut it anymore. So, we have everything coming behind us, pushing us, enabling us, the recent government budget. Look 
at the millions of dollars that have been acknowledged and put into that, the sexual violence sector and within that specifically for kaupapa Māori services. So, here's all the signs, here's all the messages that we must be going that way, and I think that's great.'

(King, M., Personal communication, August 2, 2019)

Again, Mark discusses the influencers for WellStop to develop Māori responsive policies and the importance of moving beyond tokenism, and to be authentic towards Māori, which is to integrate mātauranga Māori values and tīkanga into Te Kupenga.

Mark believes that the core to change is Māori recruitment and Māori occupying higher management roles with an emphasis on retention of Māori staff. He states;

'it's time to change, and it's time to acknowledge that Māori are good thinkers, they are good strategists, and they are strengths-based. They do know something. We are blending all the worlds together, and we are coming from that perspective. That's how this world needs to be now.'

(King, M., Personal communication, August 2, 2019)

Mark's heartfelt statements reinforce why he is the CEO as he leads from the front and expects all leaders to do the same. It is with this in mind that the Kaiārahi formed the Māori based policy, Te Kupenga.

The following section outlines all areas of influence and the filters in which the process was formed.

\subsection{WellStop's Māori Strategy: Development and implementation 2019 - 2020}

As previously discussed, the CEO and Kaiārahi Māori are the drivers of the development of WellStop's Māori policy. The following flowchart describes how WellStop will formulate their Māori policy. 


\section{Formulation of Māori based Policy|}

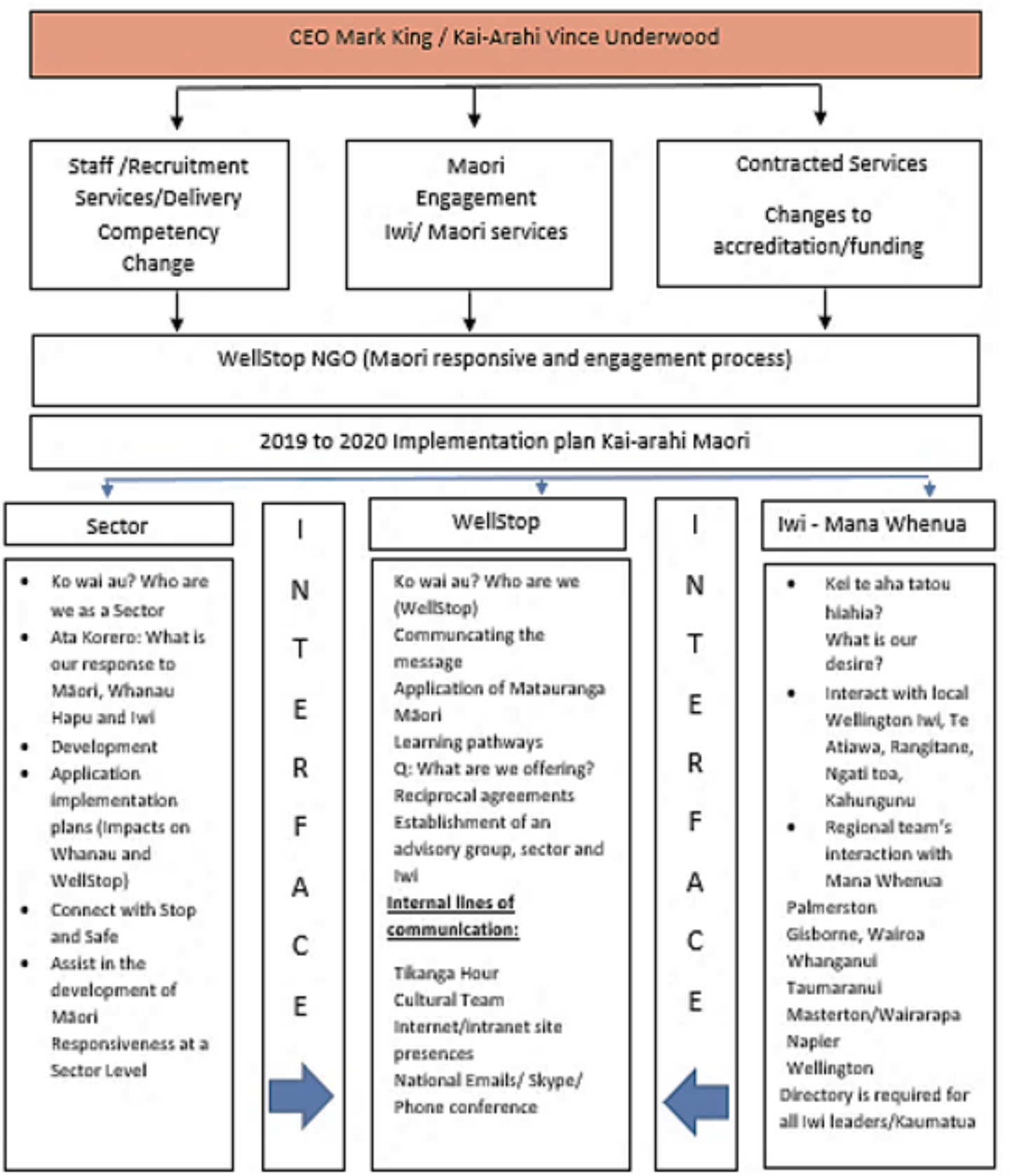

Communication currently through emails and phone, however
meetings will need to be arranged

Communication via hui with local ivil leaders

\section{PARTNERSHIP PROTECTION PARTICIPATION}

Creating opportunities for collaborative dialogue in policymaking allows for identifying solutions, is also beneficial for understanding and adapting to each other's needs, establishing valuable networks, and enabling the distribution of information among collaborators (Innes \& Booher, 2003). 
This flowchart shows the necessity of collaborating and engaging within WellStop but also with the HSB sector and iwi Mana Whenua.

The following are excerpts from The Kaiārahi Māori Progress report (Appendix H), which describes the efforts of the Kaiārahi Māori to establish WellStop's Māori responsiveness policy.

\section{Staff Engagement}

The primary goals of the Kaiārahi Māori with regards to engagement with staff is to;

'Seek ways to engage with staff

Seek ways to engage with Management

Seek ways to engage with team leaders

Training and development of Staff from a mātauranga base of training and resources'.

The Kaiārahi Māori is a member of the Senior Management Team (SMT) and provides cultural advice in all aspects of the organisation. However, WellStop is fundamentally non-Māori therefore, engagement with staff involved educating them not only in mātauranga Māori but also the value of mātauranga Māori for each of their roles through wananga about Māori arts, waiata and karakia, te reo, and Māori values and concepts and establishing repositories of knowledge and communication through intranet mediums. The Kaiārahi Māori also delivers further education and supports the clinical and social work practices of WellStop's employees by providing cultural supervision and case consultation.

Another essential piece of work has been establishing the Bicultural Group made up of one staff member from each office, both Māori and non-Māori. This allows for a cross-collaboration of voices from throughout the organisation that contributes to Te Kupenga.

\section{Engagement with the Sector}

The primary goals of the Kaiārahi Māori with regards to engagement with the Sector is to;

'Seek ways to engage with the Sector Team

Seek ways to feedback with Management

Seek ways to feedback with staff 
Offer advice on mātauranga Māori principles'.

Engaging with the Sector has involved developing the Sector Māori Responsiveness survey, analysing the data, and reporting the findings to better inform the next steps for creating the Sector Māori Responsiveness policy. In 2020, the Sector partners had not employed a senior staff member who was proficient in mātauranga Māori values and tīkanga. Therefore the Kaiārahi Māori provided Māori policy advice for the Sector. In June of 2020, the Sector partners agreed for Te Kupenga to be the Māori policy to govern a more Māori-centric operational approach across the Sector.

\section{Engagement with iwi}

The primary goals of the Kaiārahi Māori with regards to engagement with iwi is to;

'Seek ways to engage with Iwi

Seek ways to feedback with Management

Seek ways to feedback with staff'.

By utilising mātauranga Māori processes of engagement, the Kaiārahi Māori initiated contact with Ngati Toa, Te Atiawa and Rangitane, which covers all Mana-Whenua within the Wellington Region.

\subsection{Conclusion}

\section{Why has WellStop created a policy/policies that are responsive to Māori? What are the influencers?}

Four factors influence WellStop to create policies that are responsive to Māori which are;

\section{Stakeholder expectations}

More than ever, the government is devolving their service delivery and funding to NGOs such as WellStop. The development of WellStop's Māori responsive policy Te Kupenga is largely influenced by the aspirations of the current government reflected in the goals and objectives of government organisations. WellStop is a contracted provider for five government organisations, MSD, ACC, 
Corrections, $\mathrm{MOH}$ and $\mathrm{OT}$, whose goals and objectives are to improve outcomes for Māori partly through ensuring that services to Māori, and by extension the services provided by contracted providers for Māori, are culturally competent and appropriate. Therefore, to maintain their contracts with government organisations, NGOs must align with the goals and objectives of those government organisations.

\section{Social service accreditation standards and funding}

WellStop cannot function without funding. Government contracts and funding cannot be secured without meeting the accreditation criteria, including ensuring that WellStop services are culturally competent. Therefore, it is imperative for WellStop's continuation to develop Māori responsive policies that ensure the cultural competence of its services and staff. Accreditation standards compel NGOs, even those that are inherently non-Māori, to create policies that encompass the integration of mātauranga Māori and affect cultural competency. This is not an easy task for nonMāori organisations and impresses the importance of having knowledgeable, experienced Māori leadership to drive the development and implementation of these policies.

\section{Professional registration}

Social Service accreditation standards also require that WellStop employees are registered with a professional body or are working towards their professional registration. Therefore, they must meet and maintain the cultural requirements set out in those professional registration standards. WellStop is responsible for assisting their staff in meeting and maintaining those registration standards, providing opportunities for cultural supervision and access to cultural advice. It is not only imperative for WellStop's continuation to develop Māori responsive policies to ensure the cultural competence of its services and staff. The development of effective, successful, cultural, operational policies within WellStop can affect the development of theories and practises in social work (Te Momo, 2015) and also the theory and practises in psychology and counselling, which potentially results in a better understanding, open mindsets, and better outcomes for Māori.

\section{The focus of WellStop's Board and senior management}

As discussed at the beginning of this chapter, WellStop was included in this thesis because the focus of WellStop's Board and Senior Management was to develop policies that are responsive to the 
needs of Māori. It is important to note that WellStop's overarching vision is to create communities that are free from sexual harm. This vision directly influences the direction of WellStop and, by extension, influences the development of WellStop's Māori responsive policies. Mark is the driving influence behind the development of WellStop's Māori policies. It is evident in Mark's interview that his heartfelt and meaningful vision for WellStop is to embed a culture of support, caring with a professional approach within an environment led by Māori values. His passion for this vision is evident in his support of the work of the Kaiārahi Māori.

The following flowchart demonstrates how the influencers we have discussed so far filter down to WellStop and influence their development of Te Kupenga.

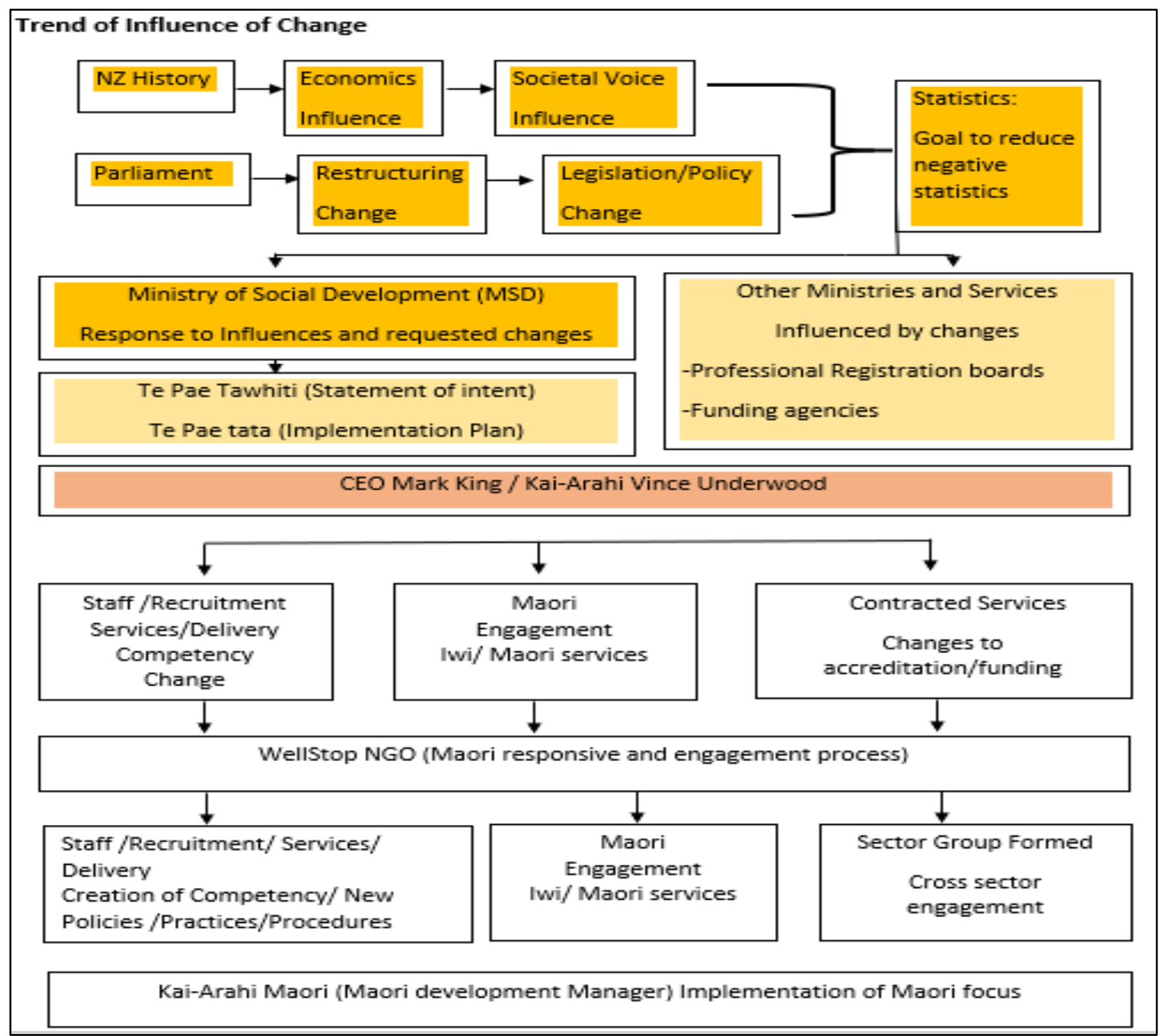

Fig:12 Factsheet: Trends of Influence of Change

(Underwood, 2019) 


\section{What steps has WellStop taken in the development of their Māori Policy and what tīkanga and mātauranga Māori did WellStop utilise in its development?}

There are several steps regarding the development of WellStop's Māori policy. While they are numbered for clarity purposes, aside from Step 1, the steps are in no particular order, and most occurred simultaneously.

\section{Leadership}

The first step in the development of WellStop's Māori Policy was initiated by the Board and CEO of WellStop to appoint a senior manager with the appropriate Māori cultural expertise to guide, direct and be a strength not just for WellStop but also for the Sector (WellStop, Stop and Safe). The responsibility of finding the appropriate person to fill that space fell to Mark, who was the Operations Manager at that time and who employed the Kaiārahi Māori. The Kaiārahi Māori has and continues to report to Mark (now CEO), who reviews and authorises each stage of the development of Te Kupenga, such as the establishment of the Bicultural Group within WellStop to drive engagement with staff and to assist in the dissemination of information with regards to Te Kupenga. The Kaiārahi Māori is also the cultural advisor to the Sector through Trinity Alliance, for which Te Kupenga is also the Māori policy.

\section{Reviewing the history}

To be able to assess the current state of WellStop's Māori organisational and operational policies, and at the request of the CEO to place a Māori worldview lens on all policies, the Kaiārahi Māori needed to review all policies to check their cultural efficacy. Also, WellStop placed importance on understanding, '... who are Māori? Where do they come from? Who are they? What's their history? Where do they fit in Aotearoa New Zealand? What is their importance?' to ascertain what would be the best direction for Te Kupenga, to create an authentic service delivery, moving beyond tokenism to address Māori needs. 


\section{Engagement and whanaungatanga with staff, iwi and sector leaders}

Engagement with staff and building strong whanaungatanga with iwi and Trinity Alliance ensures that all work together effectively to achieving the goals of cultural competency, the aspirations of WellStop's stakeholders and WellStop's overarching vision of building a world where communities are safe from sexual harm.

\section{The utilisation of mātauranga Māori and Tỉkanga}

Mark's vision for WellStop is to embed a culture of support, manakitanga and awhina with a professional approach within an environment that is led by Māori values. It has been imperative to that vision to utilise mātauranga Māori and tīkanga throughout the process of developing a Māori worldview-based policy. Those core values are set out in their whakataukī and karakia and through their five organisational values and competencies, whanaungatanga, pono, ngākaunui, manawanui and hiringa.

\section{Kaiārahi Māori Perspective}

Te Kupenga responds to the set of values adopted as core to WellStop, responds to government aspirations and the goals and objectives of government organisations that speak of working in partnership with whānau and iwi Māori to achieve better outcomes for Māori. WellStop began strategising toward being more responsive to Māori in 2019, well before the wave's crest. This placed WellStop in an advantageous position for the future, towards not being reactive but rather proactive in becoming responsive kaitiaki of whānau Māori and building an understanding of the uniqueness of whanaungatanga kinship links. It is an exciting place that WellStop is in with regards to Māori responsiveness and the continued support of staff. The engagement stage is well in hand. However, there is a growing need for networking and whanaungatanga with iwi and Māori organisations throughout the regions covered by WellStop's services. The next step is ensuring maintenance of relationships and adding value for staff education and the development of awareness and sensitivity.

The case study of WellStop has raised some interesting points. Mark's guidance has added value and mana to the ease in which the procedures have been adopted within WellStop. Although the Kaiārahi Māori role is a senior management role, it has been necessary to prove the mana and 
relevance of the role to staff and management alike. Furthermore, the establishment of the Māori responsive policy has required a delicate process as WellStop is inherently non-Māori. As such, I needed to be led by the current culture within WellStop. As discussed earlier, Cross, Bazron, Dennis, \& Isaacs (1989) define that cultural competence evolves through education. Furthermore, they describe varying degrees of cultural competency. Many of WellStop's staff were initially reluctant to adopt more than a few karakia and a handful of waiata. Therefore, the creation of Te Kupenga needed to take a back step from engagement and instead engage WellStop's staff and management in a journey towards cultural understanding and proficiency. This meant approaching sensitively by initiating small changes, the encouragement of embedding the WellStop karakia and adding voluntary lunchtime waiata practises, for example. This enabled a curiosity and enthusiasm in our staff and management to learn more. The formulation plan came into fruition only once this enthusiasm was established, which allowed for more extensive mātauranga Māori workshops educating staff of the values and principles inherent to a Māori worldview. At this stage, I was also able to speak into operational and policy-based levels of WellStop. My title allowed an open door, but it was relationships that enabled movement and acceptance.

Te Kupenga has been created and implemented as of June 2020 and is designed to evolve with changing priorities. It is not only the Māori responsive policy for WellStop but also the Sector. Like Te Pae Tawhiti and Te Pae Tata, Te Kupenga has been developed from a mātauranga Māori foundation and utilises te reo and karakia to underpin the mauri of operational policy and procedures. But like MSD, WellStop is a non-Māori organisation. Mark and I are conscious that we are governed and influenced by non-Māori stakeholders, and we are somewhat beholden to them. This does not mean we cannot act in a more Māori way. Te Kupenga responds to the set of values adopted as core to WellStop, responds to the aspirations of the government and the goals and objectives of the government organisations that we are contracted to whose policy and legislative mandates set parameters for working in partnership with whānau and iwi Māori. However, Te Kupenga is relatively new, and the data that measures the efficacy of the policy does not exist at this time. This leaves a gap for further exploration into the effectiveness of WellStop's Māori policy.

The following chapter is an osmosis of the learning from the case studies of MSD and WellStop. 


\section{Chapter 5: Conclusion: Osmosis - the accumulative learning for the formation of Māori policy}

This study sought to understand why organisations find it necessary to develop Māori responsive policies and how Māori policy is formulated and implemented in the current historical moment when the government is committed to centring Māori needs and aspirations throughout the public sector. The associated aims were to identify commonalities and best practices in the development of Māori policy and understand what Māori policymaking involves. To achieve these goals, this chapter will analyse the case studies identifying why it is necessary to develop Māori responsive policies, commonalities and best practices.

\subsection{Analysis of the case studies}

\section{The Influencers}

There are significant differences between MSD's and WellStop's influential factors in developing their Māori responsive policies. MSD has been influenced by the social, economic, statistical and government aspiration factors. These same factors indirectly influence WellStop through their stakeholder's expectations, and the standards set by Level 2 accreditation (Ministry of Social Development, 2020 (a)) and professional registration bodies (Social Workers Registration Board, n.d. (1), New Zealand Association of Counsellors - Te Roopu Kaiwhiriwhiri o Aotearoa, n.d. (3)).

The similarity between the two organisations is the influence of Hohepa and Mark's background knowledge of mātauranga Māori and their people-centric heart and drive for creating evolving policies that embed an organisational-wide Māori worldview, endorse engagement and responsiveness, and assist in the development of staff capability to work with whānau, hapū and iwi. 


\section{The incorporation of mātauranga Māori}

Te Pae Tawhiti, Te Pae Tata and Te Kupenga each have an underpinning Māori worldview-based vision. Te Pae Tawhiti and Te Pae Tata have whakataukī, while WellStop has a karakia and whakataukī. Rameka (2016) informs us that whakataukī are '...treasures from the past to support aspirations for today and the future.' Rewi (2010) discusses karakia that are dedicatory, such as WellStop's karakia, which enables people to perform their activities. It is difficult to explain the depth of meaning of karakia and whakataukī. However, they can be described as te toka tū moana, a rock standing in the ocean whereby karakia and whakataukī can stand against a wild ocean, a beacon for all. A waka without clear vision cannot see the inherent danger in not being vigilant of the rock that rests in the water. This is the importance of having clear whakatauki or karakia that lights the way and anchors the work so that all can orientate themselves and have clear sight and purpose.

Karakia and whakataukī provide a basis of belief and hope for Māori. Therefore, it is commendable that both MSD's whakataukī and WellStop's karakia are the inspirational words that are woven into the fabric of their policies. They ground the focus of their policies and policymaking in mātauranga Māori while supporting the aspirations of their organisations.

The WellStop karakia, for example, is an ideal example of hope and provides a vision of all that people can be and can receive. WellStop's whakataukī is an invitation for people to join together, to Whiria te Tangata, weave each other together to manifest a community without harm. For MSD, Unuhia Te Rito speaks of a place of hope, one where the bellbird can find rest.

'...he aha te mea nui o te ao

Māku e kī atu: he tangata, he tangata, he tangata!

... what is the greatest thing in the world? I will respond by saying: it is people, it is people, it is people!' Nā Meri Ngāroto.

(Henare P., 2016 (2))

Te Pae Tawhiti and Te Pae Tata echo this well-known whakataukī which is about people making the lives of others and their own lives better. Similarly, WellStop's whakataukī 'Whiria te Tangata' speaks of weaving people together, working together to make each other's lives better. Mark also 
eloquently spoke about changing the culture of WellStop, to create a Well-Stop where people get 'Well.' Not only the clients, whānau, hapū, iwi, but also the staff.

Hohepa and Mark are clear that embedding a Māori worldview and values across their organisations is the primary focus. Reduction of statistics is only a secondary focus. However, Hohepa and Mark believe it could be an inevitable by-product, or at least it is hoped for. The purpose, therefore, is about making life better for people, a very clear and simple purpose. They are also clear that this good work cannot be done alone. It requires good leadership and the participation of staff.

\section{The involvement of Māori in policy decision-making and leadership}

Hohepa and Mark's guidance has been valuable for their organisations. I believe, as they do, that clear guidance and appropriate leadership is needed when approaching organisational cultural change. Even more critical is embedding a culture of understanding, one which evolves and is inclusive, as depicted in Potatau Te Wherowhero's whakataukī, 'Kotahi te kohao o te ngira e kuhuna ai te miro ma, te miro pango, te miro whero. ("There is but one eye of the needle, through which the white, the black and the red threads must pass").' (Te Wherowhero, as cited in Cowan, 1955). The policies and processes adopted by MSD and WellStop illustrate a new partnership direction. Not just engagement and not just consultation, but a collaborative leadership and an open engagement process (Te Arawhiti: The Office for Māori Crown Relations, 2018 (b)) that is lead from a place of strength and understanding. For both Hohepa and Mark, they felt it was important that when including others/partners or whānau in this process, their safety and strength of voice and the adherence of their message was maintained and heard.

Furthermore, Hohepa and Mark have taken a more significant step. For MSD, Hohepa included cultural leaders and advisors, and Mark endorsed the establishment of the Kaiārahi Māori role and bicultural team. Both Mark and Hohepa have created this support as they believe that this great work should not be done in isolation. They both understand the importance of inclusive advisory and guidance panels that meet regularly to ensure the integrity of the process and respect that the mauri of the karakia and whakataukī remain forefront and prominent. 
From a place of ensuring integrity, Mark reminds management that decisions need to meet the spirit of our Karakia or 'Let's do it right the first time' or 'I would rather we don't rush'. Cost and timeframes are important but are less important to keep our eyes on the rocks in the water. Caution in these cases is not about fear of making a mistake but rather a culture of excellence.

\section{Research}

Both Hohepa and Mark found it necessary to review all previous recommendations and policies that pertain to Māori to understand the historical directions that their organisations have taken (e.g. Puao-Te-Ata-Tu and Te Punga) to develop better, more effective policies.

\section{Utilising Te Ao Māori engagement processes}

Mark and Hohepa provided the same discourse of effective engagement with Māori to understand Māori identity and their aspirations to develop policies that benefit Māori. They also felt the need to engage with other stakeholders, providers, the sector, etcetera to gain a collective view.

A key aspect of their policymaking process has been to ensure that change is supported by their staff as staff will put physical legs to the policies being formed. Mark suggests that if we invest in our staff, the likelihood is that they will drive it and, in turn, demand excellence (M. King, Personal communication, August 2, 2019). Both organisations are inherently non-Māori. Therefore their policies involve education for their staff to build enthusiasm for, and an understanding of mātauranga Māori about how mātauranga Māori benefits their practice and the importance that it holds for both Māori and non-Māori clients of their organisations. Evolving policies and processes are what is being raised by Mark and Hohepa. The outcomes of these policies are important because the value is about meeting individual care needs, the belief that if you meet their needs, then the statistics should shift overall. Although measured outcomes and cost-effective practice are a determinant, Mark and Hohepa's policies are less about establishing boxes that cubby hole or attempt to predict cause and effect, but instead focus on the people involved. If any one word is key to both policies and processes, it is 'Relationships.' He tangata, he tangata, he tangata. It is people. An evolving process needs many people with many skills. Policies and policymaking processes need people, and the solutions also need people. WellStop and MSD work to build networks with community leaders, iwi leaders and anyone else that needs to be involved. Isolation 
and silo processes may work at times. However, when dealing with clusters of traumas, the most efficient process is one that works to identify the best fit of professionals and cultural practitioners. How is this a Māori process? Māori believe and live in a space that encourages contact with others. Our pōwhiri process of engagement is an example of inclusivity and the power of Māori knowledge, of traditional values that promote bartering of skill and experience to create the best outcomes for whānau Māori and non-Māori. "Nau te rourou, naku te rourou, ka ora ai te iwi - with your food basket and my food basket, the people will be fed." (Mark, Chamberlain, \& Boulton, 2015). Yes, networking has been around for many years, and Māori do not have a monopoly on it, and yes, we don't all see eye to eye. But we know how to whanaungatanga, create kinship ties, and maintain those ties for life. I believe that Mark, Hohepa and I are best placed as we collectively understand taukumekume, the tensions that can form within relationships but also how to weave the fine strands into a beautiful work. The creation of Māori policy that can kawe (carry) many cannot be done alone. The skill of weaving different strands together is foreign to many, but as a weaver, I understand how and why each strand supports the next. I believe that it is with this understanding that Mark and Hohepa have organisations that have whakataukī about weaving.

\subsection{Final words}

Māori Policy and Crown relationships have historically shifted, from imposed measures (Rakena, 1961), assimilation and integration (Swain, 1987), to management (Derby, 2013), consultation (Mahuika, 2015), devolution of powers and resources (Belgrave, 2014; Hill, 2009, p. 237), and now genuine engagement and partnership within a Te Ao Māori context (Te Arawhiti: The Office for Māori Crown Relations, 2018 (b)). Such a shift in government intentions directly influences government organisations and, through capability measures, influences NGOs to develop policies that are responsive to the aspirations and capability of Māori.

Maaka \& Fleras (2009) suggest that policymaking should recognise the distinctive Māori view of the world, respect indigenous difference by incorporating that view into policymaking, and acknowledge that Māori alone possess the right to decide for themselves what is best. To evaluate what would be most beneficial for Māori and establish what aspirations and capabilities Māori have, 
organisations must engage with Māori. Unfortunately, ongoing tokenism and lack of implementation (Hollis-English A. N., 2012 (a)) have perpetuated a mindset of scepticism (Smith L. T., Decolonizing Methodologies: Research and Indigenous Peoples, 2006 (a), p. 107), bitterness and doubt (Tolich, 2002), and consultation fatigue (Clarke, 2015) among Māori. Therefore, for engagement to be meaningful and successful, organisations must first traverse the difficult journey of building trust to counter the negative sentiments and cynicism of Māori. Furthermore, a lack of representation of Māori within policy decision-making (Bargh, 2016) creates an imbalance of power that can result in the loss of confidence in the process (Clarke, 2015). Most people have an inkling of what authentic (as opposed to tokenistic) policies might be, but specific measures of authenticity are yet to be defined. The Māori policy arena is currently on the precipice of change. As such, the current context of Māori policy cannot be defined by past precedents because they don't exist. What then defines authentically Māori (as opposed to tokenistic) policy? Is it determined by the amount of mātauranga Māori content or the understanding of and intent behind the inclusion of mātauranga Māori? This thesis suggests that authenticity can be achieved through the guidance of Māori leaders who obtain mātauranga Māori expertise, by utilising mātauranga Māori based processes of engagement and ensuring the efficacious transfer of Māori feedback into the final policies and the implementation of those policies. Equally, to ensure the policy is authentic, it must also be grounded in mātauranga Māori from the outset.

Te Arawhiti's frameworks for Māori Crown capability encourage not just engagement with Māori but partnering with Māori, including Māori in every stage of policymaking and affording Māori the right to make decisions about their future (Te Arawhiti - The Office for Māori Crown Relations, 2019; 2019 (a)). With the support of these Crown instigated frameworks, there is every hope that Māori responsive policies will live up to the expectations of Māori.

MSD and WellStop are non-Māori entities that aim to embed a Māori worldview into the fabric of their organisations. They also provide social services to more than just Māori and therefore must consider the impact that policy could have for all. Ringold (2005) agrees that in New Zealand, Māori are significant, and the contribution from Māori is vast. However, she discusses that New Zealand policy is largely designed around the 'Majority' and not the 'Minority' regardless of contribution. Furthermore, she argues that New Zealand policy has sought to include Māori within the development of strategy but questions whether Māori focussed programmes and mainstream 
programmes are clear cut as Māori appear to participate in both. Mātauranga Māori is not static but has the creative potential to evolve with the contexts in which it is used (Royal T. A., 2005). Here, I'd like to note that Māori tīkanga, kawa, mātauranga and values originate from a communal culture (Houkamau \& Sibley, 2019) that is '...constituted on values of relationality, collectivism, reciprocity and connectivity...' (Hook, Waaka, \& Raumati, 2007). As such, the innovative use of mātauranga Māori in policymaking has the potential to benefit all, which validates the current climate of creating Māori policy that benefits all and not just Māori. Where Broughton \& McBreen (2015) explain that for the past 100 years, Māori mātauranga has been marginalised, what MSD and WellStop aim to achieve would dispel the notion of marginalisation.

\subsection{Further research}

I have discussed the question 'What is Māori Policy?' While I make some conclusions with regards to Māori policy, the scope of my research is limited to just one government organisation and one NGO. MSD and WellStop are not the only organisations who are developing Māori responsive policy. My discussions in chapter 4 show that many government organisations are creating Māori responsive policies. Likely, many other NGOs are looking to establish Māori responsive policies. As such, a more extensive cross-section, comprehensive study and research would be beneficial to build a picture of the Māori Policy landscape.

The scope of this study did not delve into the policies that iwi and kaupapa Māori social services organisations are developing to cope with the increase of devolution of government services to Iwi. As such, the social policy landscape could also benefit from a more extensive study of the development of Māori responsive policies within government, non-government and iwi and kaupapa Māori social service organisations.

I have discussed tokenism and the strong sense of cynicism among Māori that must be countered before the type of meaningful engagement mentioned by Te Arawhiti can happen. This study has identified some valuable insights into the benefits of utilising mātauranga Māori and tīkanga during the engagement process. Again, this is only from the perspective of a limited scope. With regards to 
engagement with Māori through advisory groups, Came, McCreanor, Haenga-Collins \& Comes' (2019) qualitative study into the experiences of Māori and Pasifika leaders as participants in government health advisory groups showed that participants in the study felt that despite their extensive experience in the health system, their knowledge and interests were undervalued, and their experiences encompassed racism and tokenistic engagement. This clearly shows disparities in practices of engagement with Māori. The social policy landscape could find value in a more extensive study into the types of engagement with Māori that exist to identify disparities and how to counter a deeply embedded cynicism among Māori to achieve meaningful engagement.

Related to this is what defines authentically Māori (as opposed to tokenistic) policy? Is it determined by the amount of mātauranga Māori content or the understanding of and intent behind the inclusion of mātauranga Māori? While this question is somewhat answered within this study, a more comprehensive study into what is deemed authentically Māori policy could aid future Māori responsive policymakers.

I have spoken of the cultural competency measures that NGOs must achieve to obtain and maintain their funding sources and how they influence Mãori policymaking. External to the scope of this thesis is an examination of the development of those measures and whether they too have had significant input from Māori. The policy arena could also benefit from examining the development of these measures, which have such a noticeable effect on Māori policymaking. 


\section{Bibliography}

Anaru, N. A. (2011, Nov). A critical analysis of the impact of colonisation on the Māori language through an examination of political theory. [MA Thesis, Auckland University of Technology].

Aotearoa New Zealand Association of Social Workers. (n.d. (c)). Te Tiriti o Waitangi / The Treaty of Waitangi. Retrieved December 15, 2019, from https://anzasw.nz/te-tiriti-o-waitangi-thetreaty-of-waitangi/

Awatere, S., \& Harmsworth, G. (2014). Ngā Aroturukitanga tika mō ngō Kaitiaki: Summary review of mātauranga Māori frameworks, approaches, and culturally appropriate monitoring tools for management of mahinga kai. University of Waikato. Retrieved Apr 10, 2021, from https://www.waikatoregion.govt.nz/assets/PageFiles/29535/Maori\%20frameworks\%20ap proaches\%20and\%20culturally\%20appropriate\%20monitoring\%20tools\%20for\%20manage ment\%20of\%20mahinga\%20kai.pdf

Banks, J. A. (1998). The lives and values of researcher: Implications for educating citizens in a multicultural society. Educational Researcher, 27(7), 4-17.

Bargh, M. (2016). Opportunities and complexities for Māori and mana whenua representation in local government. Political Science, 68(2), 143-160. doi:https://doi.org/10.1177/0032318716671765

Barrett, M., \& Connolly-Stone, K. (1998). The Treaty of Waitangi and social policy. The Social Policy Journal of New Zealand - Te Puna Whakaaro(11), 29-47.

Bawden, J. (2008). Governance in not for profit organisations in New Zealand. [MA Dissertation, University of Auckalnd].

Beddoe, L., \& Duke, J. (2009). Registration in New Zealand social work. International Social Work, 52(6), 785-797. doi:10.1177/0020872809342649

Belgrave, M. (2014). Beyond the Treaty of Waitangi: Māori tribal aspirations in an era of reform, 1984-2014. The Journal of Pacific History, 49(2), 193-213.

doi:10.1080/00223344.2014.898232

Best, E. (1924). The Maori: Volume 1 (Vol. Part of: The Published Works of Elsdon Best).

Wellington, New Zealand: The Board of Maori Ethnological Research. Retrieved Jan 27, 2020, from http://nzetc.victoria.ac.nz/tm/scholarly/tei-Bes01Maor-t1-body-d7.html Bhandari, P. (2020, Jun 119). An introduction to qualitative research. Retrieved Feb 8, 2021, from Scribbr: https://www.scribbr.com/methodology/qualitative- 
research/\#: :text=APA\%20Citation\%20Generator-

,An\%20introduction\%20to\%20qualitative\%20research,19\%2C\%202020\%20by\%20Pritha\%2 OBhandari.\&text=Qualitative\%20research\%20involves\%20collecting\%20and,concepts\%2C $\% 20$ op

Bishop, R. (2005). Te Kotahitanga: Kaupapa Maori Research in Action. Presentation to PRIDE project workshop on Teacher Education. Apia, Samoa.

Borell, B., Barnes, H. M., \& McCreanor, T. (2017). Conceptualising historical privilege: the flip side of historical trauma, a brief examination. AlterNative: An International Journal of Indigenous Peoples, 14(1), 25-34. doi:https://doi.org/10.1177/1177180117742202

Boulton, A., Levy, M., \& Cvitanovic, L. (2020, Dec). Beyond Puao-Te-Ata-Tu: Realising the promise of a new day. Retrieved Apr 3, 2021, from Ngā Pae o te Māramatanga: http://www.maramatanga.ac.nz/sites/default/files/teArotahi_20-1106.pdf

Brannick, T., \& Coghlan, D. (2007). In Defense of Being "Native": The Case for Insider Academic Research. Organizational Research Methods, 10(1), 59-74.

Brougham, A. E., \& Reed, A. W. (2012). Te Raupō book of Māori proverbs (ebook ed.). (T. Kāretu, Ed.) New Zealand: Penguin Random House.

Broughton, D., \& McBreen, K. (2015). Mātauranga Māori, tino rangatiratanga and the future of New Zealand Science. Journal of the Royal Society of New Zealand, 45(2), 83-88. doi:10.1080/03036758.2015.1011171

Calman, R. (2012, Jun 20). Māori education - mātauranga - Kaupapa Māori education. Retrieved Oct 2019, 2019, from Te Ara - the Encyclopedia of New Zealand: https://teara.govt.nz/en/maori-education-matauranga/page-5

Came, H. A. (2012). Institutional racism and the dynamics of privilege in public health. [Doctoral Thesis, The University of Waikato]. Retrieved March 7, 2021, from https://researchcommons.waikato.ac.nz/handle/10289/6397

Came, H., McCreanor, T., Haenga-Collins, M., \& Cornes, R. (2019). Māori and Pasifika leaders' experiences of government health advisory groups in New Zealand. Kōtuitui: New Zealand Journal of Social Sciences Online, 14(1), 126-135. doi:https://doi.org/10.1080/1177083X.2018.1561477

Came, H., O'Sullivan, D., \& McCreanor, T. (2020). Introducing critical Tiriti policy analysis through a retrospective review of the New Zealand Primary Health Care Strategy. Ethnicities. doi:https://doi.org/10.1177/1468796819896466 
Cavino, H. M. (2016). Intergenerational sexual violence and whānau in Aotearoa/New Zealand Pedagogies of Contextualisation and Transformation. Sexual Abuse in Australia and New Zealand, 7(1), 4-17.

Chamberlin, J. E. (2004). If this is your land, where are your stories? Toronto: Vintage Canada.

Chergui, W., Zidat, S., \& Marir, F. (2020). An approach to the acquisition of tacit knowledge based on an ontological model. Journal of King Saud University - computer and information sciences, 32(7), 818-828. doi:https://doi.org/10.1016/j.jksuci.2018.09.012

Ciucescu, N. (2009). The role and importance of Non-Profit Organizations. Studies and scientific researches, economics edition, no. 14, 14-19.

Clarke, J. (2015). Māori Participation and Representation: An Investigation into Māori reported experiences of Participation and Representation within the policy process post-MMP. Masters Thesis, University of Canterbury. Retrieved Jan 23, 2021, from https://ir.canterbury.ac.nz/bitstream/handle/10092/11338/JosephineClarkeMA.pdf?seque nce $=1$

Consedine, B. (2007). Historical influences: Māori and the economy. Te Puni Kōkiri. Retrieved Feb 14, 2021, from https://www.tpk.govt.nz/documents/download/102/tpk-histoicinfluence2007-eng.pdf

Cowan, J. (1955). The New Zealand wars: A history of the Māori campaigns and the pioneering period: Volume I: 1845-1864. Wellington: R. E. Owen. Retrieved Nov 7, 2020, from http://nzetc.victoria.ac.nz/tm/scholarly/tei-Cow01NewZ-b1-1-9.html

Cram, F. (2001). Rangahau Māori: Tona tika, tona pono. In M. Tolich (Ed.), Research ethics in Aotearoa (pp. 35-52). Auckland: Longman.

Cram, F. (2009). Maintaining indigenous voices. In D. Mertens, \& P. Ginsberg (Eds.), SAGE Handbook of social science research ethics (pp. 308-322). California: Sage.

Cross, T. L., Bazron, B. J., Dennis, K. W., \& Isaacs, M. R. (1989). Towards a culturally competent system of care: A monograph on effective services for minority children who Are severely emotionally disturbed. Washington DC: Georgetown University. Child Development Center. Retrieved Mar 14, 2021, from https://files.eric.ed.gov/fulltext/ED330171.pdf

Dale, M., Mooney, H., \& O'Donohue, K. (2017). Defining social work in aotearoa. Auckland: Massey University Press.

Dalley, B. (2018, Apr 11). Child abuse - High-profile child-abuse cases. Retrieved Oct 30, 2019, from Te Ara - the Encyclopedia of New Zealand: https://teara.govt.nz/en/child-abuse/page-2 
Dalley, B. (2018, Apr 11). Child abuse - State action on child abuse. Retrieved Oct 30, 2019, from Te Ara - the Encyclopedia of New Zealand: https://teara.govt.nz/en/child-abuse/page-3

Denzin, N. K., \& Lincoln, Y. S. (2005). Introduction. The discipline and practice of qualitative research. In The Sage handbook of qualitative research, ed (pp. 1-32). Thousand Oaks: SAGE Publications.

Department of Corrections. (2019, Mar). Prison facts and statistics - March 2019. Retrieved Nov 9 , 2019, from Department of Corrections:

https://www.corrections.govt.nz/resources/research_and_statistics/quarterly_prison_stati stics/prison_stats_march_2019\#ethnicity

Department of Social Welfare. (1988, Sep). Puao-Te-Ata-Tu. Retrieved Apr 3, 2018, from Ministry of Social Development: https://www.msd.govt.nz/documents/about-msd-and-ourwork/publications-resources/archive/1988-puaoteatatu.pdf

Derby, M. (2013, September 5). Origin of the hongi. Retrieved November 9, 2019, from Te Ara the Encyclopedia of New Zealand: https://teara.govt.nz/en/artwork/41176/origin-of-thehongi

Dobbs, T. (2015). Te Ao Kohatu. Wellington: Ministry of Social development. Retrieved Feb 20, 2019, from https://practice.orangatamariki.govt.nz/assets/documents/policy/workingwith-m-ori/literature-review-dobbs-2015.pdf

Dociu, M., \& Dunarintu, A. (2012). The socio-economic impact of urbanization. International Journal of Academic Research in Accounting, Finance and Management Services, Vol 2(Special Issue1), 47-52.

Duff, M. (2012, May 06). The mother of kohanga reo. Retrieved Jan 14, 2020, from stuff.co.nz: http://www.stuff.co.nz/dominion-post/capital-life/6865335/The-mother-of-kohanga-reo

Durie, M. (2003). The health of indigenous peoples. BMJ (Online), 326, 510-511. doi:10.1136/bmj.326.7388.510

Durie, M. H. (1985). A Maori perspective of health. Social Science and Medicine, 483-486.

Durie, M., Cooper, R., Grennell, D., Snively, S., \& Tuaine, N. (2010). Whānau Ora: Report of the Taskforce on Whānau-Centred Initiatives. Wellington: The Department of Internal Affairs.

Dwyer, S. C., \& Buckle, J. L. (2009). The space between: On being an insider-outsider in qualitative research. International Journal of Qualitative Methods, 8(1), 54-63. doi:https://doi.org/10.1177/160940690900800105 
E Tu Whānau. (n.d.). MRG Members. Retrieved Jun 15, 2019, from E Tū Whānau; Te Mana Kaha o te Whānau: http://etuwhanau.org.nz/about/the-people/maori-reference-group/

Farrelly, S., Rudegeaire, T., \& Rickard, S. (2006). Trauma and dissociation in aotearoa (New Zealand): The psyche of a society. Journal of Trauma Practice, 4(3-4), 203-220. doi:https://doi.org/10.1300/J189v04n03_02

Freeman, R. E., \& Mcvea, J. F. (2001). A stakeholder approach to strategic management. (Working Paper No. 01-02). University of Virginia. doi:10.2139/ssrn.263511

Hackell, M. A. (2007). Towards a neoliberal citizenship regime: A post-Marxist discourse analysis. In [Thesis, Doctor of Philosophy (PHD)]. Hamilton, New Zealand: University of Waikato. Retrieved Feb 20, 2021, from https://hdl.handle.net/10289/2530

Haddon, C., Devanny, J., Forsdick, C., \& Thompson, A. (2015). What is the value of history in policymaking? Arts and Humanities Research Council. Retrieved Apr 2021, 11, from instituteforgovernment.org.uk/sites/default/files/publications/Making\%20History\%20Wor k\%20Report\%20-\%20Final_0.pdf

Hayward, J. (2012 (a), Jun 20). Biculturalism. Retrieved Oct 30, 2019, from Te Ara - the Encyclopedia of New Zealand: https://teara.govt.nz/en/biculturalism/print Hayward, J. (2012 (b), Jun 20). Principles of the Treaty of Waitangi: Ngā mātāpono o Te Tiriti Treaty principles developed by courts. Retrieved Oct 30, 2019, from Te Ara - the Encyclopedia of New Zealand: https://teara.govt.nz/en/principles-of-the-treaty-ofwaitangi-nga-matapono-o-te-tiriti/page-2

Henare, P. (2016 (a), Nov 29). Children, Young Persons, and Their Families (Advocacy, Workforce, and Age Settings) Amendment Bill - Third Reading. Retrieved Jan 5, 2020, from New Zealand Parliament: https://www.parliament.nz/en/pb/hansarddebates/rhr/document/HansS_20161129_078300000/henare-peeni

Henare, P. (2016 (b), Nov 29). Hansard (Debates). Retrieved Jun 7, 2020, from New Zealand Parliament: https://www.parliament.nz/en/pb/hansarddebates/rhr/document/HansS_20161129_078300000/henare-peeni

Henare, T. (1998, Jul 14). Progress towards closing social and economic gaps between Māori and non-Maori. Retrieved Feb 8, 2020, from The official website of the New Zealand Government: https://www.beehive.govt.nz/release/progress-towards-closing-social-andeconomic-gaps-between-maori-and-non-maori 
Hetaraka, M. (2019). A kaupapa Māori analysis of Tātaiako. Mai Journal, 8(2), 159-171. doi:10.20507/MAIJournal.2019.8.2.5

Hikuroa, D. (2017). Mātauranga Māori: The ūkaipō of knowledge in New Zealand. Journal of the Royal Society of New Zealand, 47:1, 5-10. doi:https://doi.org/10.1080/03036758.2016.1252407

Hill, R. (2009). Maori and the State: Crown-Māori relations in New Zealand/Aotearoa, 1950-2000. Wellington: Victoria University Press.

Hill, R. S. (2010). Fitting multiculturalism into biculturalism: Māori-pasifika relations in New Zealand from the 1960s. Ethnohistory, 57(2), 291-319. doi:https://doi.org/10.1215/00141801-2009-064

Hollis-English, A. (2012 (b)). Pūao-te-Āta-tū: Informing Māori social work since 1986. Atearoa New Zealand Social Work, 24 (3\&4), 41-48. doi:10.11157/anzswj-vol24iss3-4id123 Hollis-English, A. N. (2012 (a)). Māori social workers: Experiences within social service organisations. [Doctoral Thesis, University of Otago].

Hook, G., Waaka, T., \& Raumati, L. (2007). The multi-dimensional model of Māori identity and cultural engagement. New Zealand Journal of Psychology, 39(1), 8-28.

Houkamau, C. A., \& Sibley, C. G. (2019). The role of culture and identity for economic values: a quantitative study of Māori attitudes. Journal of the Royal Society of New Zealand, 49(S1), 118-136. doi:https://doi.org/10.1080/03036758.2019.1650782

Humpage, L. V. (2002). Closing the gaps? The politics of Māori Affairs policy. Auckland: Massey University.

Humpage, L., \& Fleras, A. (2001). Intersecting discourses: Closing the gaps, social justice and the Treaty of Waitangi. Social Policy Journal of New Zealand(16), 37-53.

Hunn, J. K. (1961). Report on department of Māori affairs: with statistical supplement. Wellington: Government Printer.

Hunt, S. (2017). The social work regulation project in Aotearoa New Zealand. Aotearoa New Zealand Social Work, 29(1), 53-64. doi:https://doi.org/10.11157/anzswj-vol29iss1id370 Innes, J. E., \& Booher, D. E. (2003). Collaborative policy making: governance through dialogue. In M. W. Hajer, \& H. Wagenaar (Eds.), Deliberative Policy Analysis: Governance in the Network Society (pp. 33-59). Cambridge: Cambridge University Press. 
Janssen, T., \& Forbes, S. (2014). The use of official statistics in evidence based policy making in New Zealand. Wellington: Statistics New Zealand. Retrieved Apr 4, 2021, from https://icots.info/9/proceedings/pdfs/ICOTS9_5A1_FORBES.pdf Jina, R., \& Thomas, L. S. (2013). Health consequences of sexual violence against women. Best Parctice \& Research Clinical Obstetrics \& Gynaecology, 27(1), 15-26. doi:https://doi.org/10.1016/j.bpobgyn.2012.08.012

Justice, D. H. (2018). Why indigenous literatures matter (EPUB ed.). Wilfrid Laurier University Press.

Kapiti Coast District Council. (n.d.). Valuing language, culture and identity. Retrieved Apr 11, 2021, from Kapiti Coast District Council: https://www.kapiticoast.govt.nz/libraries/heritagemaori/maori/te-reo/whakatauki/

Keane, B. (2012 (a), Jun 20). Story: Kotahitanga - unity movements. Retrieved Feb 14, 2021, from Te Ara - the Encyclopedia of New Zealand: https://teara.govt.nz/en/photograph/33600/hikoi-to-waitangi

Keane, B. (2012 (b), Jun 20). Ngā rōpū tautohetohe: Māori protest movements - Waitangi Day protests. Retrieved Aug 17, 2019, from Te Ara - the Encyclopedia of New Zealand: https://teara.govt.nz/en/nga-ropu-tautohetohe-maori-protest-movements/page-2

Kendell, E. (2007). Cultural Identity and the Children, Young Persons, and Their Families Act 1989: Ideology, Policy and Practice. Social Policy Journal of New Zealand: Te Puna Whakaaro(ISS 32), 49-71. Retrieved from Ministry of Social Development:

https://www.msd.govt.nz/about-msd-and-our-work/publications-resources/journals-andmagazines/social-policy-journal/spj32/32-cultural-identity-and-the-children-youngpersons-and-their-families-act-1989-pages49-71.html

Kikumura, A. (1998). Family life histories: A collaborative venture. In R. Perks, \& A. Thomson (Eds.), The oral history reader (pp. 140-144). London: Routledge.

King, M. (2019, Aug 2). WellStop Chief Executive Officer. (V. Underwood, Interviewer)

Kiro, C. A. (2001). Kimihia Hauora Māori: Māori health policy and practice. [Doctoral Thesis]. Albany, Auckland: Massey University.

Labour Party. (2020 (a)). Labour. Retrieved Jan 15, 2021, from Labour: https://www.labour.org.nz/maori

Labour Party. (2020 (b), Sept 26). Labour Māori manifesto 2020. Retrieved Mar 3, 2021, from Labour.org.nz: https://www.labour.org.nz/maori-manifesto 
Larner, W. (2002). Neoliberalism and tino rangatiratanga: Welfare state restructuring in Aotearoa/New Zealand. In C. Kingfisher (Ed.), Western Welfare in Decline: Globalization and Women's Poverty (pp. 151-152). University of Pennsylvania Press. Retrieved from http://www.jstor.org/stable/j.ctt3fhwvt.11

Levy, M. (1999). Policy for Maori: values, assumptions and closing the gap. In N. Robertson (Ed.), Maori and psychology: research and practice - The proceedings of a symposium sponsored by the Maori and Psychology Research Unit. Hamilton: Maori \& Psychology Research Unit, University of Waikato.

Lowry, A., \& Simon-Kumar, R. (2017). The paradoxes of Māori-state inclusion: the case study of the Ōhiwa harbour strategy. Political Science, 69(3), 195-213.

Lundy, L. (2018). In defence of tokenism? Implementing children's right to participate in collective decision-making. Childhood, 25(3), 340-354. doi:10.1177/0907568218777292

Luxton, H. (1996, Oct 1). Maori policy initiatives. Retrieved Feb 25, 2019, from Beehive.govt.nz: https://www.beehive.govt.nz/feature/maori-policy-initiatives

Maaka, R. C. (2003). Perceptions, conceptions and realities: a study of the tribe in Maori society in the twentieth century. [Doctoral Thesis, University of Canterbury, Christchurch, New Zealand].

Maaka, R., \& Fleras, A. (2009). Mainstreaming indigeneity by indigenizing policymaking: Towards an Indigenous grounded analysis framework as policy paradigm. Indigenous Policy Journal, Vol XX(No. 3).

Mahuika, N. (2015). New Zealand history is Maori history: Tikanga as the ethical foundation of historical scholarship in Aotearoa New Zealand. New Zealand Journal of History, 49(1), 530.

Manch, T. (2019, Mar 15). More than 220 children abused in Oranga Tamariki care in 2018. Retrieved Oct 30, 2019, from Stuff.co.nz: https://www.stuff.co.nz/national/111266757/more-than-220-children-abused-in-orangatamariki-care-in-2018

Mark, G., Chamberlain, K., \& Boulton, A. (2015). Rourou Māori methodological approach to research. Mai Journal, 4(1), 60-70. Retrieved Apr 26, 2021, from http://www.journal.mai.ac.nz/sites/default/files/MAlJrnl_V4Iss1_Mark.pdf

Marriott, L., \& Sim, D. (2014). Indicators for inequality for Māori and Pacific people. [Working paper 09/2014]. Wellington, New Zealand: Victoria University of Wellington. 
Martin, Jenkins \& Associates Ltd. (2020). Indicative estimates of the size of cohorts and levels of abuse in state and faith-based care - 1950 to 2019. Wellington: Martin, Jenkins \& Associates Ltd.

McCreanor, T. (1993). Settling grievances to deny sovereignty: Trade goods for the year 2000. Sites: A Journal for South Pacific Cultural Studies, 27 (Summer), 45-73.

McGrath, C., Palmgren, P., \& Leljedahl, M. (2019). Twelve tips for conducting qualitative research. Medical Teacher, 41(9), 1002-1006. doi:10.1080/0142159X.2018.1497149

McLean, C., Long, M. A., Stretesky, P. B., Lynch, M. J., \& Hall , S. (2019). Exploring the relationship between neoliberalism and homicide: A cross-national perspective. International Joural of Sociology, 49(1), 53-76. doi:https://doi.org/10.1080/00207659.2018.1560981

Mead, H. M. (2016). Tikanga Māori: Living by Māori values (Revised ed.). Huia Publishers.

Mead, H. M. (2016). Tikanga Māori: Living by Māori values (Revised Edition) (ebook ed.). Huia Publishers.

Mead, H. M., Adds, P., Gray, E., Hetaraka, W., Harris, D., Takarangi, M., \& White, G. (2003). Māori experiences of the direct negotiation process: Case studies and personal experiences of various negotiators on the negotiation process with the Crown to settle claims under the Treaty of Waitangi. Wellington: Crown Forestry Rental Trust. Retrieved Oct 30, 2019, from https://cfrt.org.nz/wp/wp-content/uploads/2018/05/experiences.pdf

Medallist, B. (2018). Dame Tariana Turia. Retrieved Feb 14, 2021, from Blakenz.org: https://www.blakenz.org/person/dame-tariana-turia/

Meredith, P. (2005, Feb 8). Urban Māori - Urbanisation. Retrieved Aug 17, 2019, from Te Ara Encyclopedia: https://teara.govt.nz/en/urban-maori/page-1

Metge, J., \& Jones, S. (1995, Jul). He taonga tuku iho nō ngā tūpuna: Māori proverbial sayings - a literary treasure. New Zealand Studies, 5(2), 3-7.

Ministry for Culture and Heritage. (2017 (a), Jul 25). Bastion Point land returned. Retrieved Aug 17, 2019, from New Zealand History: https://nzhistory.govt.nz/the-government-announcesreturn-of-bastion-point-to-maori-owners

MInistry for Culture and Heritage. (2017 (b), May 17). Jack Hunn biography. Retrieved October 20, 2019, from Ministry for Culture and Heretage: https://nzhistory.govt.nz/people/jack-kenthunn 
Ministry for Culture and Heritage. (2018 (a), May 9). The 1970s Page 6 - 1973 - key events.

Retrieved August 17, 2019, from New Zealand History:

https://nzhistory.govt.nz/culture/the-1970s/1973

Ministry for Culture and Heritage. (2018 (b), Mar 13). Whina Cooper leads land march to

Parliament. Retrieved Aug 17, 2019, from New Zealand History:

https://nzhistory.govt.nz/whina-cooper-led-land-march-te-ropu-o-te-matakite-reachesparliament

Ministry for Culture and Heritage. (2019 (a), Apr 8). Hōne Heke. Retrieved Oct 20, 2019, from

Ministry for Culture and Heritage: https://nzhistory.govt.nz/people/hone-heke

Ministry for Culture and Heritage. (2019 (b), Aug 26). Treaty events since 1950. Retrieved from

Ministry for Culture and Heritage: https://nzhistory.govt.nz/politics/treaty/treaty-

timeline/treaty-events-1950

Ministry of Business, Innovation and Employment. (2019). Māori in the labour market - June 2019

Year. Retrieved Nov 1, 2019, from Ministry of Business, Innovation and Employment:

https://www.mbie.govt.nz/assets/maori-labour-market-trends-june-2019.pdf

Ministry of Education. (2007). 2007 New Zealand schools: Ngā kura o Aotearoa (2007). Retrieved

November 9, 2019, from Education Counts:

https://www.educationcounts.govt.nz/publications/series/2523/31929/3

Ministry of Health. (2017). Statement of Strategic Intentions 2017 to 2021. Retrieved Mar 14,

2021, from Ministry of Health:

https://www.health.govt.nz/system/files/documents/publications/statement-of-strategicintentions-2017-to-2021-ministry-of-health.pdf

Ministry of Social Development - Te Manatū Whakahiato Ora. (2018 (c), July). Statement of Intent 2018-2022. Retrieved February 19, 2019, from Ministry of Social Development - Te Manatū Whakahiato Ora: https://www.msd.govt.nz/about-msd-and-our-work/publicationsresources/corporate/statement-of-intent/index.html

Ministry of Social Development. (2016 (a), Jul 29). Official information responses 29 JUL 2016.

Retrieved Aug 15, 2019, from Ministry of Social Development:

https://www.msd.govt.nz/documents/about-msd-and-our-work/publicationsresources/official-information-responses/2016/july/20160729-benefit-statistics.pdf

Ministry of Social Development. (2016 (b)). The Social Report 2016 - Te pürongo oranga tangata.

Ministry of Social Development - Te Manatū Whakahiato Ora. Ministry of Social 
Development. Retrieved from http://socialreport.msd.govt.nz/paid-

work/unemployment.html\#ethnic-differences

Ministry of Social Development. (2017, September). Statement of Intent 2017-2022. Retrieved

December 15, 2019, from Ministry of Social Development:

https://www.msd.govt.nz/documents/about-msd-and-our-work/publications-

resources/corporate/statement-of-intent/2017/soi-2017-2022.pdf

Ministry of Social Development. (2018 (a), Jun). 2018 Benefit fact sheets archive. Retrieved Jun 30, 2019, from Ministry of Social Development: https://www.msd.govt.nz/about-msd-and-ourwork/publications-resources/statistics/benefit/archive-2018.html

Ministry of Social Development. (2018 (b)). Pūrongo ā-tau - annual report 2017/2018. Ministry of

Social Development. Wellington: Ministry of Social Development. Retrieved November 9, 2019, from Ministry of Social Development: https://www.msd.govt.nz/documents/aboutmsd-and-our-work/publications-resources/corporate/annual-report/2018/pages-fromannual-report-vol-1.pdf

Ministry of Social Development. (2018 (c), Jul). Statement of Intent 2018-2022. Retrieved Feb 19, 2019, from Ministry of Social Development: https://www.msd.govt.nz/about-msd-and-ourwork/publications-resources/corporate/statement-of-intent/index.html

Ministry of Social Development. (2018 (d)). Tauākī Whakamaunga Atu: Statement of Intent 20182022. Wellington: Ministry of Social Development.

Ministry of Social Development. (2019 (a), Jan). Our strategy - our voice (providers). Retrieved November 9, 2019, from Ministry of Social Development: https://www.msd.govt.nz/documents/about-msd-and-our-work/newsroom/te-pae-tatathe-strategy-3-providers.pdf

Ministry of Social Development. (2019 (b), Jan). Our strategy - our voice (staff). Retrieved November 9, 2019, from Ministry of Social Development: https://www.msd.govt.nz/documents/about-msd-and-our-work/newsroom/te-pae-tatathe-strategy-3-staff.pdf

Ministry of Social Development. (2019 (c), Jan). Our strategy - our voice (whānau). Retrieved November 9, 2019, from Ministry of Social Development: https://www.msd.govt.nz/documents/about-msd-and-our-work/newsroom/te-pae-tatathe-strategy-3-whanau.pdf 
Ministry of Social Development. (2019 (d), Ministry of Social Development). Pūrongo ā-tau annual report 2018/2019. Retrieved Jan 8, 2020, from https://www.msd.govt.nz/documents/about-msd-and-our-work/publicationsresources/corporate/annual-report/2019/annual-report-2018-19.pdf

Ministry of Social Development. (2019 (f), Jan). Te Pae Tata - the strategy. Retrieved November 9, 2019, from Ministry of Social Development: https://www.msd.govt.nz/documents/aboutmsd-and-our-work/newsroom/te-pae-tata-the-strategy-3-strategy.pdf

Ministry of Social Development. (2019 (g)). Te Pae Tata Māori strategy and action plan. Retrieved Feb 20, 2019, from Ministry of Social Development:

https://www.msd.govt.nz/documents/about-msd-and-our-work/about-msd/strategies/tepae-tata/te-pae-tata-maori-strategy-and-action-plan-booklet.pdf

Ministry of Social Development. (2020 (a), Nov). Accreditation standards. Retrieved November 17, 2019, from Ministry of Social Development: https://www.msd.govt.nz/what-we-cando/providers/social-services-accreditation/accreditation-standards.html

Ministry of Social Development. (2020 (b), Nov). Accreditation standards. Retrieved November 17, 2019, from Ministry of Social Development: https://www.msd.govt.nz/what-we-cando/providers/social-services-accreditation/accreditation-standards.html

Ministry of Social Development. (2020 (c)). Pūrongo ā-tau - annual report 2019/2020. Ministry of Social Development - Te Manatū Whakahiato Ora. Ministry of Social Development. doi:https://www.msd.govt.nz/documents/about-msd-and-our-work/publicationsresources/corporate/annual-report/2019-2020/msd-2019-20-annual-report.pdf Ministry of Social Development. (2020 (d), Nov ). Social sector accreditation standards. Retrieved Dec 13, 2020, from Ministry of Social Development: https://www.msd.govt.nz/documents/what-we-can-do/providers/social-servicesaccreditation/social-sector-accreditation-standards/social-sector-accreditation-standardslevel-2.pdf

Ministry of Social Development. (n.d.). About us and our work. Retrieved Dec 23, 2019, from Ministry of Social Development: https://msd.govt.nz/about-msd-and-our-work/index.html Mitchell, L. (2009, May). Te oranga o te Iwi Māori: A study of Maori economic and social progress. Retrieved Feb 9, 2019, from The New Zealand Initiative: https://nzinitiative.org.nz/reportsand-media/reports/te-oranga-o-te-iwi-maori-working-paper-5-maori-and-welfare/ 
Moewaka Barnes, H. (2000). Collaboration in community action: A successful partnership between indigenous communities and researchers. Health Promotion International, 15, 17-25.

Moewaka Barnes, H., \& McCreanor, T. (2019). Colonisation, hauora and whenua in Aotearoa. Journal of the Royal Society of New Zealand, 49(1), 19-33. doi:10.1080/03036758.2019.1668439

Moon, P. (2009). A chequered renaissance: The evolution of Māori society, 1984-2004. Te Kaharoa, 2, 23-41. doi:10.24135/tekaharoa.v2i1.123

Moorefield, J. C. (2003-2019). Māori Dictionary. Retrieved Apr 4, 2018, from Te Aka Māori-English, English-Māori Dictionary and Index: https://maoridictionary.co.nz/

Moorfield, J. C. (2003-2019). Māori dictionary online. Retrieved November 9, 2019, from Māori dictionary online: https://maoridictionary.co.nz/search?idiom=\&phrase=\&proverb=\&loan=\&histLoanWords= \&keywords=whakanoa

Morris, G., \& Alexander, K. (2017). Inclusiveness or tokenism? Culture and mediation in New Zealand's dispute resolution statutory regimes. 28 ADRJ 170. Retrieved Apr 3, 2021, from https://papers.ssrn.com/sol3/papers.cfm?abstract_id=3258090

Morrow, D. (2014). Tradition and modernity in discourses of Māori urbanisation. Journal of New Zealand Studies(18), 85-105. Retrieved October 20, 2019, from https://ojs.victoria.ac.nz/jnzs/issue/view/210

Mutu, T. (2014, November 23). Newsmaker: Takarua Mutu. Retrieved November 9, 2019, from New Zealand Herald: https://www.nzherald.co.nz/rotorua-dailypost/lifestyle/news/article.cfm?c_id=1503432\&objectid=11362519

Nemutandani, S. N., Hendricks, S. J., \& Mulaudzi, M. F. (2018). Decolonising the mindsets, attitudes and practices of the allopathic and indigenous health practitioners in postcolonial society: An exploratory approach in the management of patients. African Journal of Primary Health Care \& Family Medicine, 10(1), e1-e8. doi:10.4102/phcfm.v10i1.1518

New Zealand Association of Counsellors. (n.d. (a)). Code of ethics. Retrieved November 27, 2019, from New Zealand Association of Counsellors - Te Roopu Kaiwhiriwhiri o Aotearoa: New Zealand Association of Councellors - Te Roopu Kaiwhiriwhiri o Aotearoa

New Zealand Association of Counsellors. (n.d. (b)). Competencies. Retrieved from New Zealand Association of Counsellors - Te Roopu Kaiwhiriwhiri o Aotearoa: http://www.nzac.org.nz/competencies.cfm 
New Zealand Association of Counsellors. (n.d. (c)). Objectives. Retrieved 2019, from New Zealand Association of Counsellors - Te Roopu Kaiwhiriwhiri o Aotearoa: http://www.nzac.org.nz/objectives.cfm

New Zealand Association of Counsellors. (n.d. (d)). Philosophy. Retrieved November 27, 2019, from New Zealand Association of Counsellors: http://www.nzac.org.nz/viewobj.cfm/nzac_philosophy.pdf?file_name=nzac_philosophy.pd f\&objID=1587

New Zealand Government. (2019 (e), October). Social sector accreditation standards level 2. Retrieved November 2017, 2019, from Ministry of Social Development - Te Manatū Whakahiato Ora: https://www.msd.govt.nz/documents/what-we-can-do/providers/socialservices-accreditation/social-sector-accreditation-standards/social-sector-accreditationstandards-level-2.pdf

New Zealand History. (2018, May 10). The 1980s Page 2 Overview. Retrieved October 20, 2019, from New Zealand History: https://nzhistory.govt.nz/culture/the-1980s/overview

New Zealand Police. (2018, Jun 1). Haere rā, Viv. Retrieved Mar 7, 2021, from New Zealand Police: https://www.police.govt.nz/news/ten-one-magazine/haere-r\%C4\%81-viv

New Zealand Productivity Commission. (2015, August). More effective social services. Retrieved September 30, 2019, from New Zealand Productivity Commission: https://www.productivity.govt.nz/assets/Documents/8981330814/Final-report-v2.pdf

Newbold, G. (2007). The problem of prisons: Corrections reform in New Zealand since 1840. Wellington: Dunmore Publishing Ltd.

Newstalk ZB. (2019, Mar 15). Children's Commissioner weighs in on state care abuse: 'Deeply disturbing, utterly unacceptable'. Retrieved Oct 30, 2019, from Newstalk ZB: https://www.newstalkzb.co.nz/on-air/mike-hosking-breakfast/audio/childrenscommissioner-weighs-in-on-state-care-abuse-deeply-disturbing-utterly-unacceptable/

Ngata, W. (2017). Kanohi ki te kanohi: Face-to-face in digital space. He Whare Hangarau Māori: Language, Culture \& Technology, 178-183. Retrieved Feb 14, 2021

Nsiah-Gyabaah, K. (2003, October 16-18). Urbanization, environmental degradation and food security in Africa. Retrieved October 20, 2019, from Socioeconomic Data and Applications Centre: https://sedac.ciesin.columbia.edu/openmtg/docs/Nsiah-Gyabaah.pdf

O'Brien, M., Sanders, J., \& Tennant, M. (2009). The New Zealand non-profit sector and government policy. Wellington, New Zealand: Office for the Community and Volutary Sector. Retrieved 
Mar 14, 2021, from https://thehub.swa.govt.nz/resources/the-new-zealand-non-profitsector-and-government-policy/

Office of the Auditor General. (2012, August). Part 3: Historical and current context for Māori education. Retrieved October 20, 2019, from Controller and Auditor General: https://www.oag.govt.nz/2012/education-for-maori/part3.htm\#content Office of the Children's Commissioner. (2020). Te Kuku O Te Manawa - Moe ararā! Haumanutia ngā moemoeā a ngā tūpuna mō te oranga ngā tamariki. Retrieved Jan 21, 2021, from https://www.occ.org.nz/assets/Uploads/Te-Kuku-O-Te-Manawa-Report-2-OCC.pdf Office of Treaty Settlements. (2015, Mar). Ka tika à muri, ka tika ā mua. Retrieved Oct 2019, 30, from Ngati Rangitihi: https://ngatirangitihi.iwi.nz/wp-content/uploads/2017/06/The-RedBook-Healing-the-past-building-a-future.pdf

Ongley, P. (2013). Work and inequality in neoliberal New Zealand. New Zealand Sociology, 28(3), 136-163.

Oranga Tamariki. (2017). Ministry for Vulnerable Children Oranga Tamariki Strategic Intentions 2017 - 2022. Retrieved Feb 27, 2020, from Oranga Tamariki: https://www.orangatamariki.govt.nz/assets/Uploads/Publications/Strategicintentions/Strategic-Intentions-2017-2022.pdf

Oranga Tamariki. (2018, Dec 14). Statistics on children in state care. Retrieved Feb 8, 2020, from Oranga Tamariki: https://www.orangatamariki.govt.nz/assets/Uploads/20181214Statistics-on-Children-in-State-Care.pdf

Oranga Tamariki. (2020, Apr 20). Section 7AA quality assurance standards. Retrieved Dec 5, 2020, from Oranga Tamariki: https://orangatamariki.govt.nz/about-us/reports-andreleases/section-7aa/section-7aa-quality-assurance-standards/

Parata, H. (1994). Mainstreaming: A Māori Affairs policy? Social Policy Journal of New Zealand(3), 40-51.

Patea, H. (2019, May 10). Ministry of Social Development Principal Advisor Māori. (V. Underwood, Interviewer)

Pihama, L., Smith, K., Taki , M., \& Lee, J. (2004). A literature review on kaupapa Māori and Māori education pedagogy. Auckland: The International Research Institute for Maori and Indigenous Education. Retrieved Apr 3, 2021, from https://www.researchgate.net/publication/242681956_A_LITERATURE_REVIEW_ON_KAUP APA_MAORI_AND_MAORI_EDUCATION_PEDAGOGY 
Pipi, K., Cram, F., Hawke, R., Hawke, S., Huriwai, T., Keefe, V., . . Tuuta, C. (2002). Iwi and Māori provider success: A research report of interviews with successful Iwi and Māori providers and government agencies. Wellington: Te Puni Kōkiri. Retrieved Feb 2021, 6, from http://www.communityresearch.org.nz/research/iwi-and-maori-provider-success-aresearch-report-of-interviews-with-successful-iwi-and-maori-providers-and-governmentagencies/

Pohatu, T. W. (2013). Āta: Growing respectful relationships. Ata: Journal of Psychotherapy Aotearoa New Zealand, 17(1), 13-26.

Rabe, M. (2003). Revisiting 'insiders' and 'outsiders' as social researchers. African Sociological Review, 7(2), 149-161.

Rakena, R. R. (1961, Mar 25). Some comments on the Hunn report on Maori Affairs. New Zealand Methodist Times, p. 633.

Rameka, L. (2016). Kia whakatōmuri te haere whakamua: 'I walk backwards into the future with my eyes fixed on my past'. Contemporary Issues in Early Childhood, 17(4), 387-398. doi:10.1177/1463949116677923

Reid , J., Rout, M., Tau, T., \& Smith, C. (2017). The colonising environment: An Aetiology of the trauma of settler colonisation and land alienation on Ngāi Tahu whānau. Christchurch, New Zealand: University of Canterbury Ngāi Tahu Research Centre.

Rewi, P. (2010). Karakia Māori: Māori invocations to spiritual authorities. He Pukenga Kōrero, 9(2), 15-20. Retrieved Dec 10, 2020, from http://www.hepukengakorero.com/index.php/HPK/article/viewFile/3/pdf

Ringold, D. (2005). Accounting for diversity: Policy design and Māori. Retrieved Jan 24, 2021, from FulBright New Zealand: https://www.fulbright.org.nz/wpcontent/uploads/2011/12/axford2005_ringold.pdf

Ross, R. (1972). Te Tiriti o Waitangi texts and translations. NZ Journal of History, 6, 129-157. Retrieved Oct 14, 2020, from http://www.nzjh.auckland.ac.nz/document.php?wid=1533\&action=null

Royal, T. A. (2005). Exploring indigenous knowledge. Proceedings of the Indigenous Knowledges Conference Reconciling Academic Priorities with Indigenous Realities, (pp. 133-148). [Paper presentation]. Wellington, New Zealand. Retrieved Mar 19, 2021, from http://www.maramatanga.co.nz/sites/default/files/TKC\%202005.pdf 
Royal, T. C. (2007, Sep 24). Te Waonui a Tāne: Forest mythology - Symbolism of trees and plants. Retrieved Jun 16, 2019, from Te Ara Encyclopedia: https://teara.govt.nz/en/diagram/13162/harakeke-plant

Ruru, S., Roche, M., \& Waitoki, W. (2017). Māori women's perspectives of leadership and wellbeing. The Journal of Indigenous Wellbeing, 2(1), 5-14.

Sibley, C. G., \& Houkamau, C. A. (2013). The multi-dimensional model of Māori identity and cultural engagement: Item response theory analysis of scale properties. Cultural Diversity and Ethnic Minority Psychology, 19(1), 97-110. doi:https://doi.org/10.1037/a0031113

Siliunas, A., Small, M. L., \& Wallerstein, J. (2019). We can help, but there's a catch; Nonprofit organizations and access to government-funded resources among the poor. Journal of Organizational Ethnography, 8(1), 109-128. doi:https://doi.org/10.1108/JOE-04-2018-0018

Simons, H. (2009). Case study research in practice. Sage Publications Ltd. doi:https://doi.org/10.4135/9781473920156

Smith, G. H. (1997). The development of Kaupapa Māori: Theory and praxis. Doctoral dissertation, Faculty of Education. University of Auckland, New Zealand.

Smith, G. H. (2017). Kaupapa Māori theory: Indigenous transforming of education. In T. Hoskins, T. Hoskins, \& A. Jones (Eds.), Critical Conversations in Kaupapa Māori. Wellington, New Zealand: Huia Publishers.

Smith, J. (2010). Biculturalism and multiculturalism: Competing tensions in visual arts education in Aotearoa-New Zealand. International Journal of Multicultural Education, 12(2), 1-18. doi:10.18251/ijme.v12i2.319

Smith, L. T. (1999). Decolonizing methodologies: Research and indigenous peoples. New York \& Dunedin: Zed Books \& Otago University Press.

Smith, L. T. (2006 (a)). Decolonizing Methodologies: Research and Indigenous Peoples (Ninth impression ed.). London \& New York: Zed Books Ltd.

Smith, L. T. (2006 (b)). Researching in the margins: Issues for Māori researchers - A discussion paper. Alternative: An International journal of Indigenous Peoples, 2(1), 4-27.

Social Workers Registration Board. (2021 (a)). Social workers step into mandatory registration. Retrieved Apr 2021, 13, from Social Workers Registration Boards: https://swrb.govt.nz/step-into-mandatory-registration/ 
Social Workers Registration Board. (2021 (b)). Tiwhikete mahi: Practising certificate. Retrieved Apr 13, 2021, from Social Workers Registration Board: https://swrb.govt.nz/practice/practisingcertificate/

Social Workers Registration Board. (n.d. (a)). Core competence standards. Retrieved November 25, 2019, from Social Workers Registration Board: https://swrb.govt.nz/for-socialworkers/core-competence-standards/

Social Workers Registration Board. (n.d. (b)). Mandatory registration. Retrieved November 25, 2019, from Social Workers Registration Board: https://swrb.govt.nz/aboutus/legislation/mandatory-registration/

Statistics New Zealand. (2008). Household labour force survey (1986-2007). Wellington: statistics New Zealand.

Statistics New Zealand. (2017, Feb 7). Māori unemployment rate at nine-year low, but twice New Zealand rate. Retrieved Jan 20, 2020, from Statistics New Zealand: https://www.stats.govt.nz/news/maori-unemployment-rate-at-nine-year-low-but-twicenew-zealand-rate

Sutherland, O. (2020). Justice \& Race: Campaigns against racism and abuse in Aotearoa New Zealand. Petone: Steele Roberts Aotearoa Publishers.

Swain, D. A. (1987). Children, families, law and social policy in Aotearoa/New Zealand. Journal of Comparative Family Studies, 18(2), 175-206. Retrieved Feb 14, 2021, from https://wwwjstor-

org.helicon.vuw.ac.nz/stable/pdf/41601455.pdf?refreqid=excelsior\%3A3d0a36814614e08 bd1adcce04463278d

Taki, M. (1996). Kaupapa Māori and contemporary Iwi resistance. [Unpublished M.A. thesis, Education Department]. University of Auckland, New Zealand.

Taonui, R. (2012, Jun 20). Te ture - Māori and legislation: Eva Rickard, Raglan land occupation, 1978. Retrieved Oct 30, 2019, from Te Ara - the Encyclopedia of New Zealand: https://teara.govt.nz/en/speech/36547/eva-rickard-raglan-land-occupation-1978

Taylor, J. (2011, Feb). The intimate insider: Negotiating the ethics of friendship when doing insider research. Qualitative Research Journal, 11(1), 3-22. doi:10.1177/1468794110384447

Te Arawhiti - The Office for Māori Crown Relations. (2018 (a), Oct 1). Crown engagement with Māori. Retrieved Mar 10, 2021, from Te Arawhiti - The Office for Māori Crown Relations: 
https://www.tearawhiti.govt.nz/assets/Tools-and-Resources/Crown-engagement-withMaori-Framework.pdf

Te Arawhiti - The Office for Māori Crown Relations. (2019 (a), Mar). Māori Crown relations capability framework for the public service - Individual capability component. Retrieved Feb 28, 2021, from Te Arawhiti - The Office for Māori Crown Relations: https://www.tearawhiti.govt.nz/assets/Tools-and-Resources/Maori-Crown-RelationsCapability-Framework-Individual-Capability-Component.pdf

Te Arawhiti - The Office for Māori Crown Relations. (2019 (b), Mar). Māori Crown relations capability framework for the public service - Organisational capability component. Retrieved Feb 28, 2021, from Te Arawhiti - The Office for Māori Crown Relations: https://www.tearawhiti.govt.nz/assets/Tools-and-Resources/Maori-Crown-RelationsCapability-Framework-Organisational-Capability-Component.pdf

Te Arawhiti: The Office for Māori Crown Relations. (2018 (b), Oct 1). Guidelines for engagement with Māori. Retrieved Jan 30, 2020, from Te Arawhiti: The Office for Māori Crown Relations: https://tearawhiti.govt.nz/assets/Maori-Crown-RelationsRoopu/6b46d994f8/Engagement-Guidelines-1-Oct-18.pdf

Te Awekotuku, N. (1991). He tikanga whakaaro: Research ethics in the Māori community. Wellington, New Zealand: Manatu Māori.

Te Kohanga Reo National Trust. (n.d.). History. Retrieved October 30, 2019, from Te Kohanga Reo National Trust: https://www.kohanga.ac.nz/history/

Te Momo, O. H. (2015). Māori social work. (J. D. Wright, Ed.) International Encyclopedia of the Social \& Behavioral Sciences (Second Edition), 14, 505-511. doi:https://doi.org/10.1016/B978-0-08-097086-8.28054-9

Te Puni Kōkiri. (2015). Understanding whānau-centred approaches. Te Puni Kokiri. Retrieved Feb 21, 2021, from https://www.tpk.govt.nz/en/a-matou-mohiotanga/whanauora/understanding-whanaucentred-approaches-analysis-of

Te Puni Kōkiri. (2018 (a), October). He Takunetanga Rautaki 2018-2022: Strategic Intentions 20182022. Retrieved September 14, 2019, from Te Puni Kōkiri: https://www.tpk.govt.nz/documents/download/4705/tpk-strategic-intentions-2018.pdf Te Puni Kōkiri. (2018 (b), December 20). Role and Functions. Retrieved November 9, 2019, from Te Puni Kōkiri: https://www.tpk.govt.nz/en/mo-te-puni-kokiri/what-we-do/our-role-andfunctions 
Te Puni Kōkiri. (2019, September 15). History. Retrieved October 19, 2019, from Te Puni Kōkiri: https://www.tpk.govt.nz/en/mo-te-puni-kokiri/who-we-are/history

Te Rau Matatini [Te Rau Ora Webinars]. (2017, Aug 14). Tikanga Rangahau Webinar Series Kaupapa Māori Methodology. YouTube. https://www.youtube.com/watch?v=w3aSsvLFsT4\&ab_channel=TeRauOraWebinars.

The Accident Compensation Corporation. (2018). Statement of Intent 2018 - 2022. Retrieved Feb 27, 2020, from The Accident Compensation Corporation: https://www.acc.co.nz/assets/corporate-documents/f23bf80b2d/acc7849-statement-ofintent-2018-2022.pdf

The Department of Corrections. (2018). Statement of Intent 2018 - 2022. Retrieved Feb 27, 2020, from The Department of Corrections: https://www.corrections.govt.nz/_data/assets/pdf_file/0015/33144/Statement_of_Inten t_SOI_Final_18-22.pdf

The Reserve Bank of New Zealand. (2007). The Reserve Bank and New Zealand's Economic History. Retrieved August 17, 2019, from The Reserve Bank of New Zealand: https://www.rbnz.govt.nz//media/ReserveBank/Files/Publications/Factsheets\%20and\%20Guides/factsheet-thereserve-bank-and-nzs-economic-history.pdf

The Waitangi Tribunal. (1986). Report of the Waitangi Tribunal on the Te Reo Maori claim (Wai 11). Wellington: Government Printer. Retrieved October 20, 2019, from https://forms.justice.govt.nz/search/Documents/WT/wt_DOC_68482156/Report\%20on\%2 Othe\%20Te\%20Reo\%20Maori\%20Claim\%20W.pdf

Thomas, D. R., \& Nikora, L. W. (1992). From assimilation to biculturalism: Changing patterns in Māori-Pakeha relationships. In D. R. Thomas, \& A. Veno (Eds.), Community Psychology and Social Change: Australian and New Zealand perspectives. Palmerston North: Dunmore.

Thomas, G., \& Myers, K. (2015). The anatomy of the case study. SAGE Publications Ltd. doi:https://doi.org/10.4135/9781473920156

Tolerton, J. (2010, Mar 11). Agricultural processing industries - Meat processing from 1970s. Retrieved Oct 20, 2019, from Te Ara - the Encyclopedia of New Zealand: https://teara.govt.nz/en/agricultural-processing-industries/page-8

Tolich, M. (2002). Pākehā 'paralysis': Cultural safety for those researching the general population of Aotearoa. Social Policy Journal of New Zealand, 19, 164-178. 
Turia, T. (2000). Closing the Gaps. [Speech transcript]. Retrieved Apr 23, 2021, from https://www.beehive.govt.nz/speech/closing-gaps

Tūtira Mai NZ. (n.d.). Māori culture and tikanga practices for the workplace. Retrieved Apr 11, 2021, from Tūtira Mai NZ:

https://static1.squarespace.com/static/587c135515d5db2c4baeab05/t/5c109fd2758d46e1 5e67fe0b/1544593445337/M\%C4\%81ori+Culture+and+Tikanga+Practices+for+the+Workpl ace+-+T\%C5\%ABtira+Mai+NZ.pdf

Underwood, V. (2019, August 15). Factsheet: Trends of influence of change. Lower Hutt, New Zealand: Wellstop.

Underwood, V., \& Robin-Underwood, S. (2015). Welcome to WellStop. Retrieved Jan 8, 2020, from WellStop: https://www.wellstop.org.nz/

Victoria University of Wellington: Te Herenga Waka. (n.d.). Tikanga tips. Retrieved Jan 24, 2021, from Victoria University of Wellingon: https://www.wgtn.ac.nz/maori-hub/ako/teachingresources/tikanga-tips

Waikato Regional Council. (2017, Oct). Māori engagement framework. Retrieved Dec 10, 2020, from Waikato Regional Council: https://www.waikatoregion.govt.nz/assets/WRC/Council/Policy-and-Plans/11340016Maori-Engagement-Framework-Guide.pdf

Walker, R. J. (1984). The genesis of Māori activism. The Journal of the Polynesian Society, 93(3), 267-281.

Weible, C. M. (2018). Introduction: The scope and focus of policy process research and theory. In C. M. Weible, \& P. A. Sabatier (Eds.), Theories of the Policy Process (pp. 1-13). doi:https://doi.org/10.4324/9780429494284

Weible, C. M., \& Sabatier, P. A. (2018). Theories of the policy process (4th ed.). New York: Taylor \& Francis Group. doi:https://doi.org/10.4324/9780429494284

Welfare Expert Advisory Group. (2018, Jul). A brief history of family support payments in New Zealand. Retrieved Nov 23, 2019, from Welfare Expert Advisory Group: http://www.weag.govt.nz/assets/documents/WEAG-report/backgrounddocuments/133db2ad05/History-of-family-support-payments-010419.pdf

Welfare Expert Advisory Group. (n.d.). Our welfare system. Retrieved November 9, 2019 (1), from Welfare Expert Advisory Group: http://www.weag.govt.nz/assets/documents/have-yoursay/2e163bc71f/statistics.pdf 
WellStop. (n.d. (a)). Community engagement. Retrieved November 9, 2019, from WellStop: https://www.wellstop.org.nz/community-and-partnerships.html

WellStop. (n.d. (b)). Our story. Retrieved November 9, 2019, from WellStop: https://www.wellstop.org.nz/our-story.html

WellStop. (n.d. (c)). Service locations. Retrieved November 9, 2019, from Wellstop: https://www.wellstop.org.nz/service-locations.html

WellStop. (n.d. (d)). Welcome to WellStop. Retrieved Jun 20, 2019, from Wellstop: https://www.wellstop.org.nz/

Wihongi, H. A. (2010). Tino rangatiratanga in health policies and practises. [Doctoral Thesis, University of Waikato].

Williams, D. V. (2019). The continuing impact of amalgamation, assimilation and integration policies. Journal of the Royal Society of New Zealand, 49(S1), 34-47. doi:https://doi.org/10.1080/03036758.2019.1677252

Williams, R. T. (2013). Examine your lens: A tool for interpreting cultural differences. Frontiers The Interdisciplinary Journal of Study Abroad, 22(1), 148-165. doi:10.36366/frontiers.v22i1.324

Willis, R. (1994, November). Ten years of change in New Zealand manufacturing employment. Labour, Employment and Work in New Zealand, [S.I.], ISSN 2463-2600, 344-355. Retrieved Nov 21, 2019, from Open Journal Systems at Victoria University of Wellington Library: https://ojs.victoria.ac.nz/lew/article/download/944/757

Xanthaki, A., \& O'Sullivan, D. (2009). Indigenous participation in elective bodies: The Māori in New Zealand. International Journal on Minority and Group Rights, 181-207.

Xu, X. (2016). Researchers' positioning: Insider or outsider? The Morning Watch: Educational and Social Analysis, 44(1-2 Fall). Retrieved Feb 7, 2021, from https://journals.library.mun.ca/ojs/index.php/mwatch/issue/view/124

Zahariadis, N. (2005). Essence of political manipulation: Emotion, institutions, \& Greek foreign policy (Illustrated ed.). New York, USA: Peter Lang Publishing. 


\section{Appendices}

\section{Appendix A: Consent to participate form (organisations)}

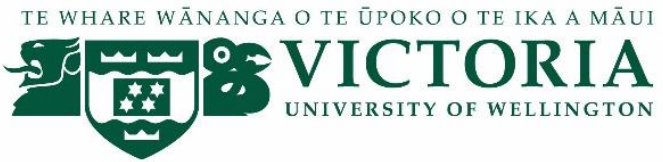

The Creation and Implementation of Māori Policies

CONSENT TO PARTICIPATE (ORGANISATION)

This consent form will be held until 1 June 2020 .

Researcher: Vincent Underwood, School of Social and Cultural Studies, Victoria University of Wellington.

- I have read the Information Sheet and the project has been explained to me. My questions have been answered to my satisfaction. I understand that I can ask further questions at any time.

- I agree that my organisation will take part.

I understand that:

- I may withdraw this organisation from this study at any point before 1 July2019, and the information provided by members of the organisation will be returned to them/or destroyed

- I understand that the results will be used for a Masters thesis and may be used for academic publications and presented to conferences. 
- I consent to information or opinions which are given by the participants being attributed to the organisation in any Yes No reports on this research and have the authority to agree to this on behalf of the organisation.

- I would like to receive a copy of the final report and have Yes No added my email address below.

Signature of Organisation Authority:

Name of Authorised Person:

Date:

Contact details: 


\section{Appendix B: Consent to interview (participants)}

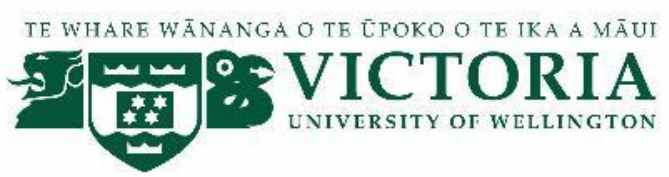

The Creation and Implementation of Māori Policies

CONSENT TO INTERVIEW

This consent form will be held until 1 June 2020 .

Researcher: Vincent Underwood, School of Social and Cultural Studies, Victoria University of Wellington.

- I have read the Information Sheet and the project has been explained to me. My questions have been answered to my satisfaction. I understand that I can ask further questions at any time.

- I agree to take part in an audio recorded interview.

I understand that:

- I may withdraw from this study at any point before 1 July 2019, and any information that I have provided will be returned to me or destroyed.

- The identifiable information I have provided will be destroyed on 1 June 2020.

- $\quad$ Any information I provide will be kept confidential to the researcher and the supervisor.

- I understand that the results will be used for a Masters thesis and may be used for academic publications and presented to conferences. 
- I consent to information or opinions which I have given being attributed to me in any reports on this research: Yes No

- I would like a copy of the recording of my interview: Yes No

- I would like a copy of the transcript of my interview: $\begin{array}{ccc}\square & \square \\ \text { Yes } & \text { No }\end{array}$

- I would like to receive a copy of the final report and have Yes No added my email address below.

Signature of participant:

Name of participant:

Date:

Contact details: 


\section{Appendix C: Interview questions}

\section{Interview Questions:}

\section{History}

Please give a description of who you are and where you come from (Pepeha)?

What experience do you have in social policy?

\section{Hui tīkanga - protocol used in meetings}

What consultation process and schedule was deemed important in the formation of these policies?

How many meetings/hui took place to form your policies?

Who were the targeted audience for these meetings/hui?

Where were the meetings held?

\section{Participants involved/organisations}

Were hapū and Iwi engaged within the decision-making process?

What consultation process was used to engage with clients/customers/whānau in the formation of these policies? 
What consultation process was used to engage with other agencies/Ministries e.g. Te Puni Kōkiri?

\section{Tīkanga - application to policy}

Explain the value of utilising Tikanga within the establishment process?

What challenges did you face blending Māori knowledge within social policy?

What Tikanga process of engagement was used within the meetings/hui?

Why were these Tikanga processes used above others?

Was there any wairua (holistic ritual) processes utilised?

Why were these rituals used?

\section{Journey/process of approval}

What process was used to gain approval?

Who was involved in the approvals process?

Who were deemed stakeholders?

Who were deemed the respective recipients? (Who were the targeted audience?)

Te Reo - Language 
What process was used to validate the use of language?

What consultation took place to ensure the efficacy of the terms and meanings included in the policies? e.g. Whakataukī/saying, origin of the names, Iwi dialects 
Appendix D: Our strategy - our voice (Whānau)

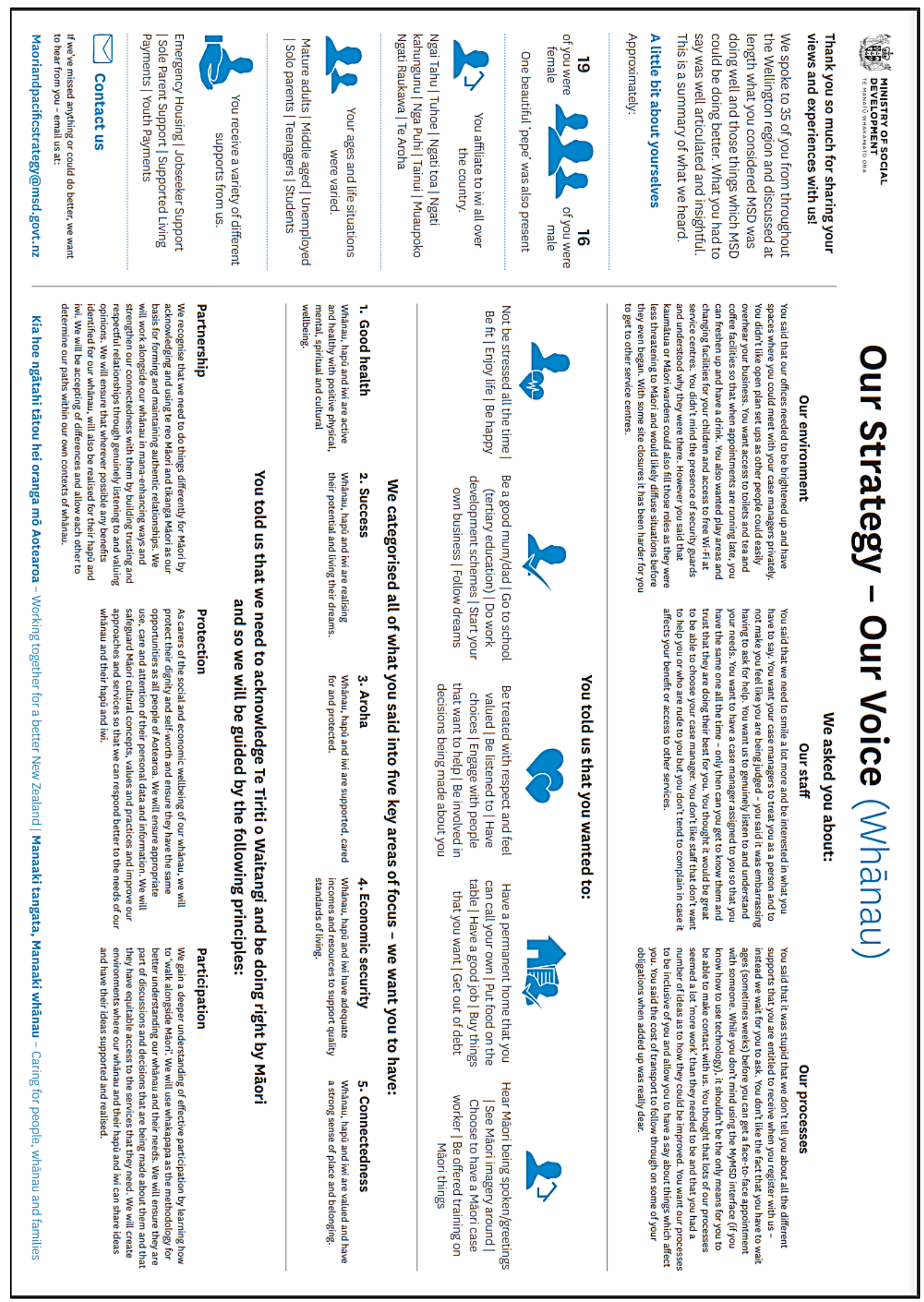




\section{Appendix E: Our strategy - Our voice (Providers)}

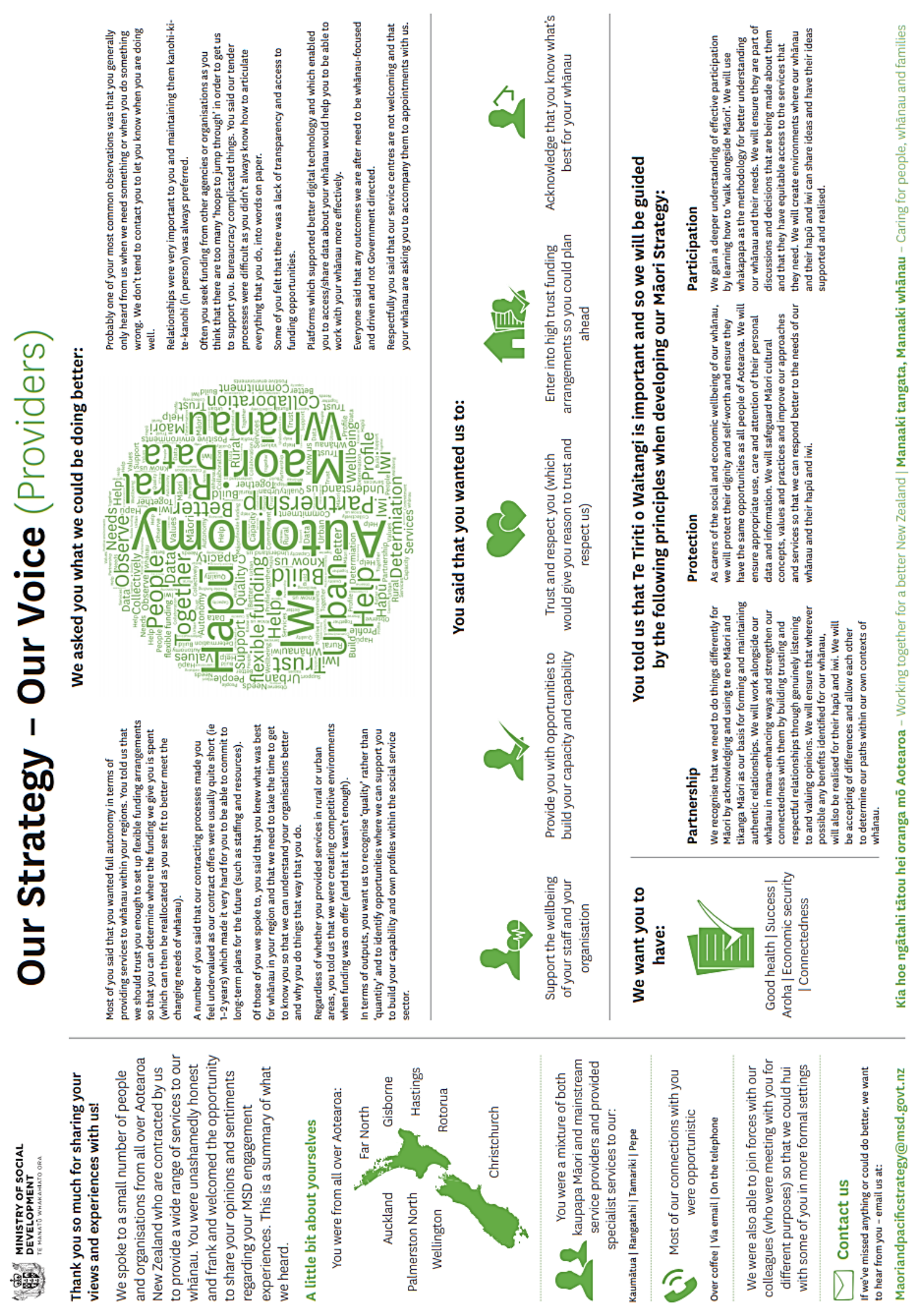


Appendix F: Our strategy - our voice (Staff)

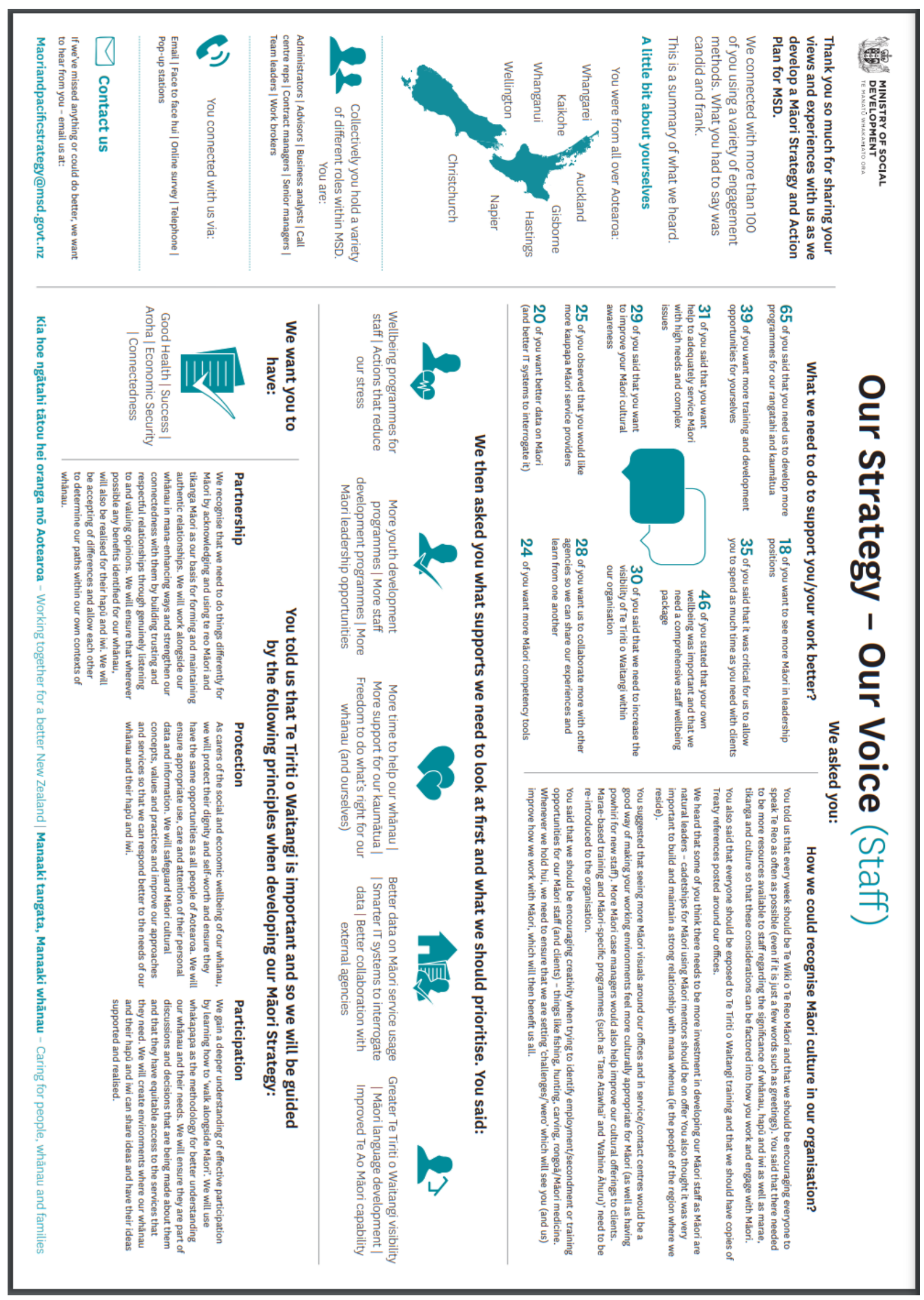




\section{Appendix G: Karakia mō te whakawātea o WellStop}

Mo ngā tāngata i kimi i nga whakautu, hei ahei ia tātou ki te whiwhi i te pono Let them who seek answers find the truth

Mo nga tangata i kimi i nga whakautu, hei ahei ia tātou ki te whiwhi i te pono Let them who are weary in heart, Mind, Spirit, Body find rest here

Mo nga tangata I tino ngenge I ta tatou ngakau, hinengaro, wairua, tinana hoki hei ahei tatou ki te whiwhi I te okioki nei

Let the Journey of those in this place be one of peace, forgiveness, empowerment

Hei ahei te haerenga o tatou I tenei wahi he haerenga i te rangimarie, whakamurua, whakamana hoki

May this place be seen as a Waka Huia a place where all are Treasured and Protected

Hei ahei I tenei wahi ka kite I tetahi wahi i orite ki te wakahuia. He wahi kia whakapoho, whakatiaki I a tatou katoa

May all seeds find good earth and the seedlings prosper and the tree stand like the mighty Totara

hei ahei I nga kakano ki te kimihia I te oneone pai rawa, te pihinga ki te makuru, te rakau ki te tu I orite ki te totara kaiora

Help the roots grow deep, strong, steadfast, resiliant

Hei awhina i nga pakiaka ki te rea hohonu, marohirohi, aumangea hoki

May this tree be regarded/ honoured for the strength of its countenance.

Hei ahei $\mathrm{i}$ te honore ki te rakau nei na te mea o te marohirohi o tana ahua

Tuturu Whakamaua ki a tina, tina haumi e hui e taieke e

Honour the tree for the strength of its countenance 
Tūturu whakamaua, kia tina. Tina!

Haumi ē Hui ē, Tāiki e! 


\section{Appendix H: WellStop Kaiārahi Māori Progress Report}

\section{Kaiārahi Māori Progress report:}

From before the $1^{\text {st }}$ July and beyond the space where Māori Staff have occupied has grown. The following represents kakano seeds that have been planted and the seedlings pihinga that have appeared to create WellStop into the Majestic Totara. This is not work completed in isolation as many hands have assisted in the journey and now in the Kaiārahi Māori role. All strategies from a Māori perspective is driven from this role.

Māori based policy, staff training to the partnership in the sector

\section{Implemented}

The following outlines what has been achieved from 1 July and January 2020, this follows on from the implementation plan for Māori engagement and responsiveness.

\begin{tabular}{|c|c|c|}
\hline Well & ector & $\mathbf{w i}$ \\
\hline $\begin{array}{l}\text { It is vital to create a Māori voice } \\
\text { in the mahi } \\
\text { - Create share point } \\
\text { presence } \\
\text { - Create an accessible line } \\
\text { of communication } \\
\text { - Send out introduction } \\
\text { email } \\
\text { - Management meeting } \\
\text { orientation and presence } \\
\text { - Establish a Māori staff } \\
\text { line of communication, to } \\
\text { awhi Māori staff } \\
\text { - } \text { Placement supervision } \\
\text { Kaye's registration } \\
\text { support } \\
\text { Case consultation }\end{array}$ & $\begin{array}{l}\text { Engage with safe and } \\
\text { stop (Trinity Group) } \\
\text { • Staff survey } \\
\text { - Create further } \\
\text { lines of } \\
\text { communication } \\
\text { possibly a } \\
\text { monthly forum } \\
\text { Skype or zoom } \\
\text { chat } \\
\text { Opportunity to build } \\
\text { closer bonds with the } \\
\text { project team also an } \\
\text { opportunity to share } \\
\text { advise of processes } \\
\text { used. }\end{array}$ & $\begin{array}{l}\text { First introductions: } \\
\text { Main Iwi in Wellington } \\
\text { Rangitane } \\
\text { Te Atiawa } \\
\text { Ngati toa } \\
\text { - Engagement } \\
\text { - Main contact people } \\
\text { (Directory) } \\
\text { - After the immediate } \\
\text { introductions }\end{array}$ \\
\hline
\end{tabular}




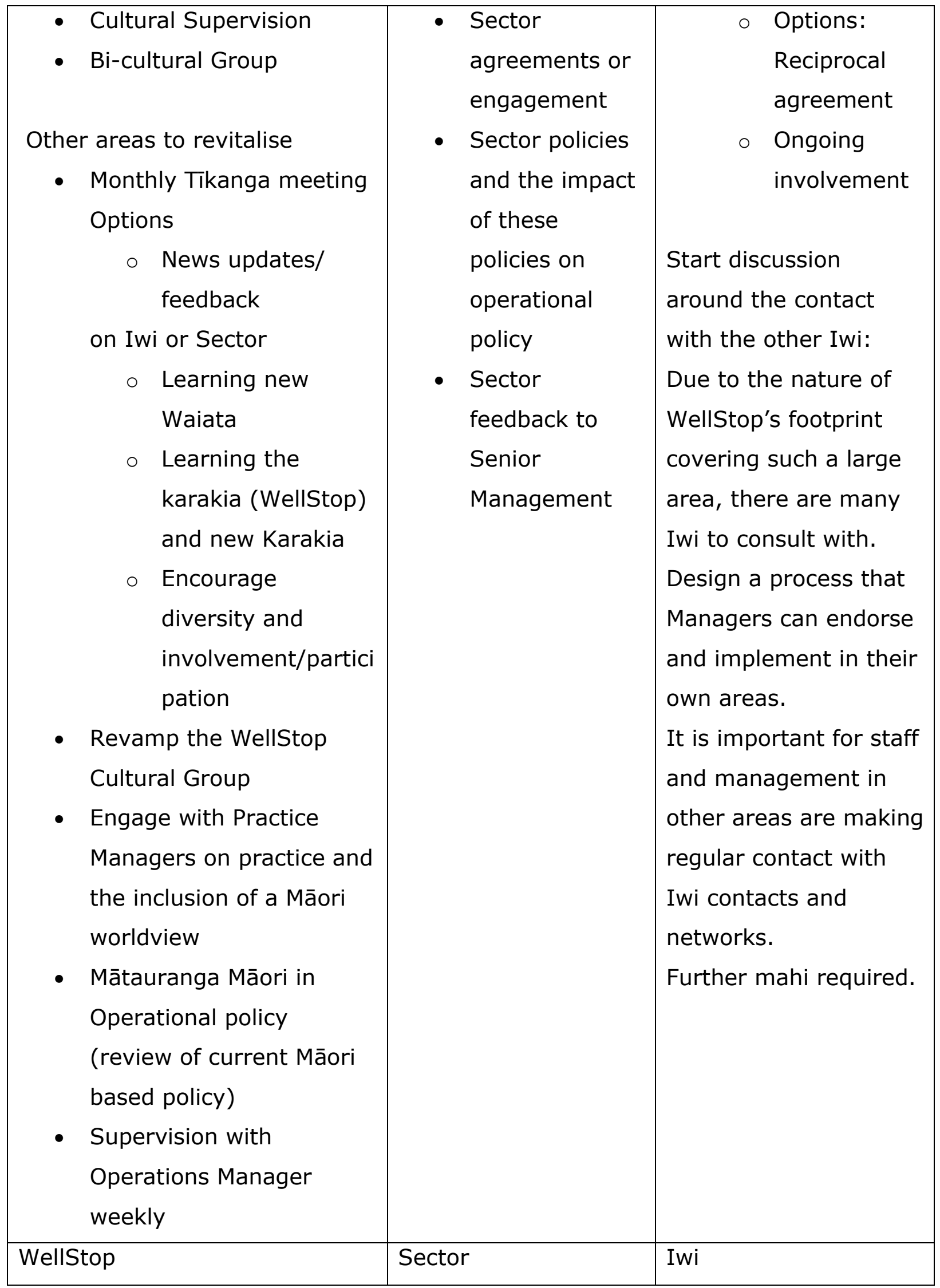




\begin{tabular}{|l|l|l|}
\hline Kaupapa nui: & Kaupapa nui: & Kaupapa nui: \\
Seek ways to engage with staff & Seek ways to engage & Seek ways to engage \\
Seek ways to engage with & with the Sector Team & with Iwi \\
Management & Seek ways to & Seek ways to feedback \\
Seek ways to engage with team & feedback with & with Management \\
leaders & Management & Seek ways to feedback \\
Training and development of & Seek ways to & with staff \\
Staff from a mātauranga base & feedback with staff & \\
of training and resources & Offer advice on & \\
& mātauranga Māori & \\
& principles & \\
\hline
\end{tabular}

Engagement with staff

- Increased the number of group workshop-based learning

- Tapū and Noa

- Karakia WellStop

- Māori Arts

- Te Reo

- Māori Language week

- Changes coming there is discussion about having the sessions changed to the professional hour and the tīkanga hour, it was discussed with staff that these times best suits, Lesley and Mark consulted, and we have their support. I will be implementing this when I return from annual leave

- Regions: I have run group sessions with each office and am organising a monthly workshop session per region.

Concern from the regions: They are asking that I with Mark visit their offices to whanaungatanga and kanohi ki te kanohi

- Increased participation and willingness of staff to learn, staff have indicated the value of the sessions and they have suggested better times as they wish to attend, they see the value of this mahi.

- Cultural Supervision: Currently 5 staff are being culturally supervised by me, the reasons for supervision are varied. I understand that the need 
for cultural supervision is required for professional registration. I do have an open-door policy and the use of this has increased where I have spoken to all of the clinical staff at some point over the last couple of months.

- Case Consultation with Clinicians/staff we Māori whānau: This has increased, discussing the implementation of tīkanga in practice to consulting on values and principles. To consulting on the implementation of the teen group in which I am participating and facilitating several sessions. This mahi will continue to increase.

- Sharepoint (Whiria te tangata) up and running and we have had many viewings of content, trying to maintain a steady feed of information for staff without going overboard. It has taken some time to embed the use of sharepoint as a first port of call. But we are getting more staff accessing the information

- Sharepoint news: I am active on sharing news articles to inform staff, creating further presence on sharepoint for staff.

- Pacific introducing new models and theories to inform staffs practice. I will be sourcing more and more pacific information for staff and will aim to get some speakers in to kōrero about their area of expertise.

- Forming the Māori competency (staff consultation will happen through the bi-cultural group)

This is still a work in process. I have formed a starting place, but I feel I need to consult with staff on this, I have chosen to utilise the bi-cultural group as my staff filter for this information.

Bicultural Group

- I have taken the lead in this group, my first decision in consultation with Mark was to increase the numbers of participants, we have a person from each office, we have a great mix: Māori, Non-māori, Male, Female. This diverse group places WellStop in a position to get a cross section perception of voices which will contribute to the creation of our Tikanga (truth).

As this group also represents the regions, we can disseminate information and gain insight that benefits our processes. 
- I am an active member of the senior management team and contribute on Māori issues and advise on issues pertaining cultural practice, recently working alongside the Practice Manager on Professional Registration and alongside the HR Manager of WellStop's Values and Competencies, Mark with the Sector group

Engagement with the Sector - Trinity Group

- Participated in a meeting with our regional partners (Safe and Stop)

- Completed the development of the Sector Māori Responsiveness survey and these results will be sent to our partners

- I have been tasked with analysing the sector survey data and report on the findings

- Maintain relationships

Engagement with Iwi

- I have completed whanaungatanga with Ngati toa, Te Atiawa and Rangitane

- Mark was present when we meet with Rangitane

- Maintenance of these relationships is needed

New Areas of influence:

Accreditation level 2 review (MSD) and Cultural Competency

- I have reviewed all the competencies and will be discussing this further with the bi-cultural team.

- We are well into accomplishing each area, but more work required (ongoing)

Increased need for cultural supervision for registration and practice

- As mentioned, cultural supervision is increasing, the numbers are being managed by me

Sector Māori Responsiveness Survey completed

- This needs to be sent to Safe and Stop, we may need to meet to discuss the next step 
Te Pae Tata is now implemented and influences MSDs processes into the future

- I am working on Te Pae Tata for my thesis, so I am aware of this policy, it is in hand.

Training that development is a major task, I have decided to form elearning based models for the convenience of staff to access ongoing training when they are available" 